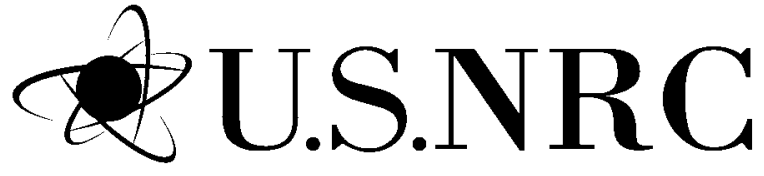

NUREG/CR-7106 ORNL/TM-2011/298

United States Nuclear Regulatory Commission

Protecting People and the Environment

\title{
Generation of a Broad- Group HTGR Library for Use with SCALE
}




\section{AVAILABILITY OF REFERENCE MATERIALS IN NRC PUBLICATIONS}

\section{NRC Reference Material}

As of November 1999, you may electronically access NUREG-series publications and other NRC records at NRC's Public Electronic Reading Room at http://www.nrc.gov/reading-rm.html. Publicly released records include, to name a few, NUREG-series publications; Federal Register notices; applicant, licensee, and vendor documents and correspondence; NRC correspondence and internal memoranda; bulletins and information notices; inspection and investigative reports; licensee event reports; and Commission papers and their attachments.

NRC publications in the NUREG series, NRC regulations, and Title 10, Energy, in the Code of Federal Regulations may also be purchased from one of these two sources.

1. The Superintendent of Documents

U.S. Government Printing Office

Mail Stop SSOP

Washington, DC 20402-0001

Internet: bookstore.gpo.gov

Telephone: 202-512-1800

Fax: 202-512-2250

2. The National Technical Information Service Springfield, VA 22161-0002

www. ntis.gov

1-800-553-6847 or, locally, 703-605-6000

A single copy of each NRC draft report for comment is available free, to the extent of supply, upon written request as follows:

Address: U.S. Nuclear Regulatory Commission

Office of Administration

Publications Branch

Washington, DC 20555-0001

E-mail: DISTRIBUTION.RESOURCE@NRC.GOV

Facsimile: 301-415-2289

Some publications in the NUREG series that are posted at NRC's Web site address

http://www.nrc.gov/reading-rm/doc-collections/nuregs

are updated periodically and may differ from the last printed version. Although references to material found on a Web site bear the date the material was accessed, the material available on the date cited may

subsequently be removed from the site.

\section{Non-NRC Reference Material}

Documents available from public and special technical libraries include all open literature items, such as books, journal articles, and transactions, Federal Register notices, Federal and State legislation, and congressional reports. Such documents as theses, dissertations, foreign reports and translations, and non-NRC conference proceedings may be purchased from their sponsoring organization.

Copies of industry codes and standards used in a substantive manner in the NRC regulatory process are maintained at-

The NRC Technical Library

Two White Flint North

11545 Rockville Pike

Rockville, MD 20852-2738

These standards are available in the library for reference use by the public. Codes and standards are usually copyrighted and may be purchased from the originating organization or, if they are American National Standards, from-

American National Standards Institute 11 West $42^{\text {nd }}$ Street

New York, NY 10036-8002

www.ansi.org

212-642-4900

Legally binding regulatory requirements are stated only in laws; NRC regulations; licenses, including technical specifications; or orders, not in NUREG-series publications. The views expressed in contractor-prepared publications in this series are not necessarily those of the NRC.

The NUREG series comprises (1) technical and administrative reports and books prepared by the staff (NUREG-XXXX) or agency contractors (NUREG/CR-XXXX), (2) proceedings of conferences (NUREG/CP-XXXX), (3) reports resulting from international agreements (NUREG/IA-XXXX), (4) brochures

(NUREG/BR-XXXX), and (5) compilations of legal decisions and orders of the Commission and Atomic and Safety Licensing Boards and of Directors' decisions under Section 2.206 of NRC's regulations (NUREG-0750).

DISCLAIMER: This report was prepared as an account of work sponsored by an agency of the U.S. Government. Neither the U.S. Government nor any agency thereof, nor any employee, makes any warranty, expressed or implied, or assumes any legal liability or responsibility for any third party's use, or the results of such use, of any information, apparatus, product, or process disclosed in this publication, or represents that its use by such third party would not infringe privately owned rights. 
United States Nuclear Regulatory Commission

$\overline{\text { Protecting People and the Environment }}$

\section{Generation of a Broad- Group HTGR Library for Use with SCALE}

Manuscript Completed: August 2011

Date Published: June 2012

Prepared by:

R.J. Ellis, D.J. Lee*, D. Wiarda, M.L. Williams, U. Mertyurek

Oak Ridge National Laboratory

Managed by UT-Battele, LLC

Oak Ridge, TN 37831-6170

${ }^{*}$ Formerly of Oak Ridge National Laboratory

Don Algama, NRC Project Manager

NRC Job Code N6841

Office of Nuclear Regulatory Research 



\begin{abstract}
With current and ongoing interest in high temperature gas reactors (HTGRs), the U.S. Nuclear Regulatory Commission (NRC) anticipates the need for nuclear data libraries appropriate for use in applications for modeling, assessing, and analyzing HTGR reactor physics and operating behavior. The objective of this work was to develop a broad-group library suitable for production analyses with SCALE for HTGR applications. Several interim libraries were generated from SCALE fine-group 238- and 999-group libraries, and the final broad-group library was created from Evaluated Nuclear Data File/B Version ENDF/B-VII Release 0 cross-section evaluations using new ORNL methodologies with AMPX, SCALE, and other codes. Furthermore, intermediate resonance (IR) methods were applied to the HTGR broadgroup library, and lambda factors and f-factors were incorporated into the library's nuclear data files. A new version of the SCALE BONAMI module named BONAMI-IR was developed to process the IR data in the new library and, thus, eliminate the need for the CENTRM/PMC modules for resonance selfshielding. This report documents the development of the HTGR broad-group nuclear data library and the results of test and benchmark calculations using the new library with SCALE. The 81-group library is shown to model HTGR cases with similar accuracy to the SCALE 238-group library but with significantly faster computational times due to the reduced number of energy groups and the use of BONAMI-IR instead of BONAMI/CENTRM/PMC for resonance self-shielding calculations.
\end{abstract}





\section{FOREWORD}

In recognizing the need for nuclear data appropriate for HTGR applications, a robust and versatile broadgroup nuclear data library for use with SCALE was generated for the U.S. Nuclear Regulatory Commission. An HTGR-appropriate 81-group energy structure was selected with energy boundaries that are a subset of the standard SCALE 238-group structure. This nuclear data library is intended for HTGR applications. The final broad-group library was generated directly from ENDF/B-VII files using the latest methodology, and the intermediate resonance parameters, lambda factors and f-factors for important nuclides were included in the new library. 



\section{CONTENTS}

$\underline{\text { Page }}$

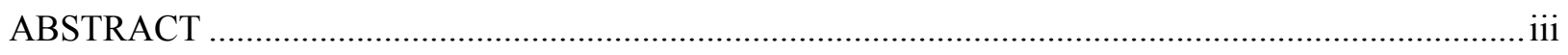

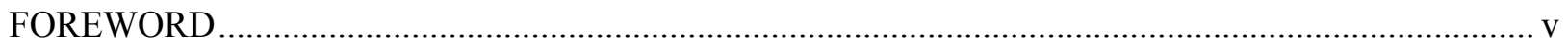

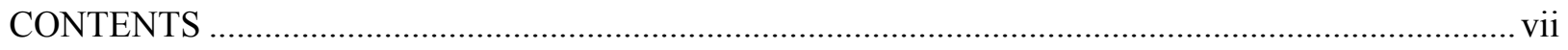

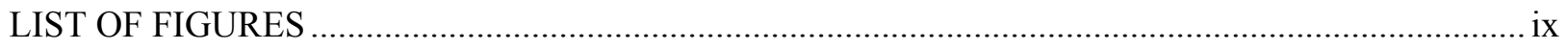

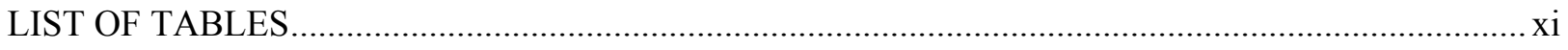

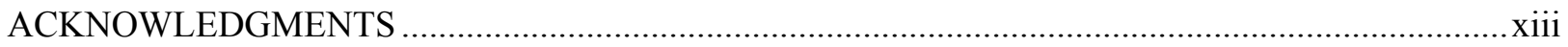

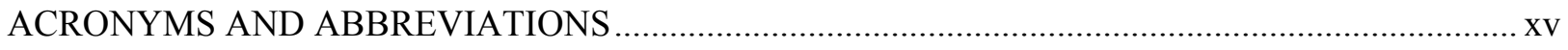

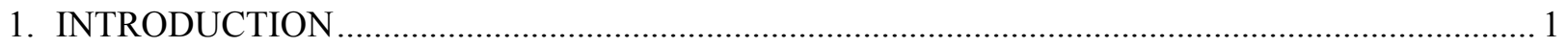

2. PROCEDURES AND METHODOLOGY FOR GENERATING HTGR LIBRARIES...................... 3

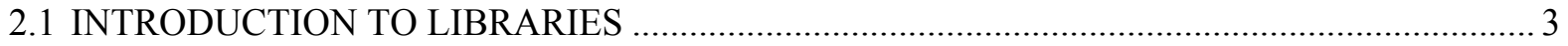

2.2 ISSUES RELATED TO HTGR NEUTRONICS AND NUCLEAR DATA ….............................. 3

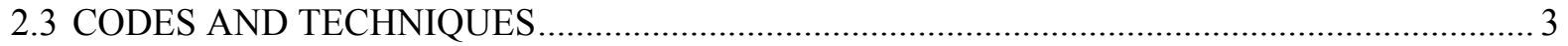

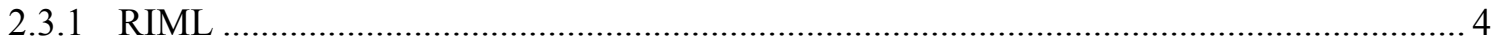

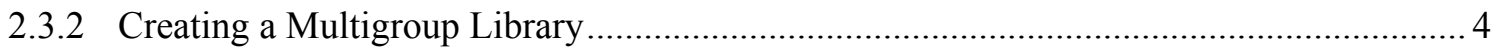

2.4 GENERATION OF LIBRARIES FROM ENDF/B-VII FILES ….............................................. 5

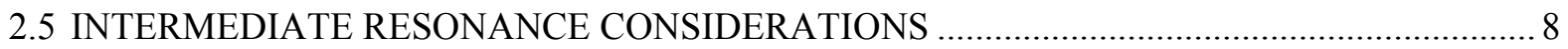

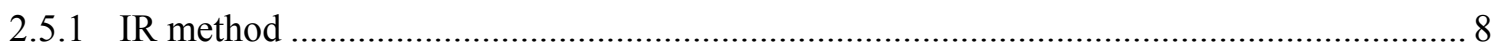

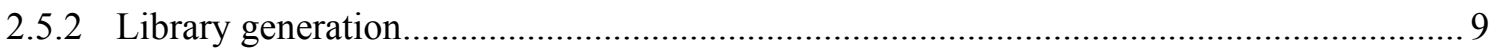

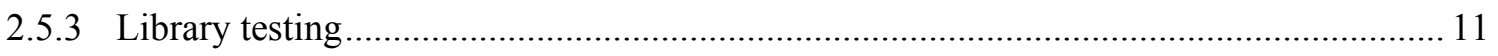

2.6 TESTING OF BONAMI-IR DURING IMPLEMENTATION INTO SCALE ............................ 11

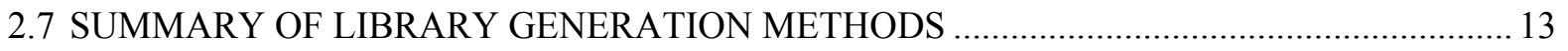

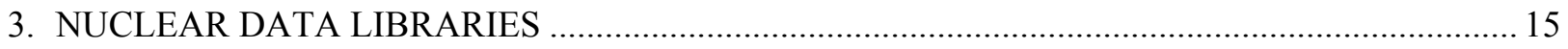

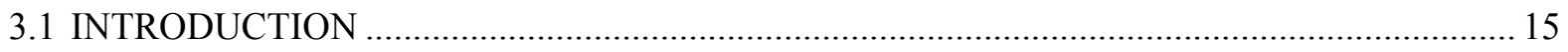

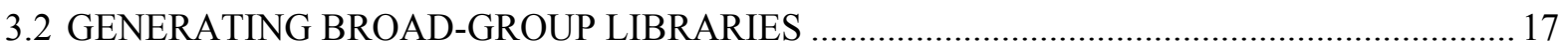

3.3 DESCRIPTION OF THE BROAD-GROUP LIBRARIES …................................................. 19

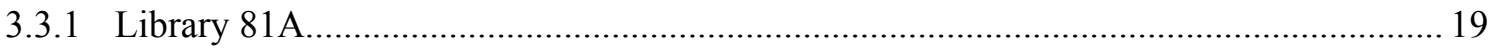

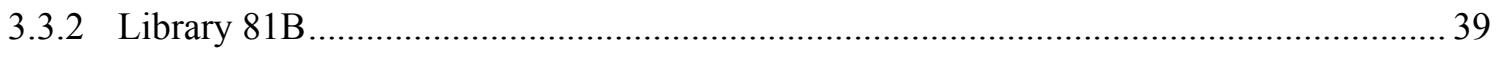

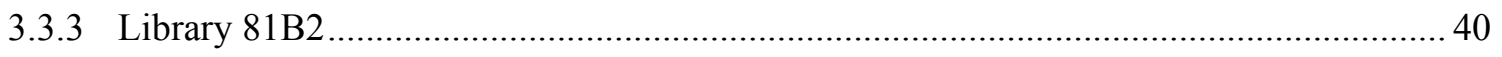

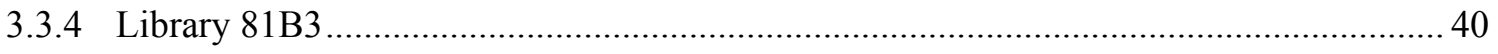

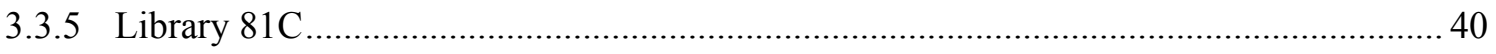

4. COMPARISON OF RESULTS WITH THE SCALE BROAD-GROUP LIBRARIES ..................... 41

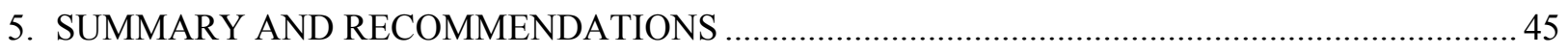

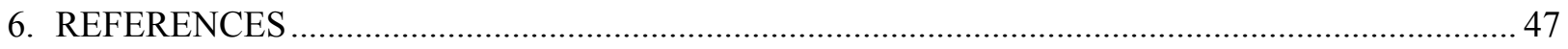


APPENDIX A DESCRIPTION OF INTERMEDIATE RESONANCE METHOD IN SCALE ...........A-1

A.1 Intermediate Resonance Approximation.................................................................................

A.2 Computation Of Hydrogen-Equivalent Lambda Factors .......................................................... A-4

APPENDIX B INPUT FILE FOR RADIAL CORE MODEL 999-GROUP (VHTR) MODEL............. B-1

APPENDIX C INPUT FOR GENERATING CENTRM POINTWISE FLUX WEIGHTING FUNCTIONS

APPENDIX D INPUT FOR TEST2R3_MG: SAMPLE JAPANESE HTTR BENCHMARK CASE ..D-1 APPENDIX E SCHEMATIC DIAGRAMS OF THE HTTR BENCHMARK CASE .......................... E-1

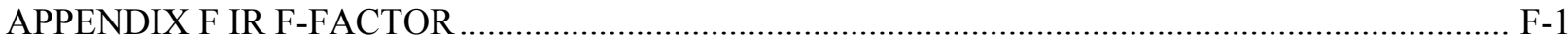




\section{LIST OF FIGURES}

$\underline{\text { Page }}$



Figure 2.2. AMPX sequence for producing neutron multigroup data................................................... 6

Figure 2.3. Comparison of CENTRM pointwise flux weighting functions for the HTGR temperatures. ... 8

Figure 3.1. Comparison of HTGR spectra in 999-group calculations for a range of temperatures. .......... 15

Figure 3.2. Comparison of HTGR spectra in 238- and 999-group calculations. .................................... 16

Figure 3.3. Comparison of HTGR spectra (238 group and 999 group) in the 1 to $10 \mathrm{eV}$ region............. 17

Figure 3.4. HTGR spectra in the 10 to $100 \mathrm{eV}$ region: comparison of fine-group solutions..................... 18

Figure 3.5. HTGR spectra in the 10 to $100 \mathrm{eV}$ range for broad and fine group libraries. ....................... 18

Figure 3.6. HTGR 238-group spectrum in the 10 to $100 \mathrm{eV}$ region: broad-group comparisons.............. 19 



\section{LIST OF TABLES}

$\underline{\text { Page }}$

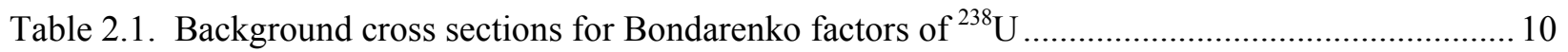

Table 2.2. Assessing the IR-methods improvement to the library: HTR pin-cell test problem ................. 11

Table 2.3. Infinite homogeneous medium of $1.26 \%$ enriched LEU and $\mathrm{H}$; background $\mathrm{XS} \sim 100 \mathrm{~b}$ and temperature $300 \mathrm{~K}$

Table 2.4. Infinite homogeneous medium of $1.26 \%$ enriched LEU and $\mathrm{H}$; background $\mathrm{XS} \sim 50 \mathrm{~b}$ and temperature $300 \mathrm{~K}$

Table 2.5. Infinite homogeneous medium of $1.26 \%$ enriched LEU and $\mathrm{H}$; background $\mathrm{XS} \sim 25 \mathrm{~b}$

Table 2.6. Simplified PWR pin cell $3.34 \%$ enriched $\mathrm{UO}_{2}$, pitch $=1.44 \mathrm{~cm}$; pellet $\mathrm{OR}=1.44 \mathrm{~cm}$; temperature $300 \mathrm{~K}$

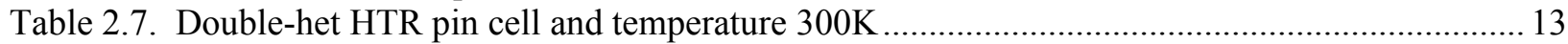

Table 3.1. Neutron energy group structure comparisons for 999-, 238-, and 81-group.......................... 20

Table 4.1. $\mathrm{k}_{\text {eff }}$ comparisons for MG KENO homogeneous cell HTGR model ....................................... 41

Table 4.2. $\mathrm{k}_{\mathrm{eff}}$ comparisons for homogeneous 1-D radial model ....................................................... 41

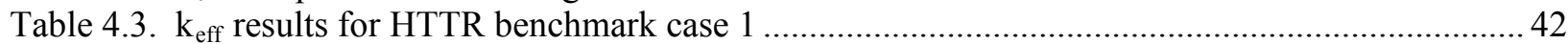

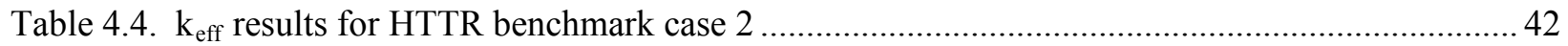

Table 4.5. $\mathrm{k}_{\text {eff }}$ results for HTR-10 pebble unit cell (1200K fuel, 900K coolant) .................................... 43

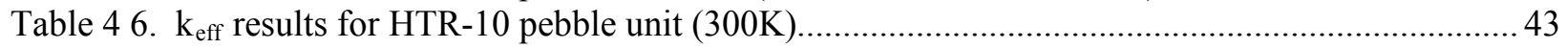

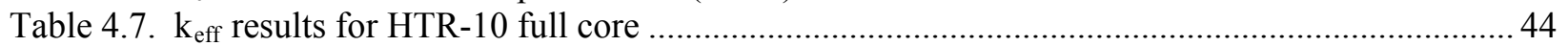





\section{ACKNOWLEDGMENTS}

This project was supported by the U.S. Nuclear Regulatory Commission, Office of Nuclear Regulatory Research. The authors are grateful for the assistance and support of Don Algama of the NRC Office of Nuclear Regulatory Research. The authors are grateful for the support and guidance of ORNL project managers Mike Dunn and Steve Bowman. The authors thank Harold Smith, Germina Ilas, and Matthew Jessee of ORNL and Don Carlson of NRC for their technical reviews. Also, thanks are extended to Angie Alford and Debbie Weaver for their efforts in preparing this manuscript for publication. 



\section{ACRONYMS AND ABBREVIATIONS}

$1-\mathrm{D}$

2-D

3-D

AMPX

ASME

CE

CENTRM

DCS

ENDF

ENDF/B-VII.0

HTGR

HTR

HTS

HTTR

HX

IR

LWR

MOC

$\mathrm{MWd} /$ te U

MWt

NGNP

NPP

NR

NRC

OE

ORNL

P\&IC

PBR

pcm

PSA

PW

PWR

RB

RG

SAS1X

SDC

SF

VHTR

WR

XML one dimensional

two dimensional

three dimensional

Analytical Methods Nuclear Cross-Section Processing Computer Code System

American Society of Mechanical Engineers

continuous energy

Continuous Energy Transport Module

data control system

evaluated nuclear data file

evaluated nuclear data file version VII

high temperature gas reactor

high temperature reactor

heat transport system

High Temperature Engineering Test Reactor

heat exchanger

intermediate resonance

light-water reactor

method of characteristics

megawatt-days per metric ton of uranium

megawatt thermal

next generation nuclear plant

nuclear power plant

narrow resonance

U.S. Nuclear Regulatory Commission

operating experience

Oak Ridge National Laboratory

pressure and inventory control

pebble bed reactor

parts per hundred thousand (cent mille)

probabilistic safety assessment

pointwise

pressurized water reactor

reactor building

regulatory guide



shutdown cooling

spent fuel

very high temperature reactor

wide resonance

extensible markup language 



\section{INTRODUCTION}

Analyses and simulations for high temperature gas reactor (HTGR) models require appropriate nuclear data libraries. In order to perform timely production calculations, a suitable broad-group neutron energy structure is required. Calculations using the broad-group library need to provide results comparable to calculations performed with fine-group libraries or continuous energy calculations.

Until now, most broad-group libraries have been prepared or generated with the intention of being suitable for light water reactors (LWRs). In this work, it is the goal to generate a broad-group nuclear data library for use in the Oak Ridge National Laboratory (ORNL) SCALE code system $[1,2]$ for HTGR applications. Several broad-group HTGR cross-section libraries were produced with SCALE modules (e.g. MALOCS) or through the use of AMPX $[3,4]$ modules. The selection of a suitable broad-group neutron energy structure resulted from analysis and assessment of HTGR neutron spectra and features of neutron resonances and reactions. The final HTGR 81-group library produced in this work was generated directly from ENDF/B-VII nuclear data files using ORNL library generation techniques and procedures. In addition, intermediate resonance (IR) treatment methods were applied to generate intermediate resonance (IR) parameters (including lambda factors and f-factors) that were added to the library. Furthermore, some additions and augmentations were made to the SCALE code software (in particular, BONAMI-IR) to implement the capability to utilize the IR parameters. The 81-group library is expected to be released in SCALE 6.2.

This report provides details of the process in which the broad-group structure of neutron energy group boundaries was determined. In addition, testing of model scenarios and benchmark calculations were completed using SCALE for a range of representative HTGR-related models. The results from SCALE calculations using the new HTGR broad-group libraries were compared with similar calculations using fine-group and ultra fine-group libraries and also with continuous energy KENO and MCNP [5] model results. 



\section{PROCEDURES AND METHODOLOGY FOR GENERATING HTGR LIBRARIES}

The methodology for producing a broad-group nuclear data library for HTGR applications in SCALE modeling and simulation utilized AMPX and SCALE software modules in conjunction with analysis and interpretation of calculated relevant neutron spectra.

\subsection{INTRODUCTION TO LIBRARIES}

For this work, the main goal was to create an efficient and effective broad-group nuclear data library that would be suitable for use with SCALE HTGR models for production cases ranging from room temperature to $2000 \mathrm{~K}$. The standard SCALE ENDF/B-VII cross-section library for reactor analysis contains 238 neutron energy groups. Recently, a fine-group library was generated, using a HTGR weighting function, with nuclear data in 999 neutron energy groups. An HTGR broad-group library with 81 energy groups was produced from this 999-group library. The libraries discussed in this report are all based on ENDF/B-VII nuclear data files.

\subsection{ISSUES RELATED TO HTGR NEUTRONICS AND NUCLEAR DATA}

HTGRs operate under conditions quite different from LWRs and pressurized heavy water reactors (PHWRs) for which many nuclear data libraries have been generated. The nuclear data libraries for HTGRs generally need to be suitable for the higher temperatures and characteristic neutron flux spectra that are generated in these reactors. There are special neutron resonances and material concerns associated with HTGR neutronics. Usually, fine group structure is needed in the nuclear data libraries so that all the neutron absorption, capture, and fission processes are appropriately simulated.

In order to generate a broad-group nuclear data library suitable for HTGR models, careful establishment of neutron energy boundaries is required such that major resonances and reactions will be treated properly. Various broad-group neutron energy structures were considered and assessed in this work, with reference to earlier broad multigroup libraries. The results of SCALE model scenarios with broad-group nuclear data libraries were compared against cases utilizing fine-group SCALE nuclear data libraries (238 and 999 groups). These cases were also compared against MCNP and KENO continuous energy simulations to assess the appropriateness of the broad-group libraries.

\subsection{CODES AND TECHNIQUES}

SCALE was used in this work in conjunction with AMPX $[3,4]$ and other nuclear data codes, such as RIML [8]. Monte Carlo calculations with MCNP and SCALE/KENO were used in addition to deterministic neutron transport simulations. Representative HTGR pin cell and full core models were analyzed. Furthermore, a series of HTGR benchmark model scenarios were assessed with the different nuclear data libraries to test the suitability of the newly generated broad-group nuclear data libraries. In addition to using ENDF/B-VII data files with appropriate weighting functions to generate broad-group nuclear data for use with HTGRs, appropriate nuclide-dependent Bondarenko IR f-factors and lambda factors were implemented with the nuclear data. Necessary modifications to implement the IR methodology in SCALE were performed and used in the analyses. 


\subsubsection{RIML}

RIML [8] is a code for generating IR parameters, self-shielded cross sections, subgroup levels and weights, and the associated AMPX master libraries. RIML is a control module composed of three separate programs: RILAMB, IRVING, and SUBGR. RILAMB generates IR parameters for the homogeneous mixtures and self-shielded cross sections as a function of background cross section for the homogeneous and heterogeneous geometries. Self-shielded cross sections are converted into the Bondarenko factors and into the resonance integral table. IR parameters and Bondarenko factors are to be included or replaced in the master AMPX library using IRVING. SUBGR uses the resonance integral table created by RILAMB to generate the subgroup levels and weights. These subgroup data can be used in a transport lattice code, such as DeCART, which uses the subgroup method to self-shield resonance group cross sections.

The wide and the narrow resonance (NR) approximations have been combined [10], together forming an IR approximation that is good for the resonance range from a few electron volts up to $100 \mathrm{keV}$. IR parameters can be used to interpolate between the narrow and wide resonance approaches. Because nearly all deterministic transport codes use multigroup cross sections, utilizing between 30 and 300 groups, it is very important to use the appropriate approximations to estimate the effective group self-shielded cross section.

Many kinds of methods have been developed for the resonance treatment in this energy range. However, in many cases the basic approach for the resonance treatment is similar. The self-shielded cross sections are tabularized in advance as a function of some parameter such as background cross section by using various methods. One of the typical methods is to obtain the self-shielded cross sections by solving the continuous or ultrafine group slowing-down equation and to obtain the corresponding background cross section to complete the self-shielded cross-section table.

The CENTRM/PMC codes are used to estimate the self-shielded group cross sections by solving the slowing-down equation with the continuous energy cross sections and integrating the continuous energy flux and cross section over each group. These effective self-shielded group cross sections are used in SCALE multigroup/transport codes (e.g. NEWT, KENO) directly. The SCALE CENTRM/PMC codes can be used to obtain the self-shielded group cross-section table through a slight modification and a combination with a module to generate the corresponding background cross section.

The program RILAMB (ㄹesonance Integral and Lambda) has been developed to compute IR parameters and self-shielded cross-section tables using the results from CENTRM/PMC in the SCALE system. IR parameters are generated for a set of homogeneous mixtures, and self-shielded group cross-section tables are generated for the specified homogeneous and heterogeneous geometries. The program IRVING uses the self-shielded cross-section tables to generate Bondarenko factors and resonance integral tables. IRVING replaces the original NR Bondarenko factors in the master AMPX library and adds the IR parameters.

\subsubsection{Creating a Multigroup Library}

A flow diagram is presented in Figure 2.1 to illustrate the automated procedure to generate the AMPX master library from ENDF/B evaluations. 


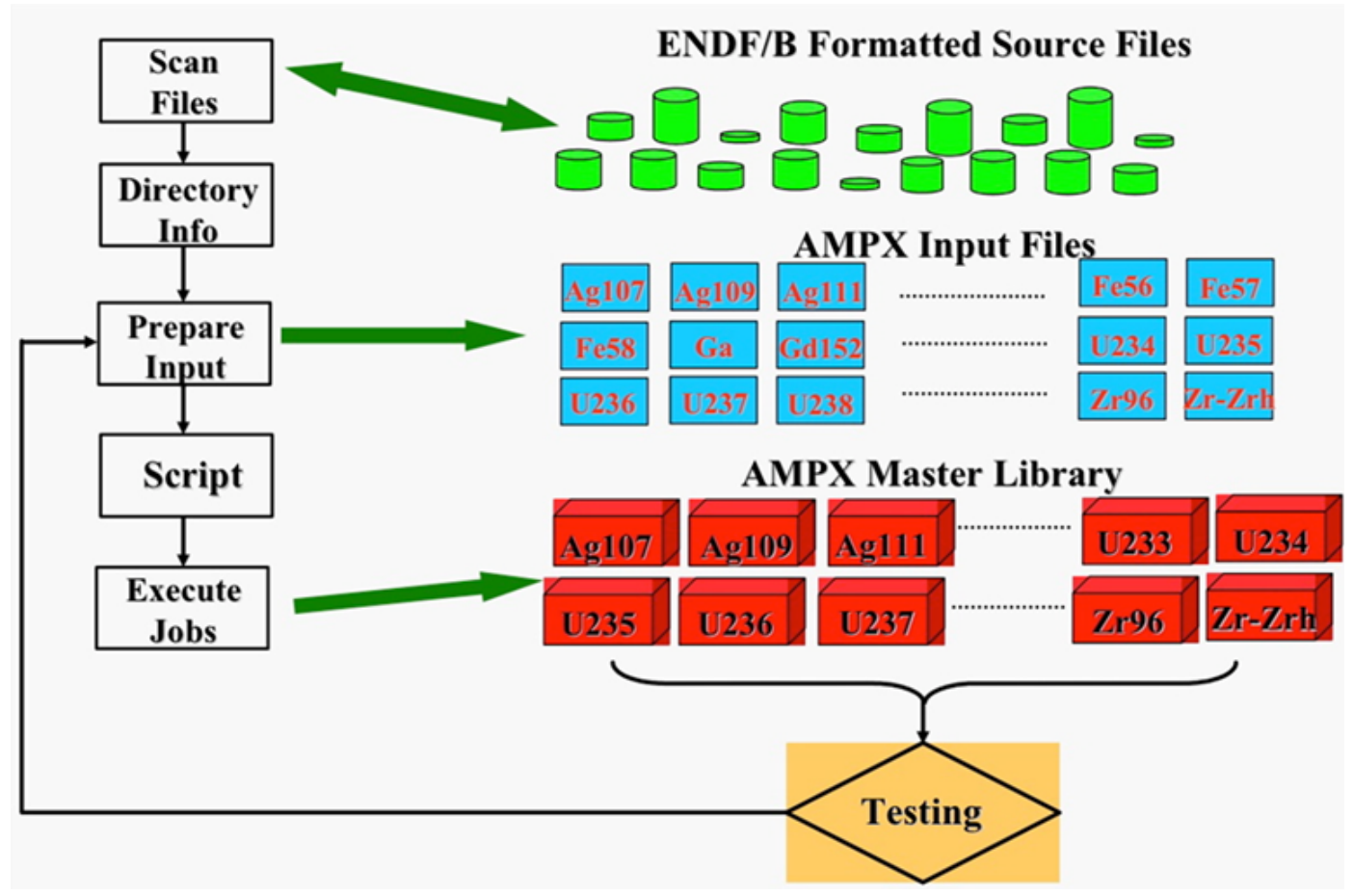

Figure 2.1. Work flow for AMPX master library creation.

\subsection{GENERATION OF LIBRARIES FROM ENDF/B-VII FILES}

In this ORNL process, the input files are generated automatically using extensible markup language (XML) templates. The general flow of creating the nuclear data in this methodology is depicted in Figure 2.2. The AMPX modules and utility codes employed in this process are described below and shown in the flowchart. 


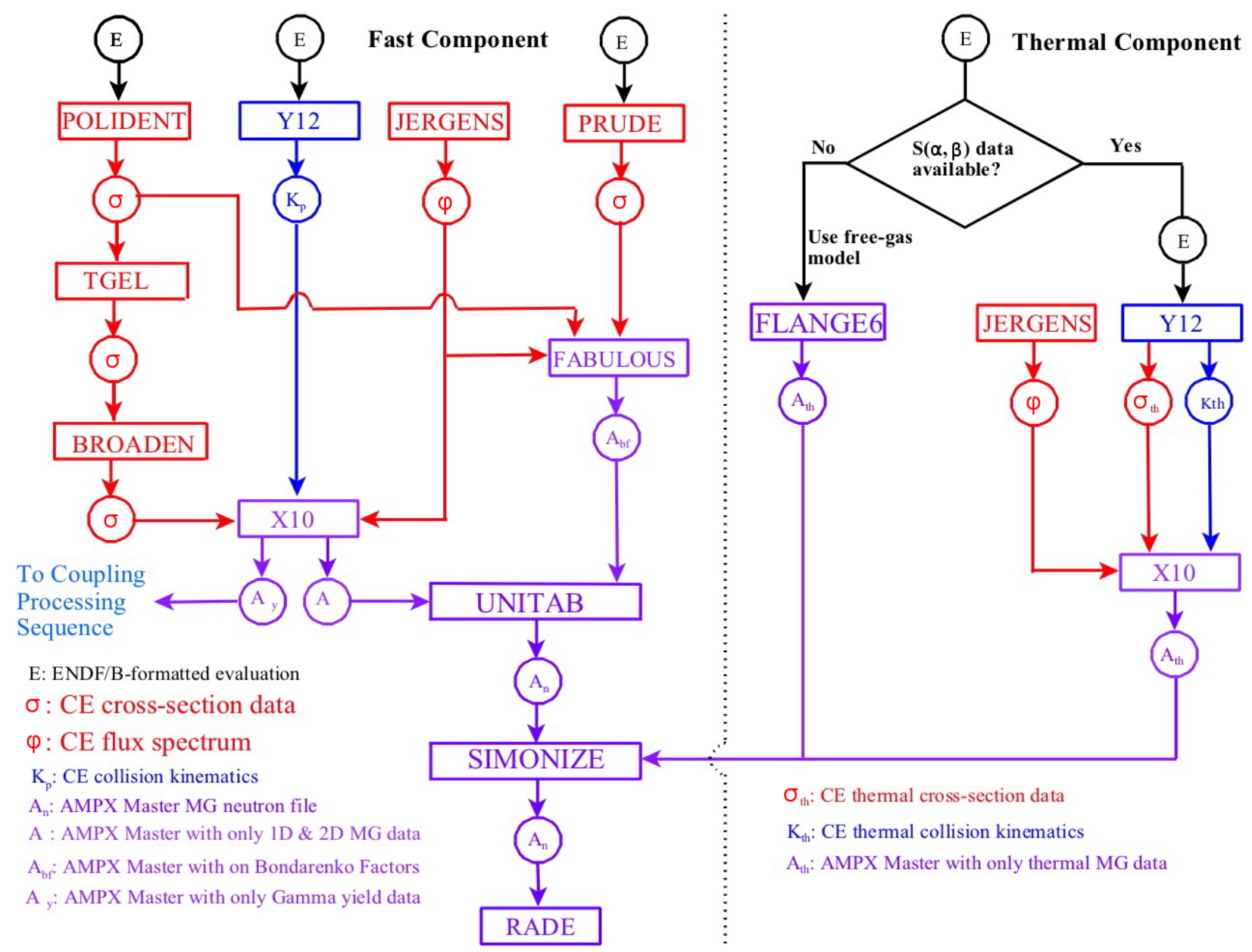

Figure 2.2. AMPX sequence for producing neutron multigroup data.

The following AMPX modules are used in the process to produce a neutron multigroup library.

POLIDENT: Creates pointwise cross-section data at $0 \mathrm{~K}$ from the ENDF/B-VII data files. For resonance nuclides, POLIDENT contains a procedure that determines a point energy mesh in the resolved resonance region and calculates the cross sections on that energy mesh. The pointwise data are stored as $\mathrm{x}-\mathrm{y}$ values on a linear-linear grid.

TGEL: When all of the cross-section data are produced on a linear-linear grid, the sum of a group of linear functions is itself linear; however, simply linearizing the data that are given in an evaluation does not lead to this consistency. To ensure consistency, the total cross section and other "redundant" reactions (e.g., fission, inelastic) are formed by summing the partial values. This module is used to ensure that all redundant reactions are equal to the sum of the partial reactions.

BROADEN: This module is used to Doppler broaden the cross-section data.

PRUDE: For nuclides with unresolved resonance data, this module is run to produce point averaged cross sections that are a function of temperature and background cross section (background cross sections are discussed in more detail in Section 2.5). The background cross section is simply defined as the cross section per unit atom of a nuclide of the mixture (other than the nuclide itself) in which the nuclide 
is mixed. In the sequences that were prepared, temperatures of 293,900 , and $2100 \mathrm{~K}$ were chosen, along with background values of $10^{-6}, 1,10,100,1000,10^{4}, 10^{5}, 10^{6}$, and $10^{8}$ barns.

FABULOUS: For all nuclides, the point data from PRUDE (if applicable) and POLIDENT are passed to this module with the weighting spectrum file. FABULOUS uses the same temperatures and background cross sections described for PRUDE to numerically Doppler broaden the functions exterior to the unresolved region, after which the functions are spliced together with the appropriate unresolved functions. These spliced functions are then used in a numerical scheme that calculates Bondarenko factors for all nuclides for elastic scattering, capture, fission, and total cross sections.

UNITAB and SIMONIZE: These modules are used to combine partial master libraries generated by FLANGE6, FABULOUS, and X10 into a cohesive AMPX MG master library for a given evaluation. The module combines the data into one AMPX MG master library after recalculating and renormalizing the data.

JERGENS: This module is used to generate the flux used to collapse point-wise data to MG format.

Y12: This module reads an ENDF/B evaluation and produces tabular double-differential collision kinematics data for all reactions. The functions it produces tell what particles are produced and at what energies and directions when a reaction is encountered at some source energy point. The output from Y12 is an AMPX tabular kinematics file.

X10: The weighting spectrum, the point data from BROADEN, and the kinematics data from Y12 are passed to X10. X10 produces a group-averaged AMPX master library.

FLANGE6: This module is used to produce thermal scattering matrices at 293, 600, 900, 1200, and $2100 \mathrm{~K}$ based on the free-gas scattering model.

RADE: This module is used to perform internal consistency checks on the AMPX master library.

To generate the 999-group library, we used the AMPX JERGENS module to generate a smooth weighting spectrum that has the form of a Maxwellian-1/E-fission spectrum-1/E above $10 \mathrm{MeV}$. For the 81-group library $81 \mathrm{~B} 3$ and $81 \mathrm{C}$, we used a custom flux as the weighting function. Figure 2.3 shows the pointwise flux generated in CENTRM (from the HTGR prismatic fuel SCALE input case listed in Appendix C) for two representative temperatures. The pointwise flux data (approximately 16,000 data points) at a temperature of $1800 \mathrm{~K}$ was chosen to be the weighting function for the generation from the ENDF/B-VII nuclear data files [11] of the 81-group library. 


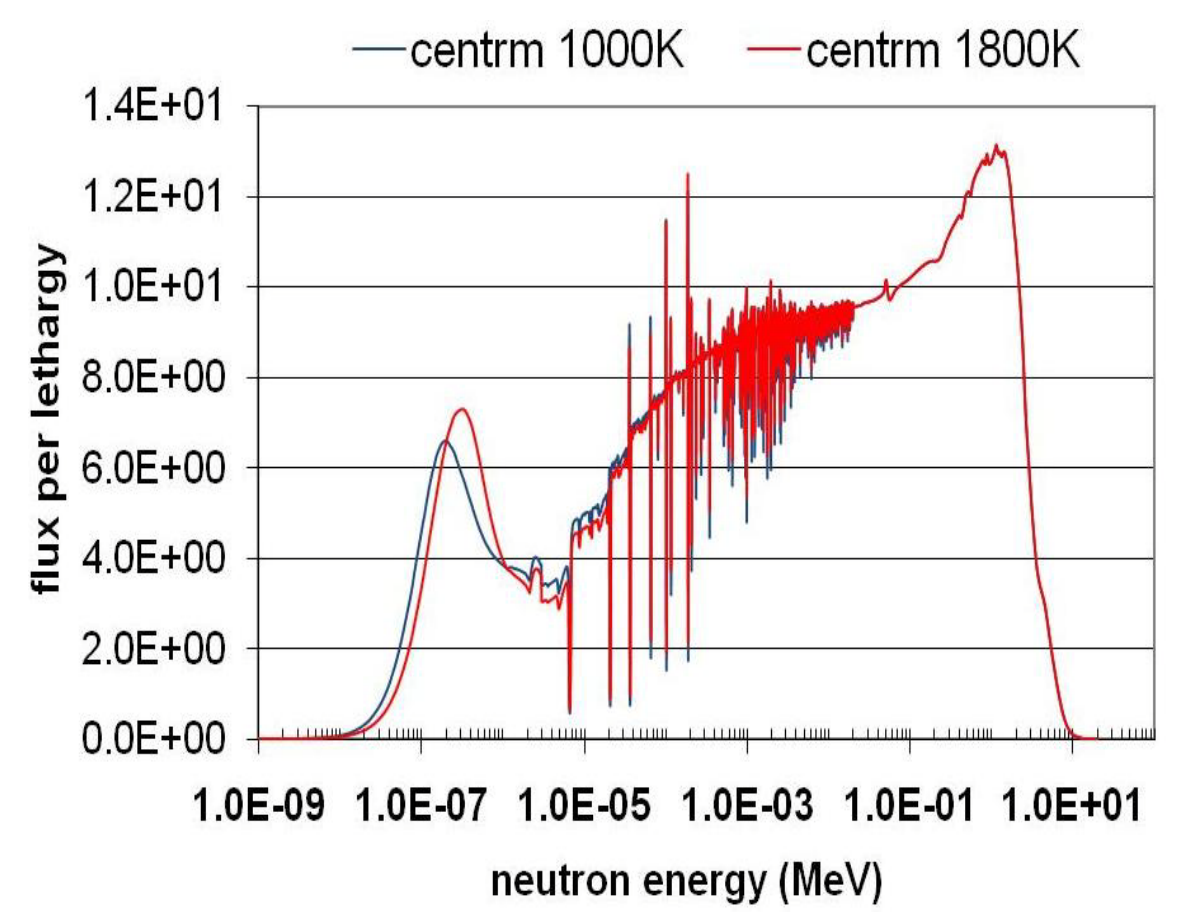

Figure 2.3. Comparison of CENTRM pointwise flux weighting functions for the HTGR temperatures.

\subsection{INTERMEDIATE RESONANCE CONSIDERATIONS}

This section is a summary of the new methods and data that were added as an IR treatment in the new library. The resonance data in SCALE 6.1 and all earlier versions of SCALE were based on the neutron spectrum from the narrow resonance approximation. With the new IR methods applied for selected isotopes (e.g., ${ }^{238} \mathrm{U}$ ), new Bondarenko factor tables were generated based on a more rigorous neutron flux spectrum. In addition, IR parameters (lambda factors) have been added for the evaluation of background cross sections in the resonance treatment with the IR approximation.

\subsubsection{IR method}

The effective shielded cross section in a resonance group $g$ can be written [10] as

$$
\sigma_{x, g}=\frac{\int_{\Delta u_{g}} \sigma_{x}(u) \phi(u) d u}{\int_{\Delta u_{g}} \phi(u) d u} .
$$

where $\varnothing=$ flux and $u=$ lethargy.

In the narrow resonance (NR) approach, the neutron spectrum is simply inversely proportional to the total cross section:

$$
\phi(u)=\frac{\text { constant }}{\Sigma_{\mathrm{t}}(u)} .
$$

In a more sophisticated IR method, the flux spectrum can be written as 


$$
\phi(u)=\frac{\sigma_{b}}{\sigma_{a}(u)+\sigma_{b}}
$$

where a background cross section is defined as

$$
\sigma_{b}=\frac{1}{N_{r}} \sum_{i=\text { all }} N_{i} \lambda_{i} \sigma_{p, i}
$$

$N_{r}$ is the atomic number density of the resonance nuclide, $N_{i}$ is the atomic number density of isotope $i$, $\lambda_{i}$ is the IR parameter of isotope $i$, and $\sigma_{p, i}$ is the potential cross section of isotope $i$. In case of heterogeneous problems, the background cross section can be adjusted as below using the equivalence theory:

$$
\sigma_{b} \rightarrow \sigma_{b}+\sigma_{e}
$$

where $\sigma_{e}$ is the escape cross section,

$$
\sigma_{e}=\frac{1}{N_{r}} \frac{a(1-c)}{\bar{l}}
$$

in which $a$ is the Bell factor, $c$ is the Dancoff factor, and $\bar{l}$ is the mean chord length of fuel region.

\subsubsection{Library generation}

As shown above, in order to apply the IR method, the resonance integrals of isotopes selected for IR treatment need to be recalculated either by using the IR definition of flux spectrum or using a neutron slowing-down solver such as CENTRM. The lambda factors also need to be generated for implementation in a new library to allow for the application of the IR method in the BONAMI-IR module in SCALE.

\section{New Bondarenko factors}

The Bondarenko factors of given resonance materials are computed using a pointwise (PW) flux spectrum for an infinite homogeneous mixture of the resonance nuclide combined with hydrogen. The hydrogen concentration in the mixture is varied to obtain the desired $\sigma_{b}$ values corresponding to different degrees of self-shielding for the particular resonance material. The temperature of the resonance material is also varied to account for the impact of Doppler broadening on self-shielding. CENTRM was used to calculate the PW flux in the homogeneous media for each hydrogen concentration (i.e., $\sigma_{b}$ ) and resonance Doppler temperature, for each resonance nuclide of interest. PMC was used to compute the corresponding selfshielded cross sections. The Bondarenko factor is the ratio of the self-shielded cross section from PMC divided by the infinitely dilute (unshielded) cross section in the library. For example in the case of ${ }^{238} \mathrm{U}$, CENTRM/PMC was run for three Doppler temperatures of 293, 900, and $2000 \mathrm{~K}$ and 93 different hydrogen concentrations. This corresponds to 3 X $93=279$ CENTRM/PMC cases. The Bondarenko factors at the desired background cross section values $\left(\sigma_{b}\right)$ in the library were interpolated from these results. Table 2.1 shows the final background cross section values for which ${ }^{238} \mathrm{U}$ Bondarenko factors are tabulated in the library. The Bondarenko factors for other resonance materials were generated similarly, but different hydrogen concentrations may have been used. 
Table 2.1. Background cross sections for Bondarenko factors of ${ }^{238} U$

\begin{tabular}{c|c||c}
\hline $\begin{array}{c}\text { Background cross section } \\
\text { (barns) }\end{array}$ & $\begin{array}{c}\text { Background cross section } \\
\text { (barns) }\end{array}$ & $\begin{array}{c}\text { Background cross section } \\
\text { (barns) }\end{array}$ \\
\hline $1.00 \mathrm{E}-06$ & $1.20 \mathrm{E}+02$ & $1.00 \mathrm{E}+05$ \\
$1.00 \mathrm{E}+00$ & $1.60 \mathrm{E}+02$ & $1.00 \mathrm{E}+08$ \\
$1.00 \mathrm{E}+01$ & $3.20 \mathrm{E}+02$ & \\
$1.50 \mathrm{E}+01$ & $6.40 \mathrm{E}+02$ \\
$2.00 \mathrm{E}+01$ & $1.00 \mathrm{E}+03$ & \\
$3.00 \mathrm{E}+01$ & $2.00 \mathrm{E}+03$ & \\
$4.00 \mathrm{E}+01$ & $5.00 \mathrm{E}+03$ & \\
$6.00 \mathrm{E}+01$ & $1.00 \mathrm{E}+04$ & \\
$8.00 \mathrm{E}+01$ & $2.00 \mathrm{E}+04$ & \\
\hline
\end{tabular}

From the CENTRM/PMC outputs of these cases, the effective cross sections of ${ }^{238} \mathrm{U}$ have been collected and converted to Bondarenko factor tables using the following definition:

$$
f_{x, g}\left(T_{f}, \sigma_{b}\right)=\frac{\sigma_{x, g, e f f}\left(T_{f}, \sigma_{b}\right)}{\sigma_{x, g, \infty}},
$$

where $f$ is the Bondarenko factor, $T_{f}$ is the fuel temperature, $\sigma_{x, g, e f f}$ is the effective cross section of type $\mathrm{x}$, and $\sigma_{x, g, \infty}$ is the infinitely dilute cross section. These factors have been tabulated in the library at three temperatures $(293,900$, and $2000 \mathrm{~K})$ and 19 background cross sections $\left(1 \times 10^{-6}, 10,15,20,30,40,60\right.$, $80,120,160,320,640,1000,2000,5000,10,000,20,000,1 \times 10^{6}$, and $1 \times 10^{8}$ barns). Before this modification to the process, the original library had Bondarenko factors for only nine background cross sections.

\section{Lambda factors}

Lambda factors are also called hydrogen equivalence parameters and are calculated in the following procedure:

1) Compute a $\sigma_{a, g}^{238}$ table as a function of $\sigma_{b, g}^{238}$ by changing the particle number density of hydrogen for a homogeneous mixture at the fixed ${ }^{238} U\left(N^{238}\right)$ particle number density. The calculation of the effective cross sections has been done in CENTRM/PMC and RIML has been used for the processing of the data.

2) Compute the slowing-down calculation for a mixture of ${ }^{238} U\left(N^{238}\right),{ }^{1} H\left(N^{l}\right)$ and a target nuclide $x$ $\left(N^{x}\right)$, and obtain a new $\sigma_{a, g}^{238}($ CENTRM/PMC).

3) Read the corresponding $\sigma_{b, g}^{238}$ from the prepared $\sigma_{a, g}^{238}$ table (RIML).

4) Calculate the hydrogen equivalence parameter of the isotope $x$ using the following equation (RIML), where $\boldsymbol{\sigma}_{\boldsymbol{p}}$ is the potential cross section (refer to Appendix A).

$$
\lambda_{g}^{x}=\frac{\sigma_{b, g}^{238} N^{238}-N^{238} \lambda_{g}^{238} \sigma_{p}^{238}-N^{1} \lambda_{g}^{1} \sigma_{p}^{1}}{N^{x} \sigma_{p}^{x}} .
$$


The above procedure has been applied to all the isotopes in the old library, and the calculated lambda factors have been added to a new library at MT=2000. The lambda factors have been generated for a single fuel temperature of $300 \mathrm{~K}$.

\subsubsection{Library testing}

A simple HTGR pin cell has been used for testing the implemented method. In the model, the fuel kernels in the compact have been homogenized with graphite. The calculated k-effective values are summarized in Table 2.2 as a function of pin pitches. The fuel temperature used for testing is $900 \mathrm{~K}$ to match the cross-section data for the continuous energy calculations with KENO. NR and IR results from XSDRN are compared with continuous energy KENO (CE KENO), which is considered the reference solution in lieu of measured data, and with CENTRM, which is the reference method for generating the IR factors. In other words, BONAMI-IR results cannot be expected to be better than the CENTRM results. Note that the large differences between NR and CENTRM/CE KENO are expected. They demonstrate the inadequacy of the NR methodology for thermal systems, which is the reason for developing the IR method.

The results presented in Table 2.2 and the following tables in this section are based on preliminary investigations in the development of the IR methodology. The calculated results for the final method in Section 4 provide validation of the 81-group library for real world HTGR applications.

Table 2.2. Assessing the IR-methods improvement to the library: HTR pin-cell test problem

\begin{tabular}{|c|c|c|c|c|c|c|c|c|c|}
\hline \multirow[b]{2}{*}{$\begin{array}{l}\text { Pitch } \\
\text { (cm) }\end{array}$} & \multirow[b]{2}{*}{ CE KENO } & \multicolumn{8}{|c|}{ 238-Group KENO } \\
\hline & & BONAMI-NR & $\begin{array}{c}\Delta \mathrm{k}(\mathbf{p c m}) \\
\text { vs. CE } \\
\text { KENO }\end{array}$ & BONAMI-IR & $\begin{array}{c}\Delta \mathrm{k} \\
(\mathbf{p c m}) \\
\text { vs. CE } \\
\text { KENO }\end{array}$ & $\begin{array}{c}\text { CENTRM } \\
(\mathrm{n} 2 \mathrm{~d}=\mathbf{0}, \mathrm{ibr}=\mathbf{3})\end{array}$ & $\begin{array}{c}\Delta \mathbf{k}(\mathbf{p c m}) \\
\text { vs. CE } \\
\text { KENO }\end{array}$ & $\begin{array}{c}\text { NR vs. } \\
\text { CENTRM } \\
\Delta \text { k (pcm) }\end{array}$ & $\begin{array}{c}\text { IR vs. } \\
\text { CENTRM } \\
\Delta \mathrm{k} \text { (pcm) }\end{array}$ \\
\hline 1.5 & 0.97725 & 1.17518 & 19793 & 0.97398 & -327 & 0.97587 & -138 & 19931 & -189 \\
\hline 2.0 & 1.21413 & 1.39732 & 18319 & 1.20669 & -744 & 1.20919 & -494 & 18813 & -250 \\
\hline 2.5 & 1.38634 & 1.53469 & 14835 & 1.37588 & -1046 & 1.37967 & -667 & 15502 & -379 \\
\hline
\end{tabular}

For the 238-group library, the nuclear data library with IR treatment is significantly improved over the old library with the NR approach.

\subsection{TESTING OF BONAMI-IR DURING IMPLEMENTATION INTO SCALE}

As part of the process of implementing IR treatment into BONAMI (also called BONAMI-IR), several comparisons were made between BONAMI-IR, standard BONAMI (BONAMI-NR), CENTRM, and continuous energy KENO. The BONAMI-IR calculations used a new IR-relevant 238-group library (238ir) that was generated using the HTGR CENTRM weighting function. The results presented in Tables 2.3-2.5 were calculated with XSDRN for an infinite homogeneous medium of very low enriched uranium (LEU) and hydrogen with different background cross sections. Table 2.6 presents results for a simplified PWR pin cell, and Table 2.7 compares results for a doubly heterogeneous HTGR pin cell. The agreement between the BONAMI-IR and the CE KENO results is generally on the same order as the CENTRM results and significantly better than that of BONAMI-NR, with the exception of Table 2.6. The discrepancy between MG KENO/CENTRM and CE KENO for LWR pin cells has been previously observed with the standard SCALE V7-238 library and is under investigation. Note that the BONAMI-IR and CENTRM results are consistent. The fact that the BONAMI-NR result is better for this case is most likely due to a cancellation of errors. 
Table 2.3. Infinite homogeneous medium of $1.26 \%$ enriched LEU and $\mathrm{H}$; background $\mathrm{XS} \sim 100 \mathrm{~b}$ and temperature $300 \mathrm{~K}$

\begin{tabular}{|l|c|c|c|c|}
\hline Code & $\begin{array}{c}\text { BONAMI } \\
\text { method }\end{array}$ & $\begin{array}{c}\text { MG XS } \\
\text { library }\end{array}$ & Eigenvalue & $\begin{array}{c}\Delta \mathbf{k} \text { (pcm) } \\
\text { Diff from } \\
\text { CE KENO }\end{array}$ \\
\hline CE KENO & - & - & $1.09394 \pm 0.00021$ & - \\
\hline CENTRM & IR & $238 \mathrm{ir}$ & 1.09508 & 114 \\
\hline BONAMI & IR & $238 \mathrm{ir}$ & 1.09648 & 254 \\
\hline BONAMI & NR & 238 & 1.10282 & 888 \\
\hline
\end{tabular}

Table 2.4. Infinite homogeneous medium of $1.26 \%$ enriched LEU and $\mathrm{H}$; background $\mathrm{XS} \sim 50 \mathrm{~b}$ and temperature $300 \mathrm{~K}$

\begin{tabular}{|c|c|c|c|c|}
\hline Code & $\begin{array}{c}\text { BONAMI } \\
\text { method }\end{array}$ & $\begin{array}{c}\text { MG XS } \\
\text { library }\end{array}$ & Eigenvalue & $\begin{array}{c}\Delta \mathbf{k} \text { (pcm) } \\
\text { Diff from } \\
\text { CE KENO }\end{array}$ \\
\hline CE KENO & - & - & $1.05673 \pm 0.00019$ & - \\
\hline CENTRM & IR & $238 \mathrm{ir}$ & 1.05855 & 182 \\
\hline BONAMI & IR & $238 \mathrm{ir}$ & 1.05560 & -113 \\
\hline BONAMI & NR & 238 & 1.06525 & 852 \\
\hline
\end{tabular}

Table 2.5. Infinite homogeneous medium of $1.26 \%$ enriched LEU and H; background XS $\sim 25 \mathrm{~b}$

\begin{tabular}{|c|c|c|c|c|}
\hline Code & $\begin{array}{c}\text { BONAMI } \\
\text { method }\end{array}$ & $\begin{array}{c}\text { MG XS } \\
\text { library }\end{array}$ & Eigenvalue & $\begin{array}{c}\Delta \mathbf{k} \text { (pcm) } \\
\text { Diff from } \\
\text { CE KENO }\end{array}$ \\
\hline CE KENO & - & - & $0.95583 \pm 0.00020$ & - \\
\hline CENTRM & IR & $238 \mathrm{ir}$ & 0.95861 & 278 \\
\hline BONAMI & IR & $238 \mathrm{ir}$ & 0.95812 & 229 \\
\hline BONAMI & NR & 238 & 0.96553 & 970 \\
\hline
\end{tabular}

Table 2.6. Simplified PWR pin cell $3.34 \%$ enriched $\mathrm{UO}_{2}$, pitch $=1.44 \mathrm{~cm}$; pellet $\mathrm{OR}=1.44 \mathrm{~cm}$; Temperature 300K

\begin{tabular}{|l|c|c|c|c|}
\hline \multicolumn{1}{|c|}{ Code } & $\begin{array}{c}\text { BONAMI } \\
\text { method }\end{array}$ & $\begin{array}{c}\text { MG XS } \\
\text { library }\end{array}$ & Eigenvalue & $\begin{array}{c}\Delta \mathbf{k} \text { (pcm) } \\
\text { Diff from } \\
\text { CE KENO }\end{array}$ \\
\hline CE KENO & - & - & $1.35578 \pm 0.00022$ & - \\
\hline MG KENO/CENTRM & IR & $238 \mathrm{ir}$ & $1.34903 \pm 0.00018$ & -675 \\
\hline MG KENO/BONAMI-IR & IR & $238 \mathrm{ir}$ & $1.34714 \pm 0.00019$ & -864 \\
\hline BONAMI/ XSDRN & NR & 238 & 1.34948 & -630 \\
\hline
\end{tabular}


Table 2.7. Double-het HTR pin cell and temperature $300 \mathrm{~K}$

\begin{tabular}{|l|c|c|c|}
\hline \multicolumn{1}{|c|}{ Code } & $\begin{array}{c}\text { MG XS } \\
\text { library }\end{array}$ & Eigenvalue & $\begin{array}{c}\Delta \mathbf{k} \text { (pcm) } \\
\text { Diff from } \\
\text { CENTRM double-het }\end{array}$ \\
\hline XSDRN/CENTRM & $238 \mathrm{ir}$ & 1.29596 & - \\
\hline XSDRN/BONAMI-IR & $238 \mathrm{ir}$ & 1.29797 & 201 \\
\hline
\end{tabular}

\subsection{SUMMARY OF LIBRARY GENERATION METHODS}

Several methods of nuclear data library generation were employed in this work. The MALOCS utility module in SCALE was used to condense existing SCALE nuclear data libraries into appropriate broadgroup energy structures using HTGR case-calculated weighting functions (based on case neutron flux distributions). This procedure was used in the creation of the interim broad-group libraries $81 \mathrm{~A}, 81 \mathrm{~B}$, and 81B2. The other major methodology for creation of a nuclear data library is to generate it directly from ENDF/B data files, using continuous energy (pointwise) weighting functions, such as generated with CENTRM. This process was used to generate the recent 999-group library for SCALE (with independent weighting function) and was used in generating a new IR-relevant 238-group library using the HTGR CENTRM weighting function. The $81 \mathrm{~B} 3$ broad-group library was also generated in this manner, using the neutron energy group structure of $81 \mathrm{~B} 2$, but with the CENTRM generated weighting function rather than the neutron flux from 999- and 238-group SCALE HTGR model calculations.

To provide additional computational efficiency by removing the need to use CENTRM/PMC for unit cell calculations, the final broad-group libraries were enhanced and augmented with IR lambda factors and ffactors. These IR-enhanced nuclear data libraries were used in case calculations for HTGR models using a developmental version of SCALE in which the new IR features can be accessed and used in cases as discussed in the following section. 



\section{NUCLEAR DATA LIBRARIES}

\subsection{INTRODUCTION}

The SCALE 6.1 code system includes both pointwise (PW) and multigroup (MG) libraries processed from ENDF/B-VII nuclear data files using SCALE and the AMPX code system. The PW data are used for two distinct functions in SCALE. First, they are used for three-dimensional (3D) continuous-energy (CE) Monte Carlo calculations with KENO. Second, they are used in the one-dimensional (1-D) CENTRM CE discrete ordinates code to compute pointwise flux spectra for generating self-shielded MG cross sections. The PW nuclear data are stored on a very fine energy mesh so that the value at any energy can be linearly interpolated with an error of less than $0.1 \%$.

Figure 3.1 presents a comparison of neutron spectra calculated with SCALE for a representative HTGR homogeneous prismatic fuel model case input, "vhtr" (listed in Appendix B), using a 999-group ENDF/BVII library at three different representative temperatures of $300 \mathrm{~K}, 900 \mathrm{~K}$, and $1700 \mathrm{~K}$. In addition, the 999-group HTGR neutron spectrum at $1700 \mathrm{~K}$ is compared with a 238-group spectrum at the same temperature in Figure 3.2. The 238-group ENDF/B-VII library is the most current and generally recommended library in SCALE 6.1. The 999-group library has been developed and used internally at ORNL for various studies [6]. This 999-group library allows calculations to be performed with an ultra fine neutron energy mesh, allowing multigroup calculations that more closely resemble continuous energy representations. Note that the 238-group structure is a subset of the 999-group structure, i.e., the boundaries of the 238-group structure align with boundaries in the 999-group structure.

Figure 3.2 compares the 238-group and the 999-group neutron flux spectra calculated for the SCALE vhtr input model (listed in Appendix B) at a temperature of $1700 \mathrm{~K}$. As seen in the figure, the spectra are very similar for the main characteristics. However, the 999-group spectra, by virtue of its near-continuous energy fine group aspects shows more detail and structure in the resolved and unresolved resonance regions.

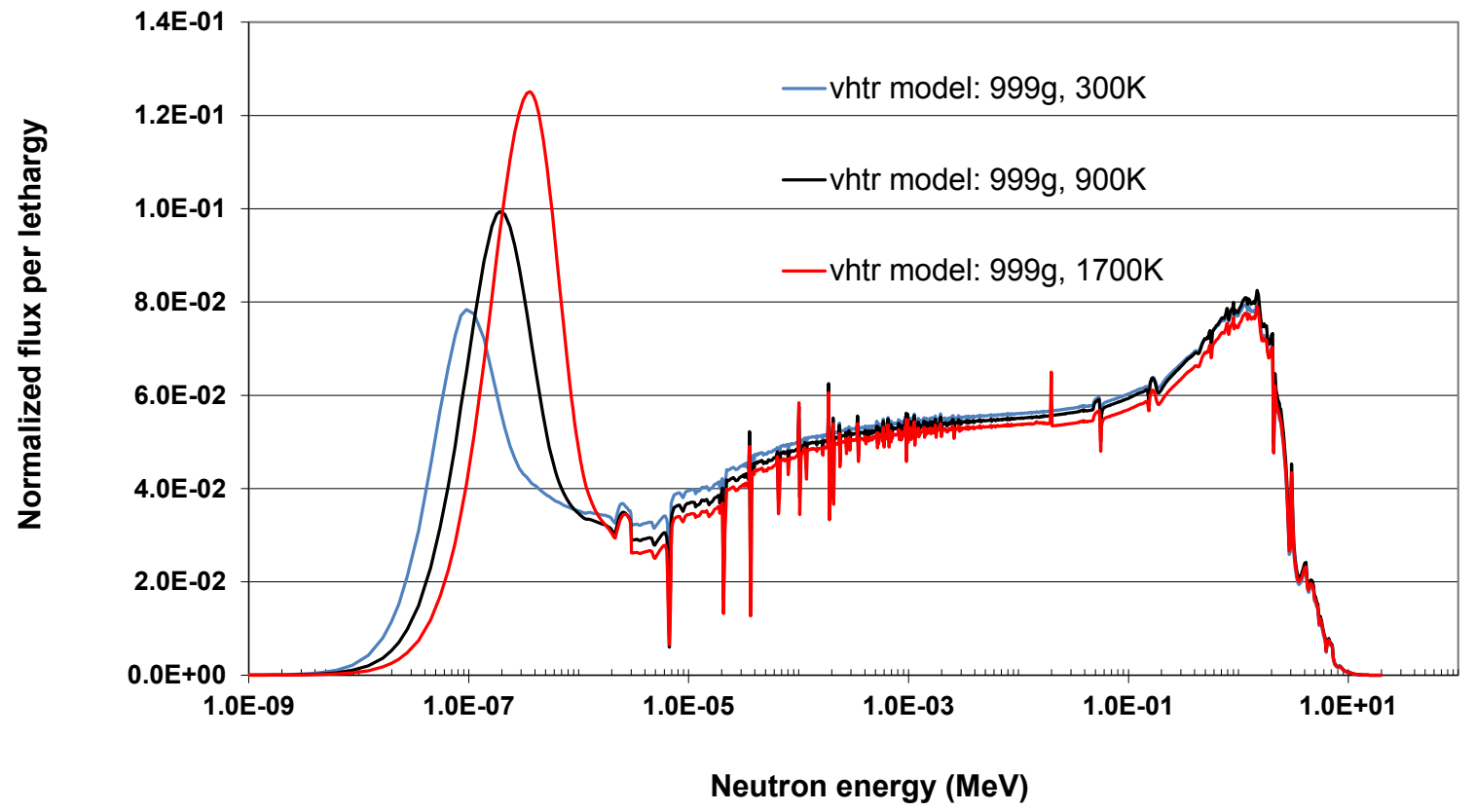

Figure 3.1. Comparison of HTGR spectra in 999-group calculations for a range of temperatures. 


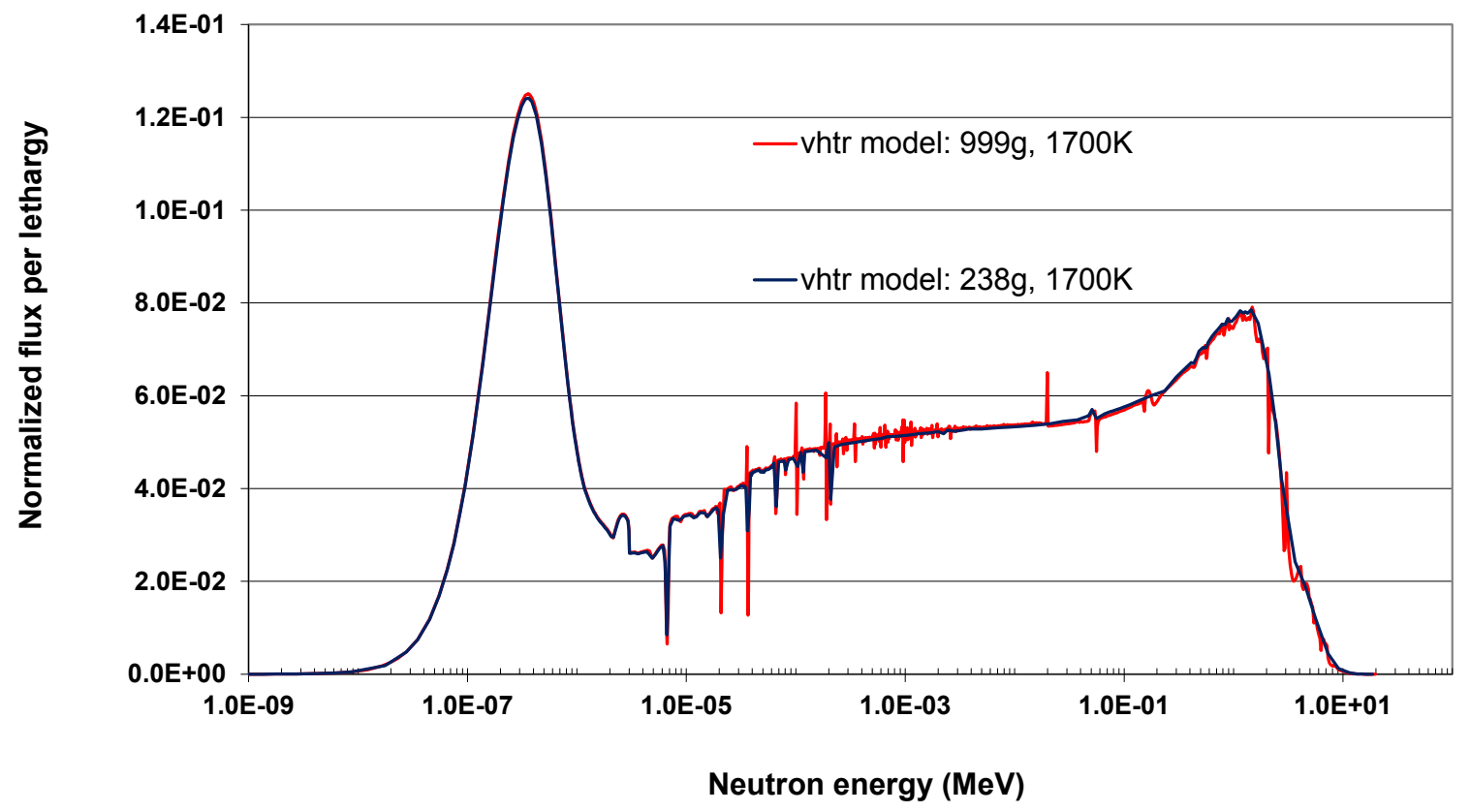

Figure 3.2. Comparison of HTGR spectra in 238- and 999-group calculations.

In this report, neutron flux spectra are plotted in two ways, with the y-axis for both methods representing the neutron flux level divided by the lethargy of the energy group bins (the natural log of the ratio of the bin upper energy to the bin lower energy). The first plotting method (used in Figure 3.1) plots the flux per unit lethargy against the average bin neutron energy. The other plotting method is to use histograms for the full neutron energy bin with each bin ranging from its lower to higher neutron energy limits.

Figure 3.3 provides more detail of the neutron spectra calculated with SCALE using 238- and 999-group nuclear data libraries in Figure 3.2 over the energy range of 1 to $10 \mathrm{eV}$, which includes the large neutron capture resonance at $6.7 \mathrm{eV}$ for ${ }^{238} \mathrm{U}$ reactions. The agreement in this large neutron capture resonance between the 238-group and the 999-group neutron flux representations with SCALE is quite good for HTGR simulation cases. Small differences are evident between the solutions due to the much finer neutron energy group structure in the 999-group nuclear data library. Note that the broad peak between 2 to $3 \mathrm{eV}$ in this and other figures is not physical. It is caused by truncation of the thermal scattering at $3 \mathrm{eV}$ in the SCALE multigroup (MG) libraries. This phenomenon is more noticeable for graphite. The impact on calculations is typically negligible, because there are no important resonances at this energy. The SCALE team has plans to address this problem in the near future. 


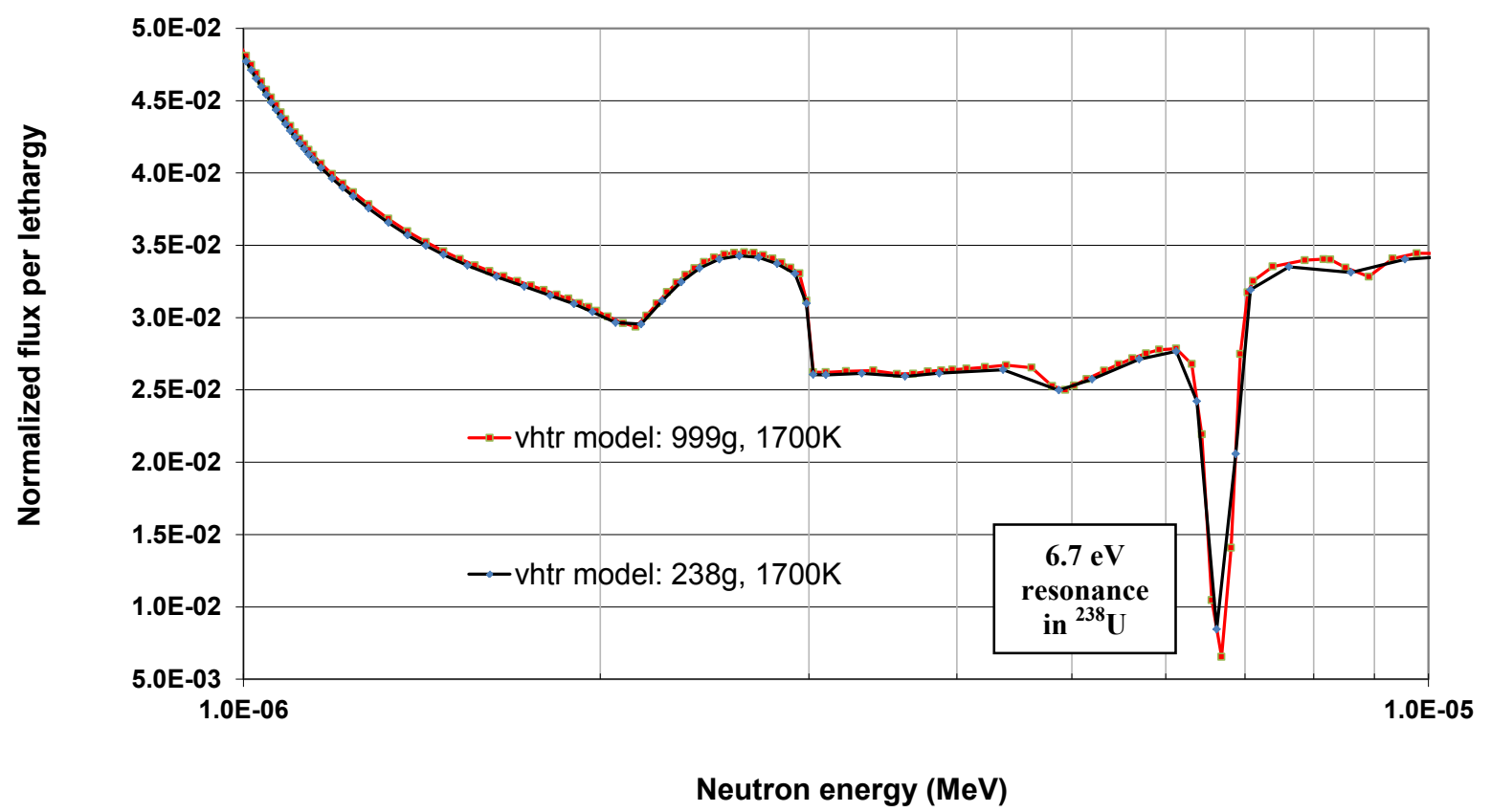

Figure 3.3. Comparison of HTGR spectra (238 group and 999 group) in the $1 \mathrm{to} 10 \mathrm{eV}$ region.

\subsection{GENERATING BROAD-GROUP LIBRARIES}

In this project, a number of interim broad-group nuclear data libraries were generated in 81 neutron energy groups; a previous study of the efficacy of nuclear data libraries for use in modeling VHTRs considered broad-group libraries with 72 and 79 groups [7]. Several broad-group neutron energy structures were devised by adding several judiciously placed energy bins to the library energy structure starting with that of the 72-group structure. The first 81-group broad-group library (81A) was a subset of the 999-group ultra fine group library with the neutron energy boundaries selected to capture the important resonances and features in the HTGR spectrum. The second broad-group structure (81B3) was established by shifting energy group boundaries in 81A that did not align with the 238-group structure so that the energy boundaries in $81 \mathrm{~B}$ are a subset of the standard SCALE fine-group 238-group library energy bin boundaries.

Figure 3.4 compares the fine detail in the 238- and 999-group flux solutions for the HTGR prismatic fuel case for the 10 to $100 \mathrm{eV}$ neutron energy range in the spectra. As can be seen, the 999-group flux solution shows deeper flux dips in the narrow resonances followed by increases in flux level at the lower energy side of the resonances, which is consistent with the somewhat reduced cross section that would be in effect. This is clearly evident for the $36 \mathrm{eV}\left(3.6 \times 10^{-5} \mathrm{MeV}\right)$ neutron resonance region seen in the middle of Fig. 3.4. 


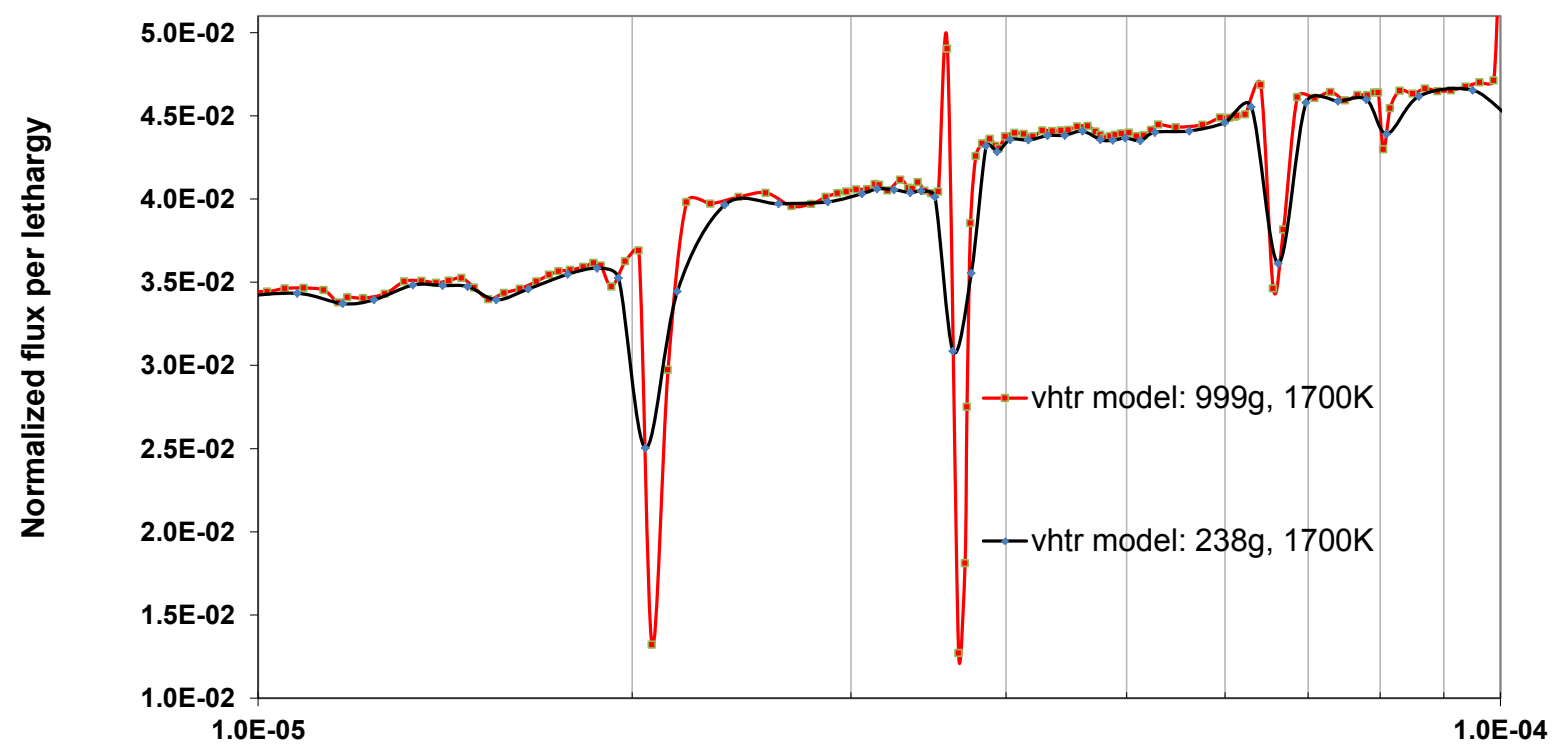

Neutron energy (MeV)

Figure 3.4. HTGR spectra in the 10 to $100 \mathrm{eV}$ region: comparison of fine-group solutions.

In Figure 3.5, histograms representing the 81 group neutron flux spectra solutions for the 81A and 81B3 nuclear data libraries in the 10 to $100 \mathrm{eV}$ neutron energy range are displayed in addition to the spectra from Fig. 3.4 to show the applicability of the chosen group energy structures to the resonances and details of the calculated multigroup neutron spectra.

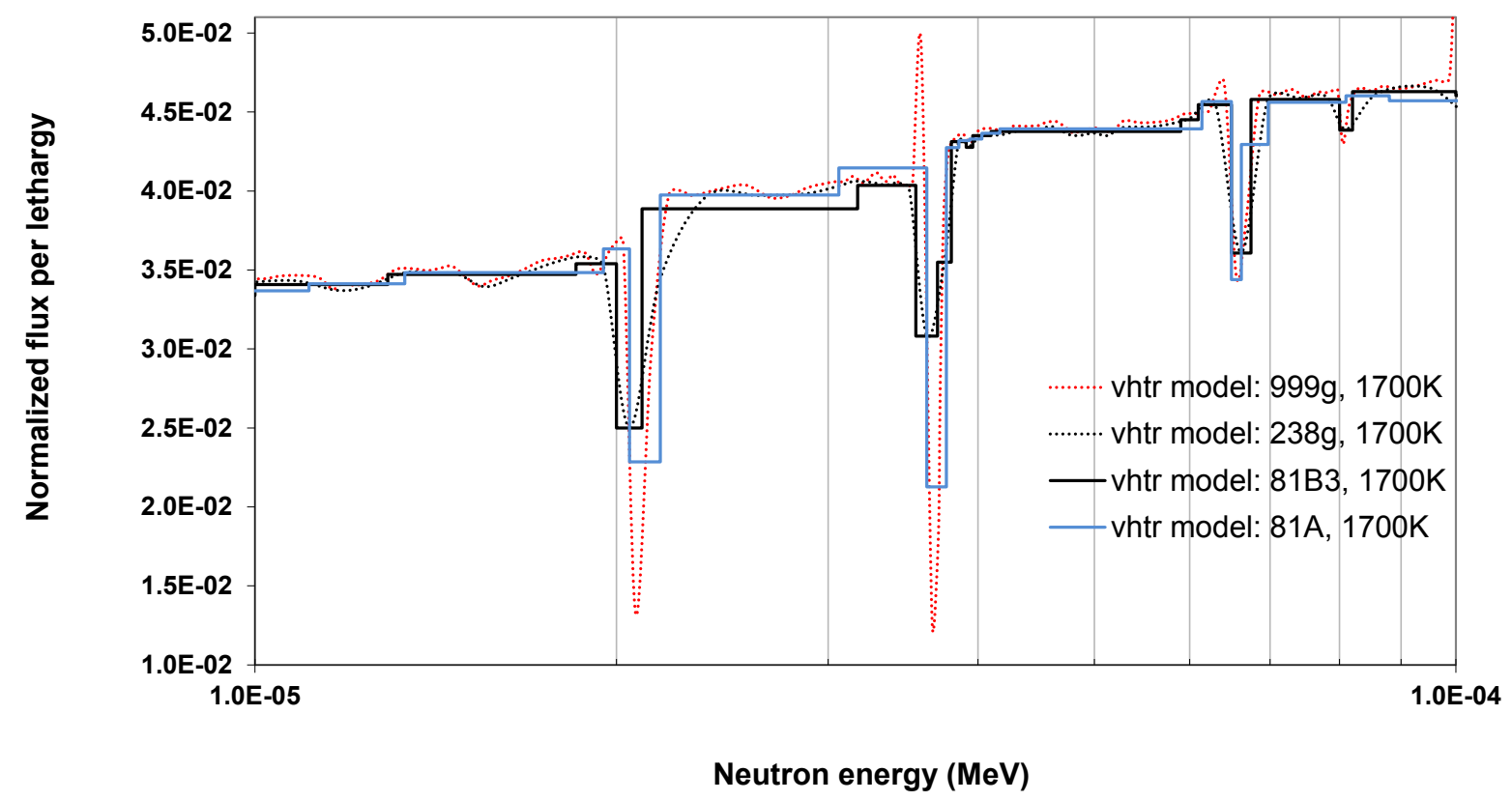

Figure 3.5. HTGR spectra in the 10 to $100 \mathrm{eV}$ range for broad and fine group libraries. 
Recall that the energy structure in library $81 \mathrm{~A}$ is a subset of the 999-group library energy structure, while the 81B3 energy structure is a subset of the 238-group SCALE fine-group library (which is also a subset of the 999-group library). As would be expected, the flux dips in the 81A spectrum agree more closely with the 999-group spectrum while the $81 \mathrm{~B} 3$ spectrum is similar to the 238-group spectrum. The comparison in Figure 3.5 is illustrated in a different way in Figure 3.6 by using a fine-group histogram for the 999-group solution in the 10 to $100 \mathrm{eV}$ range.



Figure 3.6. HTGR 238-group spectrum in the 10 to $100 \mathrm{eV}$ region: broad-group comparisons.

In Figure 3.6 the 999-group fine-group spectrum plotted in histogram format shows the details also seen in the curves in Figs. 3.4 and 3.5. Although differences can be seen between the 81A and 81B3 spectra, the energy boundaries for both 81-group libraries are adequately positioned to address the major HTGRrelated resonances for prismatic and pebble bed fuels.

\subsection{DESCRIPTION OF THE BROAD-GROUP LIBRARIES}

\subsubsection{Library 81A}

Library 81A was developed by condensing the new 999-group library with the SCALE module MALOCS using a 999-group neutron flux solution as a weighting function. The neutron-energy structure for 81A was selected from the available 999 neutron energy group boundaries, with care taken to select boundaries that surround major resonances and neutron spectrum features for HTGRs. Table 3.1 compares the energy group boundaries for the 999-group, the 238-group, and the various 81-group libraries. 
Table 3.1. Neutron energy group structure comparisons for 999-, 238-, and 81-group

\begin{tabular}{|c|c|c|c|c|}
\hline $\begin{array}{c}\text { Upper neutron } \\
\text { energy }(\mathrm{eV})\end{array}$ & $\begin{array}{l}\text { 999-group } \\
\text { structure }\end{array}$ & $\begin{array}{c}\text { SCALE } \\
\text { 238-group } \\
\text { structure }\end{array}$ & 81A groups & 81 B3,C groups \\
\hline $2.000 \mathrm{E}+07$ & 1 & \multirow{5}{*}{1} & \multirow[t]{28}{*}{1} & \multirow[t]{35}{*}{1} \\
\hline $1.964 \mathrm{E}+07$ & 2 & & & \\
\hline $1.900 \mathrm{E}+07$ & 3 & & & \\
\hline $1.845 \mathrm{E}+07$ & 4 & & & \\
\hline $1.790 \mathrm{E}+07$ & 5 & & & \\
\hline $1.733 \mathrm{E}+07$ & 6 & \multirow[t]{4}{*}{2} & & \\
\hline $1.691 \mathrm{E}+07$ & 7 & & & \\
\hline $1.649 \mathrm{E}+07$ & 8 & & & \\
\hline $1.608 \mathrm{E}+07$ & 9 & & & \\
\hline $1.568 \mathrm{E}+07$ & 10 & \multirow[t]{3}{*}{3} & & \\
\hline $1.530 \mathrm{E}+07$ & 11 & & & \\
\hline $1.492 \mathrm{E}+07$ & 12 & & & \\
\hline $1.455 \mathrm{E}+07$ & 13 & \multirow[t]{2}{*}{4} & & \\
\hline $1.419 \mathrm{E}+07$ & 14 & & & \\
\hline $1.384 \mathrm{E}+07$ & 15 & \multirow[t]{3}{*}{5} & & \\
\hline $1.350 \mathrm{E}+07$ & 16 & & & \\
\hline $1.317 \mathrm{E}+07$ & 17 & & & \\
\hline $1.284 \mathrm{E}+07$ & 18 & \multirow[t]{10}{*}{6} & & \\
\hline $1.252 \mathrm{E}+07$ & 19 & & & \\
\hline $1.221 \mathrm{E}+07$ & 20 & & & \\
\hline $1.191 \mathrm{E}+07$ & 21 & & & \\
\hline $1.162 \mathrm{E}+07$ & 22 & & & \\
\hline $1.133 \mathrm{E}+07$ & 23 & & & \\
\hline $1.105 \mathrm{E}+07$ & 24 & & & \\
\hline $1.078 \mathrm{E}+07$ & 25 & & & \\
\hline $1.051 \mathrm{E}+07$ & 26 & & & \\
\hline $1.025 \mathrm{E}+07$ & 27 & & & \\
\hline $1.000 \mathrm{E}+07$ & 28 & \multirow[t]{8}{*}{7} & & \\
\hline $9.753 \mathrm{E}+06$ & 29 & & \multirow[t]{8}{*}{2} & \\
\hline $9.512 \mathrm{E}+06$ & 30 & & & \\
\hline $9.278 \mathrm{E}+06$ & 31 & & & \\
\hline $9.048 \mathrm{E}+06$ & 32 & & & \\
\hline $8.825 \mathrm{E}+06$ & 33 & & & \\
\hline $8.607 \mathrm{E}+06$ & 34 & & & \\
\hline $8.395 \mathrm{E}+06$ & 35 & & & \\
\hline $8.187 \mathrm{E}+06$ & 36 & \multirow[t]{10}{*}{8} & & \multirow[t]{10}{*}{2} \\
\hline $7.985 \mathrm{E}+06$ & 37 & & \multirow[t]{10}{*}{3} & \\
\hline $7.788 \mathrm{E}+06$ & 38 & & & \\
\hline $7.596 \mathrm{E}+06$ & 39 & & & \\
\hline $7.408 \mathrm{E}+06$ & 40 & & & \\
\hline $7.225 \mathrm{E}+06$ & 41 & & & \\
\hline $7.047 \mathrm{E}+06$ & 42 & & & \\
\hline $6.873 \mathrm{E}+06$ & 43 & & & \\
\hline $6.703 \mathrm{E}+06$ & 44 & & & \\
\hline $6.592 \mathrm{E}+06$ & 45 & & & \\
\hline $6.434 \mathrm{E}+06$ & 46 & \multirow[t]{3}{*}{9} & & \multirow[t]{3}{*}{3} \\
\hline $6.376 \mathrm{E}+06$ & 47 & & \multirow[t]{2}{*}{4} & \\
\hline $6.219 \mathrm{E}+06$ & 48 & & & \\
\hline
\end{tabular}




\begin{tabular}{|c|c|c|c|c|}
\hline $\begin{array}{c}\text { Upper neutron } \\
\text { energy }(\mathrm{eV})\end{array}$ & $\begin{array}{c}\text { 999-group } \\
\text { structure }\end{array}$ & $\begin{array}{c}\text { SCALE } \\
\text { 238-group } \\
\text { structure }\end{array}$ & $81 \mathrm{~A}$ groups & 81B3,C groups \\
\hline $6.065 \mathrm{E}+06$ & 49 & \multirow{15}{*}{ sericture } & & \\
\hline $5.916 \mathrm{E}+06$ & 50 & & & \\
\hline $5.770 \mathrm{E}+06$ & 51 & & & \\
\hline $5.627 \mathrm{E}+06$ & 52 & & & \\
\hline $5.488 \mathrm{E}+06$ & 53 & & & \\
\hline $5.353 \mathrm{E}+06$ & 54 & & & \\
\hline $5.221 \mathrm{E}+06$ & 55 & & & \\
\hline $5.092 \mathrm{E}+06$ & 56 & & & \\
\hline $4.966 \mathrm{E}+06$ & 57 & & & \\
\hline $4.882 \mathrm{E}+06$ & 58 & & & \\
\hline $4.800 \mathrm{E}+06$ & 59 & & & 4 \\
\hline $4.724 \mathrm{E}+06$ & 60 & & & \\
\hline $4.607 \mathrm{E}+06$ & 61 & & & \\
\hline $4.493 \mathrm{E}+06$ & 62 & & & \\
\hline $4.398 \mathrm{E}+06$ & 63 & & & \\
\hline $4.304 \mathrm{E}+06$ & 64 & \multirow[t]{14}{*}{11} & & \\
\hline $4.183 \mathrm{E}+06$ & 65 & & \multirow[t]{14}{*}{5} & \\
\hline $4.066 \mathrm{E}+06$ & 66 & & & \\
\hline $3.965 \mathrm{E}+06$ & 67 & & & \\
\hline $3.867 \mathrm{E}+06$ & 68 & & & \\
\hline $3.772 \mathrm{E}+06$ & 69 & & & \\
\hline $3.679 \mathrm{E}+06$ & 70 & & & \\
\hline $3.588 \mathrm{E}+06$ & 71 & & & \\
\hline $3.499 \mathrm{E}+06$ & 72 & & & \\
\hline $3.413 \mathrm{E}+06$ & 73 & & & \\
\hline $3.329 \mathrm{E}+06$ & 74 & & & \\
\hline $3.247 \mathrm{E}+06$ & 75 & & & \\
\hline $3.166 \mathrm{E}+06$ & 76 & & & \\
\hline $3.080 \mathrm{E}+06$ & 77 & & & \\
\hline $3.000 \mathrm{E}+06$ & 78 & \multirow{8}{*}{12} & & 5 \\
\hline $2.932 \mathrm{E}+06$ & 79 & & \multirow[t]{8}{*}{6} & \\
\hline $2.865 \mathrm{E}+06$ & 80 & & & \\
\hline $2.794 \mathrm{E}+06$ & 81 & & & \\
\hline $2.725 \mathrm{E}+06$ & 82 & & & \\
\hline $2.658 \mathrm{E}+06$ & 83 & & & \\
\hline $2.592 \mathrm{E}+06$ & 84 & & & \\
\hline $2.535 \mathrm{E}+06$ & 85 & & & \\
\hline $2.479 \mathrm{E}+06$ & 86 & \multirow[t]{4}{*}{13} & & 6 \\
\hline $2.466 \mathrm{E}+06$ & 87 & & \multirow[t]{4}{*}{7} & \\
\hline $2.385 \mathrm{E}+06$ & 88 & & & \\
\hline $2.365 \mathrm{E}+06$ & 89 & & & \\
\hline $2.354 \mathrm{E}+06$ & 90 & \multirow[t]{9}{*}{14} & & 7 \\
\hline $2.307 \mathrm{E}+06$ & 91 & & \multirow[t]{9}{*}{8} & \\
\hline $2.231 \mathrm{E}+06$ & 92 & & & \\
\hline $2.176 \mathrm{E}+06$ & 93 & & & \\
\hline $2.123 \mathrm{E}+06$ & 94 & & & \\
\hline $2.070 \mathrm{E}+06$ & 95 & & & \\
\hline $2.019 \mathrm{E}+06$ & 96 & & & \\
\hline $1.969 \mathrm{E}+06$ & 97 & & & \\
\hline $1.921 \mathrm{E}+06$ & 98 & & & \\
\hline $1.850 \mathrm{E}+06$ & 99 & 15 & & 8 \\
\hline
\end{tabular}




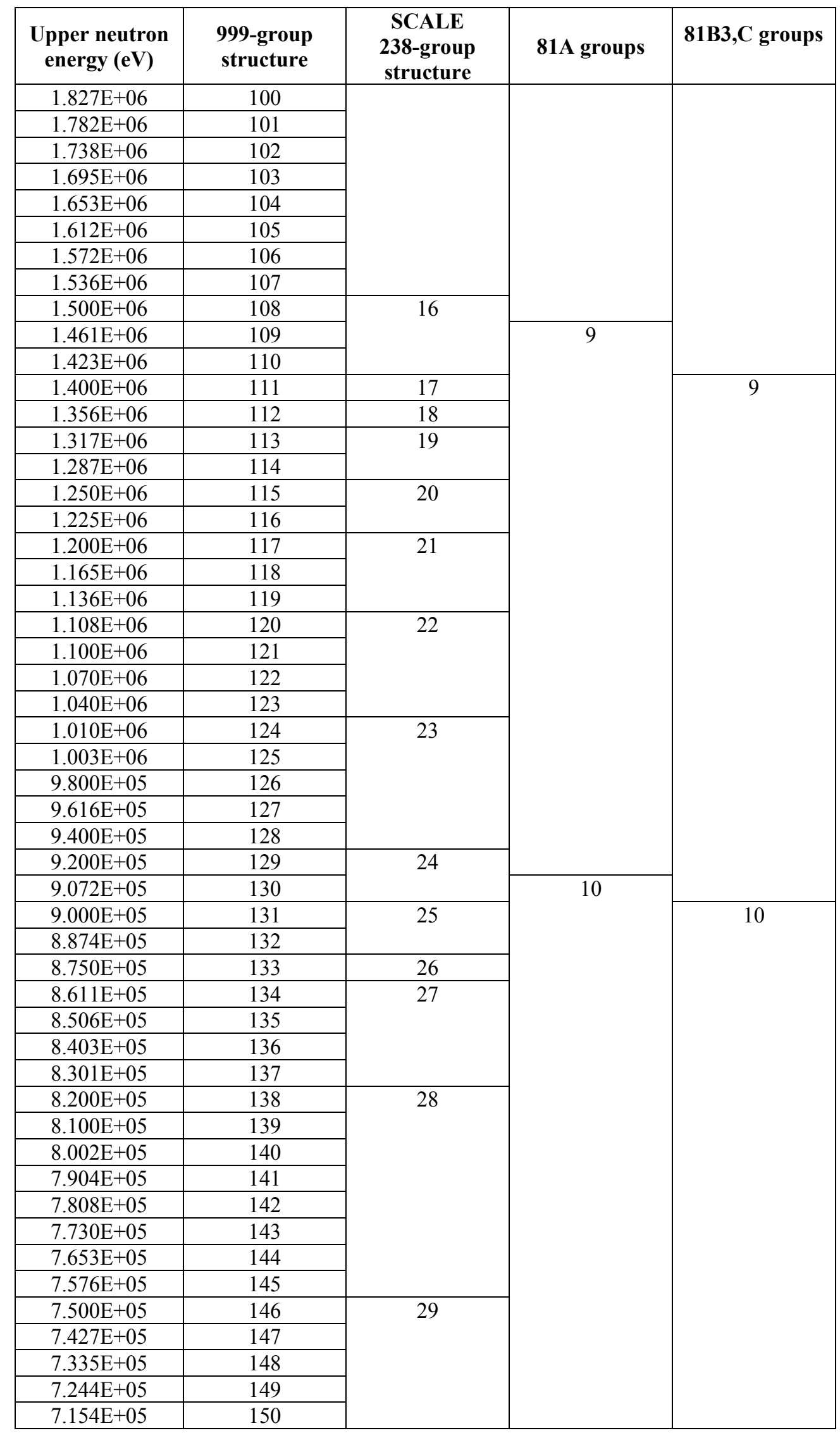




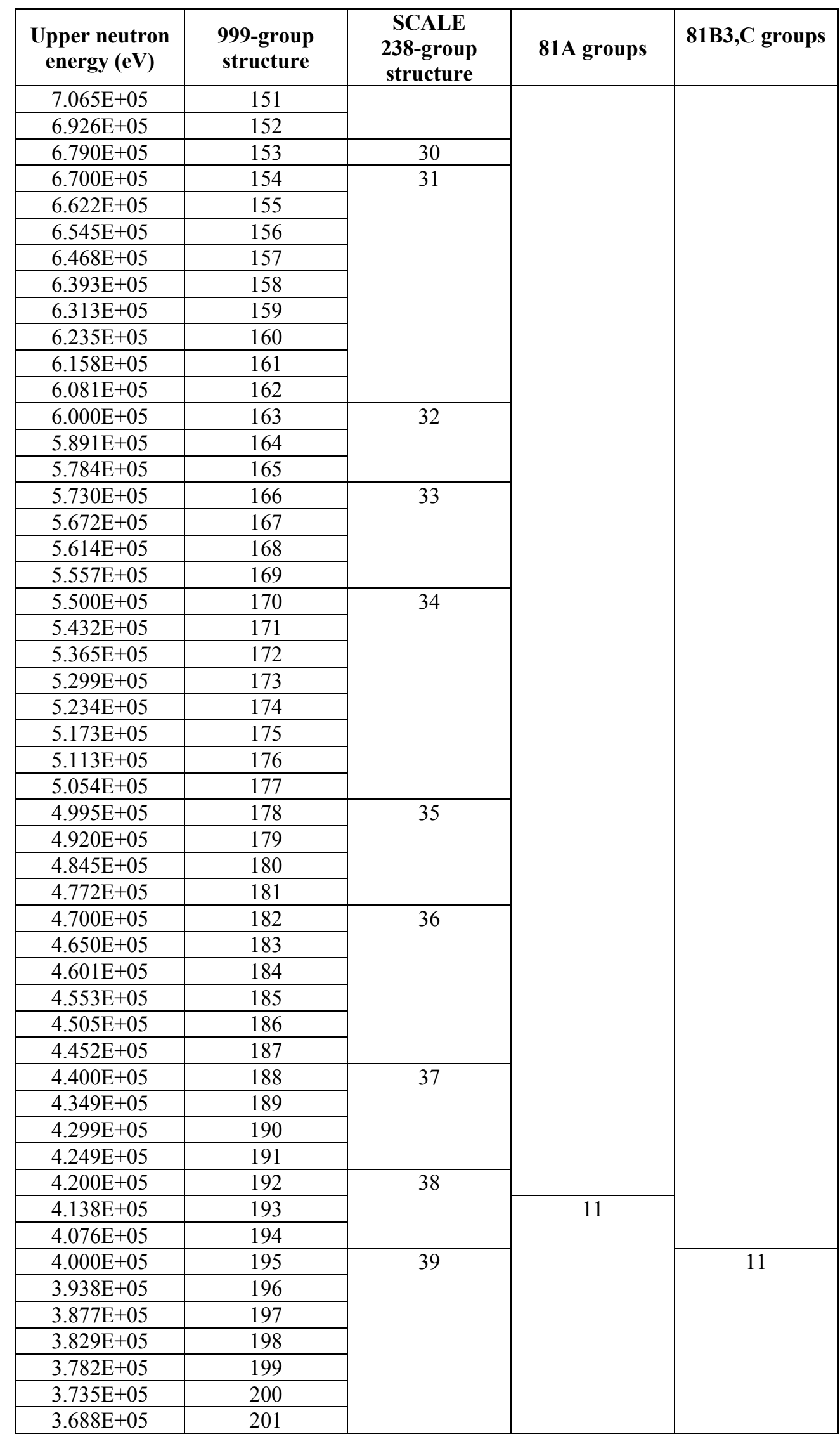




\begin{tabular}{|c|c|c|c|c|}
\hline $\begin{array}{l}\text { Upper neutron } \\
\text { energy }(\mathrm{eV})\end{array}$ & $\begin{array}{c}\text { 999-group } \\
\text { structure }\end{array}$ & $\begin{array}{c}\text { SCALE } \\
\text { 238-group } \\
\text { structure }\end{array}$ & 81A groups & $81 \mathrm{~B} 3, \mathrm{C}$ groups \\
\hline $3.643 \mathrm{E}+05$ & 202 & \multirow{26}{*}{40} & & \\
\hline $3.597 \mathrm{E}+05$ & 203 & & & \\
\hline $3.553 \mathrm{E}+05$ & 204 & & & \\
\hline $3.508 \mathrm{E}+05$ & 205 & & & \\
\hline $3.465 \mathrm{E}+05$ & 206 & & & \\
\hline $3.422 \mathrm{E}+05$ & 207 & & & \\
\hline $3.379 \mathrm{E}+05$ & 208 & & & \\
\hline $3.337 \mathrm{E}+05$ & 209 & & & \\
\hline $3.300 \mathrm{E}+05$ & 210 & & & \\
\hline $3.264 \mathrm{E}+05$ & 211 & & & \\
\hline $3.228 \mathrm{E}+05$ & 212 & & & \\
\hline $3.192 \mathrm{E}+05$ & 213 & & & \\
\hline $3.157 \mathrm{E}+05$ & 214 & & & \\
\hline $3.122 \mathrm{E}+05$ & 215 & & & \\
\hline $3.088 \mathrm{E}+05$ & 216 & & & \\
\hline $3.053 \mathrm{E}+05$ & 217 & & & \\
\hline $3.020 \mathrm{E}+05$ & 218 & & & \\
\hline $2.985 \mathrm{E}+05$ & 219 & & & \\
\hline $2.972 \mathrm{E}+05$ & 220 & & & \\
\hline $2.945 \mathrm{E}+05$ & 221 & & & \\
\hline $2.909 \mathrm{E}+05$ & 222 & & & \\
\hline $2.873 \mathrm{E}+05$ & 223 & & & \\
\hline $2.837 \mathrm{E}+05$ & 224 & & & \\
\hline $2.802 \mathrm{E}+05$ & 225 & & & \\
\hline $2.767 \mathrm{E}+05$ & 226 & & & \\
\hline $2.732 \mathrm{E}+05$ & 227 & & & \\
\hline $2.700 \mathrm{E}+05$ & 228 & \multirow[t]{25}{*}{41} & & \\
\hline $2.670 \mathrm{E}+05$ & 229 & & & \\
\hline $2.641 \mathrm{E}+05$ & 230 & & & \\
\hline $2.612 \mathrm{E}+05$ & 231 & & & \\
\hline $2.584 \mathrm{E}+05$ & 232 & & & \\
\hline $2.555 \mathrm{E}+05$ & 233 & & & \\
\hline $2.527 \mathrm{E}+05$ & 234 & & & \\
\hline $2.500 \mathrm{E}+05$ & 235 & & & \\
\hline $2.472 \mathrm{E}+05$ & 236 & & & \\
\hline $2.442 \mathrm{E}+05$ & 237 & & & \\
\hline $2.411 \mathrm{E}+05$ & 238 & & & \\
\hline $2.381 \mathrm{E}+05$ & 239 & & & \\
\hline $2.352 \mathrm{E}+05$ & 240 & & & \\
\hline $2.323 \mathrm{E}+05$ & 241 & & & \\
\hline $2.294 \mathrm{E}+05$ & 242 & & & \\
\hline $2.265 \mathrm{E}+05$ & 243 & & & \\
\hline $2.237 \mathrm{E}+05$ & 244 & & & \\
\hline $2.209 \mathrm{E}+05$ & 245 & & & \\
\hline $2.182 \mathrm{E}+05$ & 246 & & & \\
\hline $2.155 \mathrm{E}+05$ & 247 & & & \\
\hline $2.128 \mathrm{E}+05$ & 248 & & & \\
\hline $2.102 \mathrm{E}+05$ & 249 & & & \\
\hline $2.076 \mathrm{E}+05$ & 250 & & & \\
\hline $2.050 \mathrm{E}+05$ & 251 & & & \\
\hline $2.024 \mathrm{E}+05$ & 252 & & & \\
\hline
\end{tabular}




\begin{tabular}{|c|c|c|c|c|}
\hline $\begin{array}{c}\text { Upper neutron } \\
\text { energy }(\mathrm{eV})\end{array}$ & $\begin{array}{c}\text { 999-group } \\
\text { structure }\end{array}$ & $\begin{array}{c}\text { SCALE } \\
\text { 238-group } \\
\text { structure }\end{array}$ & $81 \mathrm{~A}$ groups & $81 \mathrm{~B} 3, \mathrm{C}$ groups \\
\hline $2.000 \mathrm{E}+05$ & 253 & \multirow[t]{22}{*}{42} & & \\
\hline $1.962 \mathrm{E}+05$ & 254 & & & \\
\hline $1.926 \mathrm{E}+05$ & 255 & & & \\
\hline $1.902 \mathrm{E}+05$ & 256 & & & \\
\hline $1.878 \mathrm{E}+05$ & 257 & & & \\
\hline $1.855 \mathrm{E}+05$ & 258 & & & \\
\hline $1.832 \mathrm{E}+05$ & 259 & & & \\
\hline $1.809 \mathrm{E}+05$ & 260 & & & \\
\hline $1.786 \mathrm{E}+05$ & 261 & & & \\
\hline $1.764 \mathrm{E}+05$ & 262 & & & \\
\hline $1.742 \mathrm{E}+05$ & 263 & & & \\
\hline $1.721 \mathrm{E}+05$ & 264 & & & \\
\hline $1.699 \mathrm{E}+05$ & 265 & & & \\
\hline $1.678 \mathrm{E}+05$ & 266 & & & \\
\hline $1.657 \mathrm{E}+05$ & 267 & & & \\
\hline $1.637 \mathrm{E}+05$ & 268 & & & \\
\hline $1.616 \mathrm{E}+05$ & 269 & & & \\
\hline $1.596 \mathrm{E}+05$ & 270 & & & \\
\hline $1.576 \mathrm{E}+05$ & 271 & & & \\
\hline $1.557 \mathrm{E}+05$ & 272 & & & \\
\hline $1.538 \mathrm{E}+05$ & 273 & & & \\
\hline $1.519 \mathrm{E}+05$ & 274 & & & \\
\hline $1.500 \mathrm{E}+05$ & 275 & \multirow[t]{13}{*}{43} & & \\
\hline $1.481 \mathrm{E}+05$ & 276 & & & \\
\hline $1.463 \mathrm{E}+05$ & 277 & & & \\
\hline $1.445 \mathrm{E}+05$ & 278 & & & \\
\hline $1.426 \mathrm{E}+05$ & 279 & & & \\
\hline $1.409 \mathrm{E}+05$ & 280 & & & \\
\hline $1.391 \mathrm{E}+05$ & 281 & & & \\
\hline $1.374 \mathrm{E}+05$ & 282 & & & \\
\hline $1.357 \mathrm{E}+05$ & 283 & & & \\
\hline $1.340 \mathrm{E}+05$ & 284 & & & \\
\hline $1.323 \mathrm{E}+05$ & 285 & & & \\
\hline $1.307 \mathrm{E}+05$ & 286 & & & \\
\hline $1.291 \mathrm{E}+05$ & 287 & & & \\
\hline $1.283 \mathrm{E}+05$ & 288 & \multirow[t]{16}{*}{44} & & \\
\hline $1.269 \mathrm{E}+05$ & 289 & & \multirow[t]{15}{*}{12} & \\
\hline $1.255 \mathrm{E}+05$ & 290 & & & \\
\hline $1.241 \mathrm{E}+05$ & 291 & & & \\
\hline $1.228 \mathrm{E}+05$ & 292 & & & \\
\hline $1.213 \mathrm{E}+05$ & 293 & & & \\
\hline $1.197 \mathrm{E}+05$ & 294 & & & \\
\hline $1.183 \mathrm{E}+05$ & 295 & & & \\
\hline $1.168 \mathrm{E}+05$ & 296 & & & \\
\hline $1.153 \mathrm{E}+05$ & 297 & & & \\
\hline $1.139 \mathrm{E}+05$ & 298 & & & \\
\hline $1.125 \mathrm{E}+05$ & 299 & & & \\
\hline $1.111 \mathrm{E}+05$ & 300 & & & \\
\hline $1.096 \mathrm{E}+05$ & 301 & & & \\
\hline $1.082 \mathrm{E}+05$ & 302 & & & \\
\hline $1.068 \mathrm{E}+05$ & 303 & & & \\
\hline
\end{tabular}




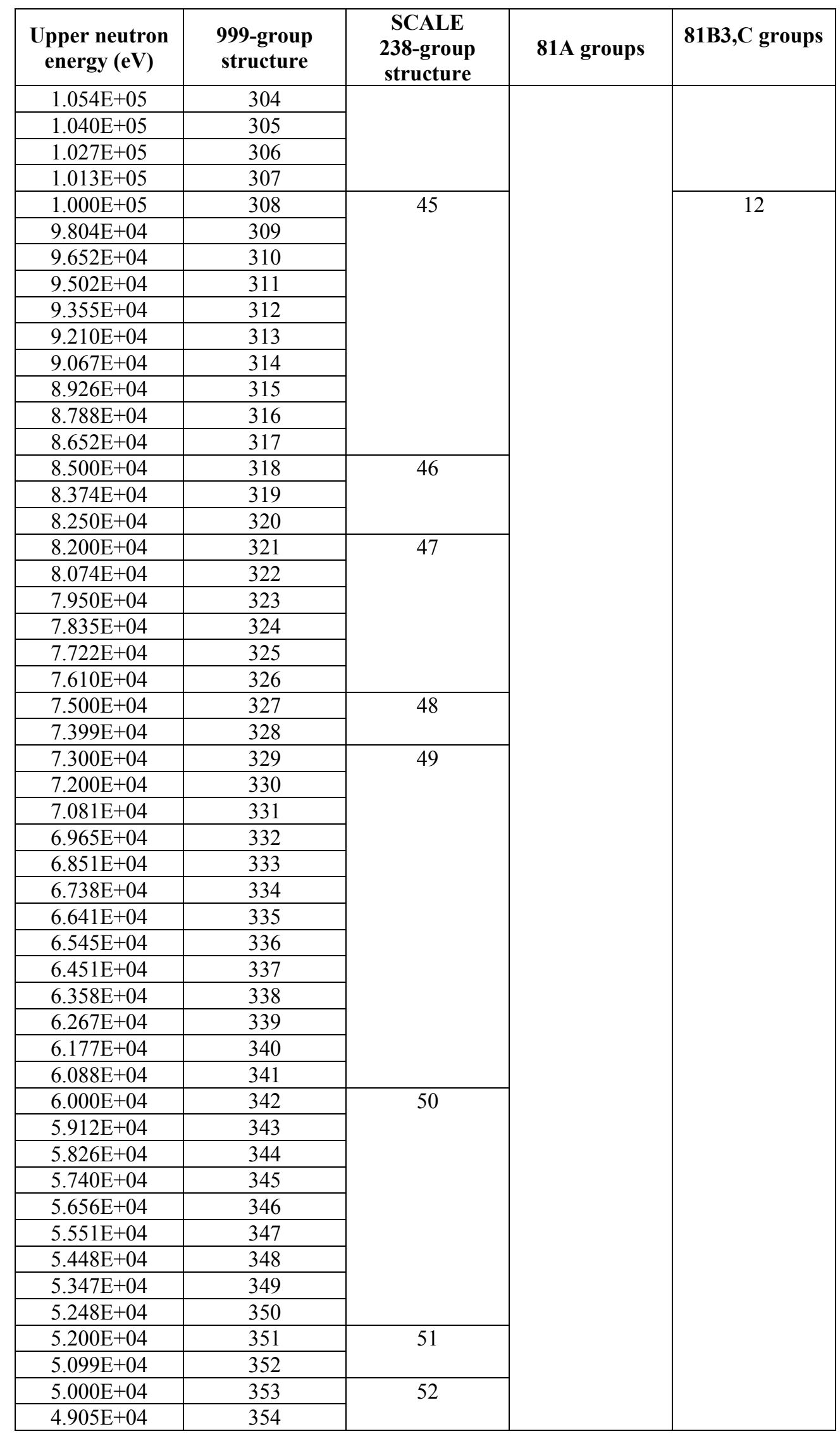




\begin{tabular}{|c|c|c|c|c|}
\hline $\begin{array}{c}\text { Upper neutron } \\
\text { energy }(\mathrm{eV})\end{array}$ & $\begin{array}{c}\text { 999-group } \\
\text { structure }\end{array}$ & $\begin{array}{c}\text { SCALE } \\
\text { 238-group } \\
\text { structure }\end{array}$ & $81 \mathrm{~A}$ groups & $81 \mathrm{~B} 3, \mathrm{C}$ groups \\
\hline $4.812 \mathrm{E}+04$ & 355 & \multirow{36}{*}{53} & & \\
\hline $4.721 \mathrm{E}+04$ & 356 & & & \\
\hline $4.631 \mathrm{E}+04$ & 357 & & & \\
\hline $4.565 \mathrm{E}+04$ & 358 & & & \\
\hline $4.500 \mathrm{E}+04$ & 359 & & & \\
\hline $4.446 \mathrm{E}+04$ & 360 & & & \\
\hline $4.393 \mathrm{E}+04$ & 361 & & & \\
\hline $4.340 \mathrm{E}+04$ & 362 & & & \\
\hline $4.288 \mathrm{E}+04$ & 363 & & & \\
\hline $4.237 \mathrm{E}+04$ & 364 & & & \\
\hline $4.186 \mathrm{E}+04$ & 365 & & & \\
\hline $4.136 \mathrm{E}+04$ & 366 & & & \\
\hline $4.087 \mathrm{E}+04$ & 367 & & & \\
\hline $4.042 \mathrm{E}+04$ & 368 & & & \\
\hline $3.998 \mathrm{E}+04$ & 369 & & & \\
\hline $3.955 \mathrm{E}+04$ & 370 & & & \\
\hline $3.912 \mathrm{E}+04$ & 371 & & & \\
\hline $3.869 \mathrm{E}+04$ & 372 & & & \\
\hline $3.827 \mathrm{E}+04$ & 373 & & & \\
\hline $3.786 \mathrm{E}+04$ & 374 & & & \\
\hline $3.744 \mathrm{E}+04$ & 375 & & & \\
\hline $3.704 \mathrm{E}+04$ & 376 & & & \\
\hline $3.663 \mathrm{E}+04$ & 377 & & & \\
\hline $3.624 \mathrm{E}+04$ & 378 & & & \\
\hline $3.584 \mathrm{E}+04$ & 379 & & & \\
\hline $3.545 \mathrm{E}+04$ & 380 & & & \\
\hline $3.507 \mathrm{E}+04$ & 381 & & & \\
\hline $3.468 \mathrm{E}+04$ & 382 & & & \\
\hline $3.431 \mathrm{E}+04$ & 383 & & & \\
\hline $3.367 \mathrm{E}+04$ & 384 & & & \\
\hline $3.304 \mathrm{E}+04$ & 385 & & & \\
\hline $3.243 \mathrm{E}+04$ & 386 & & & \\
\hline $3.183 \mathrm{E}+04$ & 387 & & & \\
\hline $3.136 \mathrm{E}+04$ & 388 & & & \\
\hline $3.090 \mathrm{E}+04$ & 389 & & & \\
\hline $3.045 \mathrm{E}+04$ & 390 & & & \\
\hline $3.000 \mathrm{E}+04$ & 391 & \multirow[t]{14}{*}{54} & & \\
\hline $2.962 \mathrm{E}+04$ & 392 & & \multirow[t]{7}{*}{13} & \\
\hline $2.924 \mathrm{E}+04$ & 393 & & & \\
\hline $2.887 \mathrm{E}+04$ & 394 & & & \\
\hline $2.850 \mathrm{E}+04$ & 395 & & & \\
\hline $2.812 \mathrm{E}+04$ & 396 & & & \\
\hline $2.774 \mathrm{E}+04$ & 397 & & & \\
\hline $2.737 \mathrm{E}+04$ & 398 & & & \\
\hline $2.700 \mathrm{E}+04$ & 399 & & \multirow[t]{7}{*}{14} & \\
\hline $2.653 \mathrm{E}+04$ & 400 & & & \\
\hline $2.606 \mathrm{E}+04$ & 401 & & & \\
\hline $2.580 \mathrm{E}+04$ & 402 & & & \\
\hline $2.552 \mathrm{E}+04$ & 403 & & & \\
\hline $2.520 \mathrm{E}+04$ & 404 & & & \\
\hline $2.500 \mathrm{E}+04$ & 405 & 55 & & 13 \\
\hline
\end{tabular}




\begin{tabular}{|c|c|c|c|c|}
\hline $\begin{array}{l}\text { Upper neutron } \\
\text { energy }(\mathrm{eV})\end{array}$ & $\begin{array}{c}\text { 999-group } \\
\text { structure }\end{array}$ & $\begin{array}{c}\text { SCALE } \\
\text { 238-group } \\
\text { structure }\end{array}$ & $81 \mathrm{~A}$ groups & $81 B 3, C$ groups \\
\hline $2.479 \mathrm{E}+04$ & 406 & & \multirow[t]{32}{*}{15} & \\
\hline $2.450 \mathrm{E}+04$ & 407 & & & \\
\hline $2.418 \mathrm{E}+04$ & 408 & & & \\
\hline $2.388 \mathrm{E}+04$ & 409 & & & \\
\hline $2.358 \mathrm{E}+04$ & 410 & & & \\
\hline $2.314 \mathrm{E}+04$ & 411 & & & \\
\hline $2.271 \mathrm{E}+04$ & 412 & & & \\
\hline $2.229 \mathrm{E}+04$ & 413 & & & \\
\hline $2.188 \mathrm{E}+04$ & 414 & & & \\
\hline $2.139 \mathrm{E}+04$ & 415 & & & \\
\hline $2.092 \mathrm{E}+04$ & 416 & & & \\
\hline $2.045 \mathrm{E}+04$ & 417 & & & \\
\hline $2.000 \mathrm{E}+04$ & 418 & & & \\
\hline $1.965 \mathrm{E}+04$ & 419 & & & \\
\hline $1.931 \mathrm{E}+04$ & 420 & & & \\
\hline $1.900 \mathrm{E}+04$ & 421 & & & \\
\hline $1.870 \mathrm{E}+04$ & 422 & & & \\
\hline $1.841 \mathrm{E}+04$ & 423 & & & \\
\hline $1.812 \mathrm{E}+04$ & 424 & & & \\
\hline $1.783 \mathrm{E}+04$ & 425 & & & \\
\hline $1.755 \mathrm{E}+04$ & 426 & & & \\
\hline $1.727 \mathrm{E}+04$ & 427 & & & \\
\hline $1.700 \mathrm{E}+04$ & 428 & \multirow[t]{16}{*}{56} & & \multirow[t]{16}{*}{14} \\
\hline $1.674 \mathrm{E}+04$ & 429 & & & \\
\hline $1.649 \mathrm{E}+04$ & 430 & & & \\
\hline $1.623 \mathrm{E}+04$ & 431 & & & \\
\hline $1.599 \mathrm{E}+04$ & 432 & & & \\
\hline $1.574 \mathrm{E}+04$ & 433 & & & \\
\hline $1.550 \mathrm{E}+04$ & 434 & & & \\
\hline $1.527 \mathrm{E}+04$ & 435 & & & \\
\hline $1.503 \mathrm{E}+04$ & 436 & & & \\
\hline $1.476 \mathrm{E}+04$ & 437 & & & \\
\hline $1.450 \mathrm{E}+04$ & 438 & & \multirow[t]{19}{*}{16} & \\
\hline $1.424 \mathrm{E}+04$ & 439 & & & \\
\hline $1.398 \mathrm{E}+04$ & 440 & & & \\
\hline $1.373 \mathrm{E}+04$ & 441 & & & \\
\hline $1.348 \mathrm{E}+04$ & 442 & & & \\
\hline $1.324 \mathrm{E}+04$ & 443 & & & \\
\hline $1.300 \mathrm{E}+04$ & 444 & \multirow[t]{13}{*}{57} & & \multirow[t]{12}{*}{15} \\
\hline $1.266 \mathrm{E}+04$ & 445 & & & \\
\hline $1.234 \mathrm{E}+04$ & 446 & & & \\
\hline $1.202 \mathrm{E}+04$ & 447 & & & \\
\hline $1.171 \mathrm{E}+04$ & 448 & & & \\
\hline $1.142 \mathrm{E}+04$ & 449 & & & \\
\hline $1.114 \mathrm{E}+04$ & 450 & & & \\
\hline $1.086 \mathrm{E}+04$ & 451 & & & \\
\hline $1.060 \mathrm{E}+04$ & 452 & & & \\
\hline $1.031 \mathrm{E}+04$ & 453 & & & \\
\hline $1.003 \mathrm{E}+04$ & 454 & & & \\
\hline $9.763 \mathrm{E}+03$ & 455 & & & \\
\hline $9.500 \mathrm{E}+03$ & 456 & & & 16 \\
\hline
\end{tabular}




\begin{tabular}{|c|c|c|c|c|}
\hline $\begin{array}{c}\text { Upper neutron } \\
\text { energy }(e V)\end{array}$ & $\begin{array}{c}\text { 999-group } \\
\text { structure }\end{array}$ & $\begin{array}{c}\text { SCALE } \\
\text { 238-group } \\
\text { structure }\end{array}$ & 81A groups & $81 \mathrm{~B} 3, \mathrm{C}$ groups \\
\hline $9.307 \mathrm{E}+03$ & 457 & \multirow{25}{*}{ structuit } & & \\
\hline $9.119 \mathrm{E}+03$ & 458 & & & \\
\hline $8.975 \mathrm{E}+03$ & 459 & & & \\
\hline $8.834 \mathrm{E}+03$ & 460 & & & \\
\hline $8.694 \mathrm{E}+03$ & 461 & & & \\
\hline $8.557 \mathrm{E}+03$ & 462 & & & \\
\hline $8.422 \mathrm{E}+03$ & 463 & & & \\
\hline $8.289 \mathrm{E}+03$ & 464 & & & \\
\hline $8.159 \mathrm{E}+03$ & 465 & & & \\
\hline $8.030 \mathrm{E}+03$ & 466 & & & \\
\hline $7.908 \mathrm{E}+03$ & 467 & & & \\
\hline $7.787 \mathrm{E}+03$ & 468 & & & \\
\hline $7.669 \mathrm{E}+03$ & 469 & & & \\
\hline $7.552 \mathrm{E}+03$ & 470 & & & \\
\hline $7.437 \mathrm{E}+03$ & 471 & & & \\
\hline $7.323 \mathrm{E}+03$ & 472 & & & \\
\hline $7.212 \mathrm{E}+03$ & 473 & & & \\
\hline $7.102 \mathrm{E}+03$ & 474 & & & \\
\hline $6.954 \mathrm{E}+03$ & 475 & & & \\
\hline $6.809 \mathrm{E}+03$ & 476 & & & \\
\hline $6.667 \mathrm{E}+03$ & 477 & & & \\
\hline $6.528 \mathrm{E}+03$ & 478 & & & \\
\hline $6.392 \mathrm{E}+03$ & 479 & & & \\
\hline $6.258 \mathrm{E}+03$ & 480 & & & \\
\hline $6.128 \mathrm{E}+03$ & 481 & & & \\
\hline $6.000 \mathrm{E}+03$ & 482 & \multirow{18}{*}{60} & & \\
\hline $5.879 \mathrm{E}+03$ & 483 & & & \\
\hline $5.761 \mathrm{E}+03$ & 484 & & & \\
\hline $5.645 \mathrm{E}+03$ & 485 & & & \\
\hline $5.531 \mathrm{E}+03$ & 486 & & & \\
\hline $5.400 \mathrm{E}+03$ & 487 & & & \\
\hline $5.250 \mathrm{E}+03$ & 488 & & & \\
\hline $5.100 \mathrm{E}+03$ & 489 & & & \\
\hline $4.960 \mathrm{E}+03$ & 490 & & & \\
\hline $4.850 \mathrm{E}+03$ & 491 & & & \\
\hline $4.740 \mathrm{E}+03$ & 492 & & & \\
\hline $4.620 \mathrm{E}+03$ & 493 & & & \\
\hline $4.500 \mathrm{E}+03$ & 494 & & & \\
\hline $4.400 \mathrm{E}+03$ & 495 & & & \\
\hline $4.307 \mathrm{E}+03$ & 496 & & & \\
\hline $4.202 \mathrm{E}+03$ & 497 & & & \\
\hline $4.099 \mathrm{E}+03$ & 498 & & & \\
\hline $3.998 \mathrm{E}+03$ & 499 & & & \\
\hline $3.900 \mathrm{E}+03$ & 500 & \multirow[t]{2}{*}{61} & & \\
\hline $3.819 \mathrm{E}+03$ & 501 & & & \\
\hline $3.740 \mathrm{E}+03$ & 502 & \multirow[t]{6}{*}{62} & & \\
\hline $3.707 \mathrm{E}+03$ & 503 & & \multirow[t]{5}{*}{17} & \\
\hline $3.616 \mathrm{E}+03$ & 504 & & & \\
\hline $3.527 \mathrm{E}+03$ & 505 & & & \\
\hline $3.440 \mathrm{E}+03$ & 506 & & & \\
\hline $3.355 \mathrm{E}+03$ & 507 & & & \\
\hline
\end{tabular}




\begin{tabular}{|c|c|c|c|c|}
\hline $\begin{array}{l}\text { Upper neutron } \\
\text { energy }(\mathrm{eV})\end{array}$ & $\begin{array}{l}\text { 999-group } \\
\text { structure }\end{array}$ & $\begin{array}{c}\text { SCALE } \\
\text { 238-group } \\
\text { structure }\end{array}$ & 81 A groups & 81B3,C groups \\
\hline $3.272 \mathrm{E}+03$ & 508 & \multirow{11}{*}{ Dercente } & & \\
\hline $3.191 \mathrm{E}+03$ & 509 & & & \\
\hline $3.112 \mathrm{E}+03$ & 510 & & & \\
\hline $3.035 \mathrm{E}+03$ & 511 & & & \\
\hline $3.000 \mathrm{E}+03$ & 512 & & \multirow[t]{8}{*}{18} & \multirow[t]{7}{*}{17} \\
\hline $2.935 \mathrm{E}+03$ & 513 & & & \\
\hline $2.871 \mathrm{E}+03$ & 514 & & & \\
\hline $2.808 \mathrm{E}+03$ & 515 & & & \\
\hline $2.747 \mathrm{E}+03$ & 516 & & & \\
\hline $2.679 \mathrm{E}+03$ & 517 & & & \\
\hline $2.613 \mathrm{E}+03$ & 518 & & & \\
\hline $2.580 \mathrm{E}+03$ & 519 & \multirow[t]{6}{*}{64} & & \multirow[t]{6}{*}{18} \\
\hline $2.532 \mathrm{E}+03$ & 520 & & \multirow{6}{*}{19} & \\
\hline $2.485 \mathrm{E}+03$ & 521 & & & \\
\hline $2.435 \mathrm{E}+03$ & 522 & & & \\
\hline $2.386 \mathrm{E}+03$ & 523 & & & \\
\hline $2.337 \mathrm{E}+03$ & 524 & & & \\
\hline $2.290 \mathrm{E}+03$ & 525 & \multirow{2}{*}{65} & & \multirow[t]{2}{*}{19} \\
\hline $2.249 \mathrm{E}+03$ & 526 & & \multirow[t]{2}{*}{20} & \\
\hline $2.200 \mathrm{E}+03$ & 527 & \multirow[t]{12}{*}{66} & & \multirow[t]{12}{*}{20} \\
\hline $2.158 \mathrm{E}+03$ & 528 & & \multirow[t]{31}{*}{21} & \\
\hline $2.116 \mathrm{E}+03$ & 529 & & & \\
\hline $2.075 \mathrm{E}+03$ & 530 & & & \\
\hline $2.035 \mathrm{E}+03$ & 531 & & & \\
\hline $2.004 \mathrm{E}+03$ & 532 & & & \\
\hline $1.973 \mathrm{E}+03$ & 533 & & & \\
\hline $1.943 \mathrm{E}+03$ & 534 & & & \\
\hline $1.914 \mathrm{E}+03$ & 535 & & & \\
\hline $1.885 \mathrm{E}+03$ & 536 & & & \\
\hline $1.856 \mathrm{E}+03$ & 537 & & & \\
\hline $1.828 \mathrm{E}+03$ & 538 & & & \\
\hline $1.800 \mathrm{E}+03$ & 539 & \multirow[t]{9}{*}{67} & & \multirow[t]{20}{*}{21} \\
\hline $1.772 \mathrm{E}+03$ & 540 & & & \\
\hline $1.744 \mathrm{E}+03$ & 541 & & & \\
\hline $1.716 \mathrm{E}+03$ & 542 & & & \\
\hline $1.689 \mathrm{E}+03$ & 543 & & & \\
\hline $1.662 \mathrm{E}+03$ & 544 & & & \\
\hline $1.636 \mathrm{E}+03$ & 545 & & & \\
\hline $1.610 \mathrm{E}+03$ & 546 & & & \\
\hline $1.585 \mathrm{E}+03$ & 547 & & & \\
\hline $1.550 \mathrm{E}+03$ & 548 & \multirow[t]{2}{*}{68} & & \\
\hline $1.525 \mathrm{E}+03$ & 549 & & & \\
\hline $1.500 \mathrm{E}+03$ & 550 & \multirow[t]{9}{*}{69} & & \\
\hline $1.482 \mathrm{E}+03$ & 551 & & & \\
\hline $1.464 \mathrm{E}+03$ & 552 & & & \\
\hline $1.446 \mathrm{E}+03$ & 553 & & & \\
\hline $1.429 \mathrm{E}+03$ & 554 & & & \\
\hline $1.411 \mathrm{E}+03$ & 555 & & & \\
\hline $1.394 \mathrm{E}+03$ & 556 & & & \\
\hline $1.377 \mathrm{E}+03$ & 557 & & & \\
\hline $1.361 \mathrm{E}+03$ & 558 & & & \\
\hline
\end{tabular}




\begin{tabular}{|c|c|c|c|c|}
\hline $\begin{array}{c}\text { Upper neutron } \\
\text { energy }(\mathrm{eV})\end{array}$ & $\begin{array}{l}\text { 999-group } \\
\text { structure }\end{array}$ & $\begin{array}{c}\text { SCALE } \\
\text { 238-group } \\
\text { structure }\end{array}$ & 81A groups & $81 \mathrm{~B} 3, \mathrm{C}$ groups \\
\hline $1.344 \mathrm{E}+03$ & 559 & \multirow{29}{*}{70} & & \\
\hline $1.328 \mathrm{E}+03$ & 560 & & \multirow[t]{50}{*}{22} & \\
\hline $1.312 \mathrm{E}+03$ & 561 & & & \\
\hline $1.296 \mathrm{E}+03$ & 562 & & & \\
\hline $1.280 \mathrm{E}+03$ & 563 & & & \\
\hline $1.265 \mathrm{E}+03$ & 564 & & & \\
\hline $1.249 \mathrm{E}+03$ & 565 & & & \\
\hline $1.234 \mathrm{E}+03$ & 566 & & & \\
\hline $1.213 \mathrm{E}+03$ & 567 & & & \\
\hline $1.191 \mathrm{E}+03$ & 568 & & & \\
\hline $1.171 \mathrm{E}+03$ & 569 & & & \\
\hline $1.150 \mathrm{E}+03$ & 570 & & & \\
\hline $1.137 \mathrm{E}+03$ & 571 & & & \\
\hline $1.125 \mathrm{E}+03$ & 572 & & & \\
\hline $1.112 \mathrm{E}+03$ & 573 & & & \\
\hline $1.100 \mathrm{E}+03$ & 574 & & & \\
\hline $1.087 \mathrm{E}+03$ & 575 & & & \\
\hline $1.075 \mathrm{E}+03$ & 576 & & & \\
\hline $1.063 \mathrm{E}+03$ & 577 & & & \\
\hline $1.051 \mathrm{E}+03$ & 578 & & & \\
\hline $1.040 \mathrm{E}+03$ & 579 & & & \\
\hline $1.028 \mathrm{E}+03$ & 580 & & & \\
\hline $1.017 \mathrm{E}+03$ & 581 & & & \\
\hline $1.005 \mathrm{E}+03$ & 582 & & & \\
\hline $9.940 \mathrm{E}+02$ & 583 & & & \\
\hline $9.829 \mathrm{E}+02$ & 584 & & & \\
\hline $9.720 \mathrm{E}+02$ & 585 & & & \\
\hline $9.611 \mathrm{E}+02$ & 586 & & & \\
\hline $9.555 \mathrm{E}+02$ & 587 & & & \\
\hline $9.500 \mathrm{E}+02$ & 588 & \multirow[t]{22}{*}{71} & & \multirow[t]{22}{*}{22} \\
\hline $9.360 \mathrm{E}+02$ & 589 & & & \\
\hline $9.221 \mathrm{E}+02$ & 590 & & & \\
\hline $9.085 \mathrm{E}+02$ & 591 & & & \\
\hline $8.950 \mathrm{E}+02$ & 592 & & & \\
\hline $8.818 \mathrm{E}+02$ & 593 & & & \\
\hline $8.688 \mathrm{E}+02$ & 594 & & & \\
\hline $8.559 \mathrm{E}+02$ & 595 & & & \\
\hline $8.433 \mathrm{E}+02$ & 596 & & & \\
\hline $8.308 \mathrm{E}+02$ & 597 & & & \\
\hline $8.185 \mathrm{E}+02$ & 598 & & & \\
\hline $8.064 \mathrm{E}+02$ & 599 & & & \\
\hline $7.945 \mathrm{E}+02$ & 600 & & & \\
\hline $7.827 \mathrm{E}+02$ & 601 & & & \\
\hline $7.712 \mathrm{E}+02$ & 602 & & & \\
\hline $7.598 \mathrm{E}+02$ & 603 & & & \\
\hline $7.485 \mathrm{E}+02$ & 604 & & & \\
\hline $7.400 \mathrm{E}+02$ & 605 & & & \\
\hline $7.316 \mathrm{E}+02$ & 606 & & & \\
\hline $7.232 \mathrm{E}+02$ & 607 & & & \\
\hline $7.150 \mathrm{E}+02$ & 608 & & & \\
\hline $7.069 \mathrm{E}+02$ & 609 & & & \\
\hline
\end{tabular}




\begin{tabular}{|c|c|c|c|c|}
\hline $\begin{array}{c}\text { Upper neutron } \\
\text { energy }(\mathrm{eV})\end{array}$ & $\begin{array}{l}\text { 999-group } \\
\text { structure }\end{array}$ & $\begin{array}{c}\text { SCALE } \\
\text { 238-group } \\
\text { structure }\end{array}$ & 81A groups & 81B3,C groups \\
\hline $6.988 \mathrm{E}+02$ & 610 & \multirow{4}{*}{72} & & \\
\hline $6.909 \mathrm{E}+02$ & 611 & & & \\
\hline $6.830 \mathrm{E}+02$ & 612 & & & \\
\hline $6.765 \mathrm{E}+02$ & 613 & & & \\
\hline $6.700 \mathrm{E}+02$ & 614 & \multirow[t]{12}{*}{73} & & \\
\hline $6.585 \mathrm{E}+02$ & 615 & & \multirow[t]{46}{*}{23} & \\
\hline $6.471 \mathrm{E}+02$ & 616 & & & \\
\hline $6.359 \mathrm{E}+02$ & 617 & & & \\
\hline $6.250 \mathrm{E}+02$ & 618 & & & \\
\hline $6.142 \mathrm{E}+02$ & 619 & & & \\
\hline $6.036 \mathrm{E}+02$ & 620 & & & \\
\hline $5.932 \mathrm{E}+02$ & 621 & & & \\
\hline $5.830 \mathrm{E}+02$ & 622 & & & \\
\hline $5.745 \mathrm{E}+02$ & 623 & & & \\
\hline $5.662 \mathrm{E}+02$ & 624 & & & \\
\hline $5.581 \mathrm{E}+02$ & 625 & & & \\
\hline $5.500 \mathrm{E}+02$ & 626 & \multirow{35}{*}{74} & & \multirow[t]{35}{*}{23} \\
\hline $5.435 \mathrm{E}+02$ & 627 & & & \\
\hline $5.370 \mathrm{E}+02$ & 628 & & & \\
\hline $5.306 \mathrm{E}+02$ & 629 & & & \\
\hline $5.243 \mathrm{E}+02$ & 630 & & & \\
\hline $5.180 \mathrm{E}+02$ & 631 & & & \\
\hline $5.118 \mathrm{E}+02$ & 632 & & & \\
\hline $5.057 \mathrm{E}+02$ & 633 & & & \\
\hline $4.997 \mathrm{E}+02$ & 634 & & & \\
\hline $4.937 \mathrm{E}+02$ & 635 & & & \\
\hline $4.879 \mathrm{E}+02$ & 636 & & & \\
\hline $4.821 \mathrm{E}+02$ & 637 & & & \\
\hline $4.763 \mathrm{E}+02$ & 638 & & & \\
\hline $4.706 \mathrm{E}+02$ & 639 & & & \\
\hline $4.650 \mathrm{E}+02$ & 640 & & & \\
\hline $4.595 \mathrm{E}+02$ & 641 & & & \\
\hline $4.540 \mathrm{E}+02$ & 642 & & & \\
\hline $4.470 \mathrm{E}+02$ & 643 & & & \\
\hline $4.400 \mathrm{E}+02$ & 644 & & & \\
\hline $4.332 \mathrm{E}+02$ & 645 & & & \\
\hline $4.265 \mathrm{E}+02$ & 646 & & & \\
\hline $4.199 \mathrm{E}+02$ & 647 & & & \\
\hline $4.134 \mathrm{E}+02$ & 648 & & & \\
\hline $4.070 \mathrm{E}+02$ & 649 & & & \\
\hline $4.007 \mathrm{E}+02$ & 650 & & & \\
\hline $3.944 \mathrm{E}+02$ & 651 & & & \\
\hline $3.883 \mathrm{E}+02$ & 652 & & & \\
\hline $3.823 \mathrm{E}+02$ & 653 & & & \\
\hline $3.764 \mathrm{E}+02$ & 654 & & & \\
\hline $3.705 \mathrm{E}+02$ & 655 & & & \\
\hline $3.648 \mathrm{E}+02$ & 656 & & & \\
\hline $3.591 \mathrm{E}+02$ & 657 & & & \\
\hline $3.536 \mathrm{E}+02$ & 658 & & & \\
\hline $3.471 \mathrm{E}+02$ & 659 & & & \\
\hline $3.408 \mathrm{E}+02$ & 660 & & & \\
\hline
\end{tabular}




\begin{tabular}{|c|c|c|c|c|}
\hline $\begin{array}{c}\text { Upper neutron } \\
\text { energy }(\mathrm{eV})\end{array}$ & $\begin{array}{c}\text { 999-group } \\
\text { structure }\end{array}$ & $\begin{array}{c}\text { SCALE } \\
\text { 238-group } \\
\text { structure }\end{array}$ & $81 \mathrm{~A}$ groups & 81B3,C groups \\
\hline $3.345 \mathrm{E}+02$ & 661 & \multirow{9}{*}{ ser uाtuा } & & \\
\hline $3.284 \mathrm{E}+02$ & 662 & & & \\
\hline $3.224 \mathrm{E}+02$ & 663 & & & \\
\hline $3.165 \mathrm{E}+02$ & 664 & & & \\
\hline $3.107 \mathrm{E}+02$ & 665 & & & \\
\hline $3.050 \mathrm{E}+02$ & 666 & & & \\
\hline $2.999 \mathrm{E}+02$ & 667 & & & \\
\hline $2.948 \mathrm{E}+02$ & 668 & & & \\
\hline $2.899 \mathrm{E}+02$ & 669 & & & \\
\hline $2.850 \mathrm{E}+02$ & 670 & \multirow{10}{*}{76} & & \\
\hline $2.801 \mathrm{E}+02$ & 671 & & \multirow[t]{10}{*}{24} & \\
\hline $2.754 \mathrm{E}+02$ & 672 & & & \\
\hline $2.707 \mathrm{E}+02$ & 673 & & & \\
\hline $2.661 \mathrm{E}+02$ & 674 & & & \\
\hline $2.615 \mathrm{E}+02$ & 675 & & & \\
\hline $2.571 \mathrm{E}+02$ & 676 & & & \\
\hline $2.527 \mathrm{E}+02$ & 677 & & & \\
\hline $2.484 \mathrm{E}+02$ & 678 & & & \\
\hline $2.442 \mathrm{E}+02$ & 679 & & & \\
\hline $2.400 \mathrm{E}+02$ & 680 & \multirow[t]{10}{*}{77} & & 24 \\
\hline $2.367 \mathrm{E}+02$ & 681 & & \multirow[t]{10}{*}{25} & \\
\hline $2.333 \mathrm{E}+02$ & 682 & & & \\
\hline $2.301 \mathrm{E}+02$ & 683 & & & \\
\hline $2.269 \mathrm{E}+02$ & 684 & & & \\
\hline $2.237 \mathrm{E}+02$ & 685 & & & \\
\hline $2.206 \mathrm{E}+02$ & 686 & & & \\
\hline $2.175 \mathrm{E}+02$ & 687 & & & \\
\hline $2.145 \mathrm{E}+02$ & 688 & & & \\
\hline $2.122 \mathrm{E}+02$ & 689 & & & \\
\hline $2.100 \mathrm{E}+02$ & 690 & \multirow[t]{2}{*}{78} & & 25 \\
\hline $2.088 \mathrm{E}+02$ & 691 & & \multirow[t]{2}{*}{26} & \\
\hline $2.075 \mathrm{E}+02$ & 692 & \multirow[t]{4}{*}{79} & & 26 \\
\hline $2.036 \mathrm{E}+02$ & 693 & & \multirow[t]{2}{*}{27} & \\
\hline $1.999 \mathrm{E}+02$ & 694 & & & \\
\hline $1.962 \mathrm{E}+02$ & 695 & & \multirow[t]{17}{*}{28} & \\
\hline $1.925 \mathrm{E}+02$ & 696 & \multirow[t]{2}{*}{80} & & 27 \\
\hline $1.892 \mathrm{E}+02$ & 697 & & & \\
\hline $1.860 \mathrm{E}+02$ & 698 & \multirow[t]{14}{*}{81} & & \multirow[t]{14}{*}{28} \\
\hline $1.835 \mathrm{E}+02$ & 699 & & & \\
\hline $1.811 \mathrm{E}+02$ & 700 & & & \\
\hline $1.786 \mathrm{E}+02$ & 701 & & & \\
\hline $1.763 \mathrm{E}+02$ & 702 & & & \\
\hline $1.739 \mathrm{E}+02$ & 703 & & & \\
\hline $1.716 \mathrm{E}+02$ & 704 & & & \\
\hline $1.693 \mathrm{E}+02$ & 705 & & & \\
\hline $1.670 \mathrm{E}+02$ & 706 & & & \\
\hline $1.650 \mathrm{E}+02$ & 707 & & & \\
\hline $1.625 \mathrm{E}+02$ & 708 & & & \\
\hline $1.600 \mathrm{E}+02$ & 709 & & & \\
\hline $1.575 \mathrm{E}+02$ & 710 & & & \\
\hline $1.550 \mathrm{E}+02$ & 711 & & & \\
\hline
\end{tabular}




\begin{tabular}{|c|c|c|c|c|}
\hline $\begin{array}{c}\text { Upper neutron } \\
\text { energy }(\mathrm{eV})\end{array}$ & $\begin{array}{c}\text { 999-group } \\
\text { structure }\end{array}$ & $\begin{array}{c}\text { SCALE } \\
\text { 238-group } \\
\text { structure }\end{array}$ & $81 \mathrm{~A}$ groups & $81 \mathrm{~B} 3, \mathrm{C}$ groups \\
\hline $1.525 \mathrm{E}+02$ & 712 & & & \\
\hline $1.500 \mathrm{E}+02$ & 713 & & & \\
\hline $1.475 \mathrm{E}+02$ & 714 & & & \\
\hline $1.450 \mathrm{E}+02$ & 715 & & & \\
\hline $1.425 \mathrm{E}+02$ & 716 & & & \\
\hline $1.400 \mathrm{E}+02$ & 717 & & & \\
\hline $1.375 \mathrm{E}+02$ & 718 & & & \\
\hline $1.350 \mathrm{E}+02$ & 719 & & & \\
\hline $1.325 \mathrm{E}+02$ & 720 & & & \\
\hline $1.301 \mathrm{E}+02$ & 721 & & & \\
\hline $1.280 \mathrm{E}+02$ & 722 & & & \\
\hline $1.260 \mathrm{E}+02$ & 723 & & & \\
\hline $1.240 \mathrm{E}+02$ & 724 & & & \\
\hline $1.220 \mathrm{E}+02$ & 725 & \multirow[t]{2}{*}{82} & & \\
\hline $1.205 \mathrm{E}+02$ & 726 & & \multirow[t]{2}{*}{29} & \\
\hline $1.190 \mathrm{E}+02$ & 727 & \multirow{2}{*}{83} & & \multirow[t]{2}{*}{29} \\
\hline $1.170 \mathrm{E}+02$ & 728 & & \multirow[t]{5}{*}{30} & \\
\hline $1.150 \mathrm{E}+02$ & 729 & \multirow[t]{3}{*}{84} & & \multirow[t]{7}{*}{30} \\
\hline $1.130 \mathrm{E}+02$ & 730 & & & \\
\hline $1.105 \mathrm{E}+02$ & 731 & & & \\
\hline $1.080 \mathrm{E}+02$ & 732 & \multirow[t]{4}{*}{85} & & \\
\hline $1.063 \mathrm{E}+02$ & 733 & & \multirow[t]{8}{*}{31} & \\
\hline $1.038 \mathrm{E}+02$ & 734 & & & \\
\hline $1.013 \mathrm{E}+02$ & 735 & & & \\
\hline $1.000 \mathrm{E}+02$ & 736 & \multirow[t]{4}{*}{86} & & \multirow[t]{8}{*}{31} \\
\hline $9.750 \mathrm{E}+01$ & 737 & & & \\
\hline $9.500 \mathrm{E}+01$ & 738 & & & \\
\hline $9.250 \mathrm{E}+01$ & 739 & & & \\
\hline $9.000 \mathrm{E}+01$ & 740 & \multirow[t]{4}{*}{87} & & \\
\hline $8.800 \mathrm{E}+01$ & 741 & & \multirow[t]{4}{*}{32} & \\
\hline $8.600 \mathrm{E}+01$ & 742 & & & \\
\hline $8.400 \mathrm{E}+01$ & 743 & & & \\
\hline $8.200 \mathrm{E}+01$ & 744 & \multirow[t]{2}{*}{88} & & \multirow[t]{2}{*}{32} \\
\hline $8.100 \mathrm{E}+01$ & 745 & & \multirow[t]{8}{*}{33} & \\
\hline $8.000 \mathrm{E}+01$ & 746 & \multirow[t]{4}{*}{89} & & \multirow[t]{8}{*}{33} \\
\hline $7.945 \mathrm{E}+01$ & 747 & & & \\
\hline $7.889 \mathrm{E}+01$ & 748 & & & \\
\hline $7.745 \mathrm{E}+01$ & 749 & & & \\
\hline $7.600 \mathrm{E}+01$ & 750 & \multirow[t]{2}{*}{90} & & \\
\hline $7.400 \mathrm{E}+01$ & 751 & & & \\
\hline $7.200 \mathrm{E}+01$ & 752 & \multirow[t]{2}{*}{91} & & \\
\hline $6.975 \mathrm{E}+01$ & 753 & & \multirow[t]{2}{*}{34} & \\
\hline $6.750 \mathrm{E}+01$ & 754 & 92 & & 34 \\
\hline $6.625 \mathrm{E}+01$ & 755 & & 35 & \\
\hline $6.500 \mathrm{E}+01$ & 756 & 93 & 36 & 35 \\
\hline $6.322 \mathrm{E}+01$ & 757 & & & \\
\hline $6.144 \mathrm{E}+01$ & 758 & & 37 & \\
\hline $6.122 \mathrm{E}+01$ & 759 & & & \\
\hline $6.100 \mathrm{E}+01$ & 760 & 94 & & 36 \\
\hline $6.000 \mathrm{E}+01$ & 761 & & & \\
\hline $5.900 \mathrm{E}+01$ & 762 & 95 & & 37 \\
\hline
\end{tabular}




\begin{tabular}{|c|c|c|c|c|}
\hline $\begin{array}{c}\text { Upper neutron } \\
\text { energy }(e V)\end{array}$ & $\begin{array}{l}\text { 999-group } \\
\text { structure }\end{array}$ & $\begin{array}{c}\text { SCALE } \\
\text { 238-group } \\
\text { structure }\end{array}$ & $81 \mathrm{~A}$ groups & 81 B3,C groups \\
\hline $5.620 \mathrm{E}+01$ & 763 & & & \\
\hline $5.340 \mathrm{E}+01$ & 764 & \multirow[t]{2}{*}{96} & & \\
\hline $5.270 \mathrm{E}+01$ & 765 & & & \\
\hline $5.200 \mathrm{E}+01$ & 766 & \multirow[t]{2}{*}{97} & & \\
\hline $5.130 \mathrm{E}+01$ & 767 & & & \\
\hline $5.060 \mathrm{E}+01$ & 768 & \multirow[t]{2}{*}{98} & & \\
\hline $4.990 \mathrm{E}+01$ & 769 & & & \\
\hline $4.920 \mathrm{E}+01$ & 770 & \multirow[t]{2}{*}{99} & & \\
\hline $4.875 \mathrm{E}+01$ & 771 & & & \\
\hline $4.830 \mathrm{E}+01$ & 772 & \multirow[t]{4}{*}{100} & & \\
\hline $4.808 \mathrm{E}+01$ & 773 & & & \\
\hline $4.785 \mathrm{E}+01$ & 774 & & & \\
\hline $4.743 \mathrm{E}+01$ & 775 & & & \\
\hline $4.700 \mathrm{E}+01$ & 776 & \multirow[t]{2}{*}{101} & & \\
\hline $4.610 \mathrm{E}+01$ & 777 & & & \\
\hline $4.520 \mathrm{E}+01$ & 778 & \multirow[t]{2}{*}{102} & & \\
\hline $4.460 \mathrm{E}+01$ & 779 & & & \\
\hline $4.400 \mathrm{E}+01$ & 780 & \multirow[t]{2}{*}{103} & & \\
\hline $4.320 \mathrm{E}+01$ & 781 & & & \\
\hline $4.240 \mathrm{E}+01$ & 782 & \multirow[t]{2}{*}{104} & & \\
\hline $4.170 \mathrm{E}+01$ & 783 & & \multirow[t]{2}{*}{38} & \\
\hline $4.100 \mathrm{E}+01$ & 784 & \multirow[t]{2}{*}{105} & & \multirow[t]{2}{*}{38} \\
\hline $4.030 \mathrm{E}+01$ & 785 & & \multirow[t]{2}{*}{39} & \\
\hline $3.960 \mathrm{E}+01$ & 786 & \multirow[t]{2}{*}{106} & & \multirow[t]{2}{*}{39} \\
\hline $3.935 \mathrm{E}+01$ & 787 & & \multirow[t]{2}{*}{40} & \\
\hline $3.910 \mathrm{E}+01$ & 788 & \multirow[t]{2}{*}{107} & & \multirow[t]{2}{*}{40} \\
\hline $3.855 \mathrm{E}+01$ & 789 & & 41 & \\
\hline $3.800 \mathrm{E}+01$ & 790 & \multirow[t]{4}{*}{108} & & \multirow[t]{4}{*}{41} \\
\hline $3.763 \mathrm{E}+01$ & 791 & & 42 & \\
\hline $3.727 \mathrm{E}+01$ & 792 & & & \\
\hline $3.713 \mathrm{E}+01$ & 793 & & & \\
\hline $3.700 \mathrm{E}+01$ & 794 & \multirow[t]{2}{*}{109} & & 42 \\
\hline $3.625 \mathrm{E}+01$ & 795 & & 43 & \\
\hline $3.550 \mathrm{E}+01$ & 796 & 110 & & 43 \\
\hline $3.505 \mathrm{E}+01$ & 797 & & & \\
\hline $3.460 \mathrm{E}+01$ & 798 & 111 & & \\
\hline $3.418 \mathrm{E}+01$ & 799 & & & \\
\hline $3.375 \mathrm{E}+01$ & 800 & 112 & & \\
\hline $3.350 \mathrm{E}+01$ & 801 & & & \\
\hline $3.325 \mathrm{E}+01$ & 802 & 113 & & \\
\hline $3.250 \mathrm{E}+01$ & 803 & & & \\
\hline $3.175 \mathrm{E}+01$ & 804 & 114 & & 44 \\
\hline $3.150 \mathrm{E}+01$ & 805 & & & \\
\hline $3.125 \mathrm{E}+01$ & 806 & 115 & & \\
\hline $3.063 \mathrm{E}+01$ & 807 & & 44 & \\
\hline $3.000 \mathrm{E}+01$ & 808 & 116 & & \\
\hline $2.951 \mathrm{E}+01$ & 809 & & & \\
\hline $2.902 \mathrm{E}+01$ & 810 & & & \\
\hline $2.826 \mathrm{E}+01$ & 811 & & & \\
\hline $2.750 \mathrm{E}+01$ & 812 & 117 & & \\
\hline $2.625 \mathrm{E}+01$ & 813 & & & \\
\hline
\end{tabular}




\begin{tabular}{|c|c|c|c|c|}
\hline $\begin{array}{c}\text { Upper neutron } \\
\text { energy }(e V)\end{array}$ & $\begin{array}{c}\text { 999-group } \\
\text { structure }\end{array}$ & $\begin{array}{c}\text { SCALE } \\
\text { 238-group } \\
\text { structure }\end{array}$ & $81 \mathrm{~A}$ groups & 81 B3,C groups \\
\hline $2.500 \mathrm{E}+01$ & 814 & \multirow[t]{2}{*}{118} & & \\
\hline $2.375 \mathrm{E}+01$ & 815 & & & \\
\hline $2.250 \mathrm{E}+01$ & 816 & \multirow[t]{2}{*}{119} & & \\
\hline $2.175 \mathrm{E}+01$ & 817 & & \multirow[t]{2}{*}{45} & \\
\hline $2.100 \mathrm{E}+01$ & 818 & \multirow[t]{2}{*}{120} & & \multirow[t]{2}{*}{45} \\
\hline $2.050 \mathrm{E}+01$ & 819 & & \multirow[t]{2}{*}{46} & \\
\hline $2.000 \mathrm{E}+01$ & 820 & \multirow[t]{2}{*}{121} & & \multirow[t]{4}{*}{46} \\
\hline $1.950 \mathrm{E}+01$ & 821 & & \multirow[t]{16}{*}{47} & \\
\hline $1.900 \mathrm{E}+01$ & 822 & \multirow[t]{2}{*}{122} & & \\
\hline $1.875 \mathrm{E}+01$ & 823 & & & \\
\hline $1.850 \mathrm{E}+01$ & 824 & \multirow{4}{*}{123} & & \multirow[t]{14}{*}{47} \\
\hline $1.805 \mathrm{E}+01$ & 825 & & & \\
\hline $1.760 \mathrm{E}+01$ & 826 & & & \\
\hline $1.730 \mathrm{E}+01$ & 827 & & & \\
\hline $1.700 \mathrm{E}+01$ & 828 & \multirow[t]{2}{*}{124} & & \\
\hline $1.650 \mathrm{E}+01$ & 829 & & & \\
\hline $1.600 \mathrm{E}+01$ & 830 & \multirow[t]{2}{*}{125} & & \\
\hline $1.555 \mathrm{E}+01$ & 831 & & & \\
\hline $1.510 \mathrm{E}+01$ & 832 & \multirow[t]{2}{*}{126} & & \\
\hline $1.475 \mathrm{E}+01$ & 833 & & & \\
\hline $1.440 \mathrm{E}+01$ & 834 & \multirow[t]{2}{*}{127} & & \\
\hline $1.408 \mathrm{E}+01$ & 835 & & & \\
\hline $1.375 \mathrm{E}+01$ & 836 & \multirow[t]{2}{*}{128} & & \\
\hline $1.333 \mathrm{E}+01$ & 837 & & \multirow[t]{6}{*}{48} & \\
\hline $1.290 \mathrm{E}+01$ & 838 & \multirow[t]{2}{*}{129} & & \multirow[t]{8}{*}{48} \\
\hline $1.240 \mathrm{E}+01$ & 839 & & & \\
\hline $1.190 \mathrm{E}+01$ & 840 & \multirow[t]{2}{*}{130} & & \\
\hline $1.170 \mathrm{E}+01$ & 841 & & & \\
\hline $1.150 \mathrm{E}+01$ & 842 & 131 & & \\
\hline $1.109 \mathrm{E}+01$ & 843 & & 49 & \\
\hline $1.068 \mathrm{E}+01$ & 844 & & & \\
\hline $1.034 \mathrm{E}+01$ & 845 & & & \\
\hline $1.000 \mathrm{E}+01$ & 846 & 132 & & 49 \\
\hline $9.550 \mathrm{E}+00$ & 847 & & & \\
\hline $9.100 \mathrm{E}+00$ & 848 & 133 & & \\
\hline $8.708 \mathrm{E}+00$ & 849 & & & \\
\hline $8.315 \mathrm{E}+00$ & 850 & & & \\
\hline $8.208 \mathrm{E}+00$ & 851 & & & \\
\hline $8.100 \mathrm{E}+00$ & 852 & 134 & & \\
\hline $7.625 \mathrm{E}+00$ & 853 & & & \\
\hline $7.150 \mathrm{E}+00$ & 854 & 135 & & \\
\hline $7.075 \mathrm{E}+00$ & 855 & & 50 & \\
\hline $7.000 \mathrm{E}+00$ & 856 & 136 & & 50 \\
\hline $6.875 \mathrm{E}+00$ & 857 & & 51 & \\
\hline $6.750 \mathrm{E}+00$ & 858 & 137 & & 51 \\
\hline $6.625 \mathrm{E}+00$ & 859 & & 52 & \\
\hline $6.500 \mathrm{E}+00$ & 860 & 138 & & 52 \\
\hline $6.375 \mathrm{E}+00$ & 861 & & 53 & \\
\hline $6.250 \mathrm{E}+00$ & 862 & 139 & & 53 \\
\hline $6.000 \mathrm{E}+00$ & 863 & 140 & & \\
\hline $5.850 \mathrm{E}+00$ & 864 & & & \\
\hline
\end{tabular}




\begin{tabular}{|c|c|c|c|c|}
\hline $\begin{array}{l}\text { Upper neutron } \\
\text { energy }(\mathrm{eV})\end{array}$ & $\begin{array}{c}\text { 999-group } \\
\text { structure }\end{array}$ & $\begin{array}{c}\text { SCALE } \\
\text { 238-group } \\
\text { structure }\end{array}$ & $81 \mathrm{~A}$ groups & 81 B3,C groups \\
\hline $5.700 \mathrm{E}+00$ & 865 & \multirow{5}{*}{141} & & \\
\hline $5.550 \mathrm{E}+00$ & 866 & & & \\
\hline $5.400 \mathrm{E}+00$ & 867 & & & \\
\hline $5.250 \mathrm{E}+00$ & 868 & & & \\
\hline $5.044 \mathrm{E}+00$ & 869 & & & \\
\hline $5.000 \mathrm{E}+00$ & 870 & \multirow[t]{2}{*}{142} & & \multirow[t]{14}{*}{54} \\
\hline $4.875 \mathrm{E}+00$ & 871 & & \multirow{14}{*}{54} & \\
\hline $4.750 \mathrm{E}+00$ & 872 & \multirow[t]{4}{*}{143} & & \\
\hline $4.500 \mathrm{E}+00$ & 873 & & & \\
\hline $4.300 \mathrm{E}+00$ & 874 & & & \\
\hline $4.150 \mathrm{E}+00$ & 875 & & & \\
\hline $4.000 \mathrm{E}+00$ & 876 & \multirow[t]{3}{*}{144} & & \\
\hline $3.928 \mathrm{E}+00$ & 877 & & & \\
\hline $3.830 \mathrm{E}+00$ & 878 & & & \\
\hline $3.730 \mathrm{E}+00$ & 879 & \multirow[t]{2}{*}{145} & & \\
\hline $3.620 \mathrm{E}+00$ & 880 & & & \\
\hline $3.500 \mathrm{E}+00$ & 881 & \multirow[t]{2}{*}{146} & & \\
\hline $3.300 \mathrm{E}+00$ & 882 & & & \\
\hline $3.150 \mathrm{E}+00$ & 883 & 147 & & \\
\hline $3.050 \mathrm{E}+00$ & 884 & 148 & & \multirow[t]{2}{*}{55} \\
\hline $3.000 \mathrm{E}+00$ & 885 & 149 & 55 & \\
\hline $2.970 \mathrm{E}+00$ & 886 & \multirow[t]{2}{*}{150} & 56 & \multirow[t]{2}{*}{56} \\
\hline $2.920 \mathrm{E}+00$ & 887 & & \multirow[t]{14}{*}{57} & \\
\hline $2.870 \mathrm{E}+00$ & 888 & \multirow[t]{2}{*}{151} & & \multirow[t]{14}{*}{57} \\
\hline $2.820 \mathrm{E}+00$ & 889 & & & \\
\hline $2.770 \mathrm{E}+00$ & 890 & \multirow[t]{2}{*}{152} & & \\
\hline $2.720 \mathrm{E}+00$ & 891 & & & \\
\hline $2.670 \mathrm{E}+00$ & 892 & \multirow[t]{2}{*}{153} & & \\
\hline $2.620 \mathrm{E}+00$ & 893 & & & \\
\hline $2.570 \mathrm{E}+00$ & 894 & \multirow[t]{2}{*}{154} & & \\
\hline $2.520 \mathrm{E}+00$ & 895 & & & \\
\hline $2.470 \mathrm{E}+00$ & 896 & \multirow[t]{2}{*}{155} & & \\
\hline $2.425 \mathrm{E}+00$ & 897 & & & \\
\hline $2.380 \mathrm{E}+00$ & 898 & \multirow[t]{2}{*}{156} & & \\
\hline $2.340 \mathrm{E}+00$ & 899 & & & \\
\hline $2.300 \mathrm{E}+00$ & 900 & \multirow[t]{2}{*}{157} & & \\
\hline $2.255 \mathrm{E}+00$ & 901 & & 58 & \\
\hline $2.210 \mathrm{E}+00$ & 902 & 158 & & 58 \\
\hline $2.165 \mathrm{E}+00$ & 903 & & & \\
\hline $2.120 \mathrm{E}+00$ & 904 & 159 & & \\
\hline $2.060 \mathrm{E}+00$ & 905 & & & \\
\hline $2.000 \mathrm{E}+00$ & 906 & 160 & & \\
\hline $1.970 \mathrm{E}+00$ & 907 & & & \\
\hline $1.940 \mathrm{E}+00$ & 908 & 161 & & \\
\hline $1.900 \mathrm{E}+00$ & 909 & & & \\
\hline $1.860 \mathrm{E}+00$ & 910 & 162 & & \\
\hline $1.815 \mathrm{E}+00$ & 911 & & & \\
\hline $1.770 \mathrm{E}+00$ & 912 & 163 & & \\
\hline $1.725 \mathrm{E}+00$ & 913 & & & \\
\hline $1.680 \mathrm{E}+00$ & 914 & 164 & & \\
\hline $1.635 \mathrm{E}+00$ & 915 & & & \\
\hline
\end{tabular}




\begin{tabular}{|c|c|c|c|c|}
\hline $\begin{array}{l}\text { Upper neutron } \\
\text { energy }(\mathrm{eV})\end{array}$ & $\begin{array}{c}\text { 999-group } \\
\text { structure }\end{array}$ & $\begin{array}{c}\text { SCALE } \\
\text { 238-group } \\
\text { structure } \\
\end{array}$ & 81A groups & 81B3,C groups \\
\hline $1.590 \mathrm{E}+00$ & 916 & \multirow[t]{2}{*}{165} & & \\
\hline $1.545 \mathrm{E}+00$ & 917 & & \multirow[t]{9}{*}{59} & \\
\hline $1.500 \mathrm{E}+00$ & 918 & 166 & & \multirow[t]{7}{*}{59} \\
\hline $1.450 \mathrm{E}+00$ & 919 & 167 & & \\
\hline $1.400 \mathrm{E}+00$ & 920 & 168 & & \\
\hline $1.350 \mathrm{E}+00$ & 921 & 169 & & \\
\hline $1.300 \mathrm{E}+00$ & 922 & 170 & & \\
\hline $1.250 \mathrm{E}+00$ & 923 & 171 & & \\
\hline $1.225 \mathrm{E}+00$ & 924 & 172 & & \\
\hline $1.200 \mathrm{E}+00$ & 925 & 173 & & \multirow[t]{5}{*}{60} \\
\hline $1.175 \mathrm{E}+00$ & 926 & 174 & \multirow[t]{5}{*}{60} & \\
\hline $1.150 \mathrm{E}+00$ & 927 & 175 & & \\
\hline $1.140 \mathrm{E}+00$ & 928 & 176 & & \\
\hline $1.130 \mathrm{E}+00$ & 929 & 177 & & \\
\hline $1.120 \mathrm{E}+00$ & 930 & 178 & & \multirow[t]{13}{*}{61} \\
\hline $1.110 \mathrm{E}+00$ & 931 & 179 & \multirow[t]{12}{*}{61} & \\
\hline $1.100 \mathrm{E}+00$ & 932 & 180 & & \\
\hline $1.090 \mathrm{E}+00$ & 933 & 181 & & \\
\hline $1.080 \mathrm{E}+00$ & 934 & 182 & & \\
\hline $1.070 \mathrm{E}+00$ & 935 & 183 & & \\
\hline $1.060 \mathrm{E}+00$ & 936 & 184 & & \\
\hline $1.050 \mathrm{E}+00$ & 937 & 185 & & \\
\hline $1.040 \mathrm{E}+00$ & 938 & 186 & & \\
\hline $1.030 \mathrm{E}+00$ & 939 & 187 & & \\
\hline $1.020 \mathrm{E}+00$ & 940 & 188 & & \\
\hline $1.010 \mathrm{E}+00$ & 941 & 189 & & \\
\hline $1.000 \mathrm{E}+00$ & 942 & 190 & & \\
\hline $9.750 \mathrm{E}-01$ & 943 & 191 & \multirow[t]{11}{*}{62} & \multirow[t]{11}{*}{62} \\
\hline $9.500 \mathrm{E}-01$ & 944 & 192 & & \\
\hline $9.250 \mathrm{E}-01$ & 945 & 193 & & \\
\hline $9.000 \mathrm{E}-01$ & 946 & 194 & & \\
\hline 8.764E-01 & 947 & & & \\
\hline $8.500 \mathrm{E}-01$ & 948 & 195 & & \\
\hline $8.000 \mathrm{E}-01$ & 949 & 196 & & \\
\hline $7.500 \mathrm{E}-01$ & 950 & 197 & & \\
\hline $7.000 \mathrm{E}-01$ & 951 & \multirow[t]{2}{*}{198} & & \\
\hline $6.826 \mathrm{E}-01$ & 952 & & & \\
\hline $6.500 \mathrm{E}-01$ & 953 & 199 & & \\
\hline $6.250 \mathrm{E}-01$ & 954 & 200 & \multirow[t]{6}{*}{63} & \multirow[t]{7}{*}{63} \\
\hline $6.000 \mathrm{E}-01$ & 955 & 201 & & \\
\hline $5.500 \mathrm{E}-01$ & 956 & \multirow[t]{2}{*}{202} & & \\
\hline $5.316 \mathrm{E}-01$ & 957 & & & \\
\hline $5.000 \mathrm{E}-01$ & 958 & 203 & & \\
\hline $4.500 \mathrm{E}-01$ & 959 & \multirow[t]{2}{*}{204} & & \\
\hline $4.140 \mathrm{E}-01$ & 960 & & \multirow[t]{2}{*}{64} & \\
\hline $4.000 \mathrm{E}-01$ & 961 & 205 & & 64 \\
\hline $3.750 \mathrm{E}-01$ & 962 & \multirow[t]{2}{*}{206} & 65 & \multirow[t]{2}{*}{65} \\
\hline $3.668 \mathrm{E}-01$ & 963 & & \multirow[t]{2}{*}{66} & \\
\hline $3.500 \mathrm{E}-01$ & 964 & 207 & & 66 \\
\hline $3.250 \mathrm{E}-01$ & 965 & 208 & 67 & \multirow[t]{2}{*}{67} \\
\hline $3.000 \mathrm{E}-01$ & 966 & 209 & & \\
\hline
\end{tabular}




\begin{tabular}{|c|c|c|c|c|}
\hline $\begin{array}{c}\text { Upper neutron } \\
\text { energy }(\mathrm{eV})\end{array}$ & $\begin{array}{c}\text { 999-group } \\
\text { structure }\end{array}$ & $\begin{array}{c}\text { SCALE } \\
\text { 238-group } \\
\text { structure }\end{array}$ & $81 \mathrm{~A}$ groups & 81B3,C groups \\
\hline $2.750 \mathrm{E}-01$ & 967 & 210 & 68 & 68 \\
\hline $2.500 \mathrm{E}-01$ & 968 & 211 & 69 & 69 \\
\hline $2.250 \mathrm{E}-01$ & 969 & 212 & 70 & 70 \\
\hline $2.000 \mathrm{E}-01$ & 970 & \multirow[t]{2}{*}{213} & \multirow[t]{3}{*}{71} & \multirow[t]{3}{*}{71} \\
\hline $1.840 \mathrm{E}-01$ & 971 & & & \\
\hline $1.750 \mathrm{E}-01$ & 972 & 214 & & \\
\hline $1.500 \mathrm{E}-01$ & 973 & 215 & \multirow[t]{2}{*}{72} & \multirow[t]{2}{*}{72} \\
\hline $1.250 \mathrm{E}-01$ & 974 & 216 & & \\
\hline $1.000 \mathrm{E}-01$ & 975 & 217 & \multirow[t]{3}{*}{73} & \multirow[t]{3}{*}{73} \\
\hline $9.000 \mathrm{E}-02$ & 976 & 218 & & \\
\hline $8.000 \mathrm{E}-02$ & 977 & 219 & & \\
\hline $7.000 \mathrm{E}-02$ & 978 & 220 & \multirow[t]{2}{*}{74} & \multirow[t]{2}{*}{74} \\
\hline $6.000 \mathrm{E}-02$ & 979 & 221 & & \\
\hline $5.000 \mathrm{E}-02$ & 980 & 222 & 75 & 75 \\
\hline $4.000 \mathrm{E}-02$ & 981 & 223 & 76 & 76 \\
\hline $3.000 \mathrm{E}-02$ & 982 & 224 & 77 & 77 \\
\hline $2.530 \mathrm{E}-02$ & 983 & \multirow[t]{4}{*}{225} & 78 & \multirow[t]{4}{*}{78} \\
\hline $2.100 \mathrm{E}-02$ & 984 & & \multirow[t]{4}{*}{79} & \\
\hline $1.850 \mathrm{E}-02$ & 985 & & & \\
\hline $1.450 \mathrm{E}-02$ & 986 & & & \\
\hline $1.000 \mathrm{E}-02$ & 987 & 226 & & 79 \\
\hline $7.500 \mathrm{E}-03$ & 988 & 227 & \multirow[t]{3}{*}{80} & \multirow[t]{3}{*}{80} \\
\hline $5.000 \mathrm{E}-03$ & 989 & 228 & & \\
\hline $4.000 \mathrm{E}-03$ & 990 & 229 & & \\
\hline $3.000 \mathrm{E}-03$ & 991 & 230 & \multirow[t]{9}{*}{81} & \multirow[t]{9}{*}{81} \\
\hline $2.500 \mathrm{E}-03$ & 992 & 231 & & \\
\hline $2.000 \mathrm{E}-03$ & 993 & 232 & & \\
\hline $1.500 \mathrm{E}-03$ & 994 & 233 & & \\
\hline $1.200 \mathrm{E}-03$ & 995 & 234 & & \\
\hline $1.000 \mathrm{E}-03$ & 996 & 235 & & \\
\hline $7.500 \mathrm{E}-04$ & 997 & 236 & & \\
\hline $5.000 \mathrm{E}-04$ & 998 & 237 & & \\
\hline $1.000 \mathrm{E}-04$ & 999 & 238 & & \\
\hline
\end{tabular}

\subsubsection{Library 81B}

Because the energy boundaries chosen for 81A did not always coincide with the energy boundaries used in SCALE's 238-group libraries, it was decided to make minor adjustments to the 81A-group structure so that it would align with the 238-group neutron energy group definitions. This alignment allows for easier comparisons between the broad-group and fine-group libraries. The $81 \mathrm{~B}$ broad-group library (Table 3.1) was generated from the SCALE 238-group V7-238 library using a weighting function based on an HTGR 238-group neutron flux solution. The HTGR model used to calculate the neutron flux solution weighting function is listed in Appendix B. The 81B energy boundaries were selected to minimize differences with the $81 \mathrm{~A}$ library energy boundaries. 


\subsubsection{Library 81B2}

The broad-group library 81B2 used the same neutron energy group structure that was used in the generation of library $81 \mathrm{~B}$, but the library was generated using SCALE/MALOCS by condensing from the 999-group fine-group library using an appropriate 999-group HTGR neutron flux solution as the weighting function. This library should better represent the HTGR solution as it is based on the much finer detail of the SCALE 999-group master library and the ultra fine neutron flux solution in 999 groups.

\subsubsection{Library 81B3}

Broad-group library 81B3 was generated directly from ENDF/B-VII nuclear data files using an HTGR weighting function (flux solution) calculated with the CENTRM module in SCALE. The SCALE input case used to calculate the CENTRM flux weighting function is listed in Appendix C. The same neutron energy boundary structure was used with library $81 \mathrm{~B} 3$ as with libraries $81 \mathrm{~B}$ and $81 \mathrm{~B} 2$.

Section 2.4 discusses the methodology employed in generating broad-group libraries directly from ENDF/B-VII nuclear data files. The SCALE input file listed in Appendix C was used to calculate the 1800K HTGR weighting function based on the CENTRM pointwise flux. This weighting approach is different from the method used in the generation of the generic 999-group fine-group library from the ENDF/B-VII files. The 999-group library was generated using the same weighting spectrum as all previous multigroup SCALE libraries, consisting of

1. Maxwellian spectrum (peak at $300 \mathrm{~K}$ ) from $10-5$ to $0.125 \mathrm{eV}$,

2. a $1 /$ E spectrum from $0.125 \mathrm{eV}$ to $67.4 \mathrm{keV}$,

3. a fission spectrum (effective temperature at $1.273 \mathrm{MeV}$ ) from $67.4 \mathrm{keV}$ to $10 \mathrm{MeV}$, and

4. a $1 / \mathrm{E}$ spectrum from 10 to $20 \mathrm{MeV}$.

The use of a weighting function that is based on the CENTRM pointwise flux from a representative HTGR model simulation is a new technique developed at ORNL during this work. The temperature $(1800 \mathrm{~K})$ considered in the calculation of the pointwise weighting function was considered appropriate for the high-temperature operation of an HTGR. This corresponds to a representative temperature of $1527^{\circ} \mathrm{C}$, or $2780^{\circ} \mathrm{F}$.

The initial version of this library (81B3i) created from the ENDF/B-VII data was then processed and enhanced with new IR f-factors and lambda factors for ${ }^{238} \mathrm{U}$. The IR factors can be used with the new BONAMI-IR module to produce results that are generally equivalent to results with CENTRM/PMC, thus removing the need to run CENTRM/PMC for each unit cell. Thus, the IR capability can result in significant speedups in computer runtime compared with the traditional resonance self-shielding methods in SCALE.

\subsubsection{Library 81C}

The final broad-group nuclear data library, $81 \mathrm{C}$, is based on the testing and improvements to library 81B3. This library is the ultimate result and includes new f-factors for ${ }^{238} \mathrm{U}$ and other actinides (App. F) and lambda factors for all nuclides. The neutron energy group boundaries are the same as the broad-group library $81 \mathrm{~B} 3$. Broad-group library $81 \mathrm{C}$, in addition to having all the necessary IR treatment factors implemented, also uses the new nuclide identification naming convention that has been developed to remove the maximum mixture number limit of 2147 in SCALE. 


\section{COMPARISON OF RESULTS WITH THE SCALE BROAD-GROUP LIBRARIES}

Tables 4.1-4.3 summarize simplified model results with SCALE using various fine- and broad-group nuclear data libraries. The final $81 \mathrm{C}$ library is intended for use in production runs with SCALE. This broad-group library can model HTGR scenarios adequately, with similar accuracy to fine-group library runs but with considerably less computational time for resonance self-shielding of the cross sections. In the results presented in this section, BONAMI-IR and the $81 \mathrm{C}$ library ran 35 to 100 times faster than CENTRM/PMC with the same library.

Table 4.1 shows the results for a series of KENO MG cases for a homogenous HTGR pin cell model that is representative of a prismatic NGNP design. These results are compared with the 999 group library eigenvalue solution. The results obtained with the various 81-group libraries compare quite favorably with respect to the 238-group KENO result. The cases in Table 4.1 all use CENTRM cross-section processing with white boundary conditions at a temperature of $300 \mathrm{~K}$.

Table 4.1. $\mathrm{k}_{\text {eff }}$ comparisons for MG KENO homogeneous cell HTGR model

\begin{tabular}{|c|c|c|}
\hline Libraries & $\mathbf{k}_{\text {eff }}$ & $\begin{array}{c}\Delta \mathbf{k} \text { relative to 999-group } \\
\text { result } \mathbf{( p c m )}\end{array}$ \\
\hline $81 \mathrm{~A}$ & $1.25766 \pm 0.00039$ & $-300 \pm 81$ \\
\hline $81 \mathrm{~B}$ & $1.25746 \pm 0.00040$ & $-320 \pm 83$ \\
\hline $81 \mathrm{C}$ & $1.25586 \pm 0.00040$ & $-480 \pm 82$ \\
\hline 238 & $1.25769 \pm 0.00041$ & $-376 \pm 88$ \\
\hline 999 & $1.26066 \pm 0.00042$ & $\mathrm{~N} / \mathrm{A}$ \\
\hline
\end{tabular}

Table 4.2 shows results of a very simple XSDRN 1-D homogeneous HTGR core model at 300K and $1200 \mathrm{~K}$. Results using BONAMI-IR and the 81C Library are compared with cases using CENTRM with the 81C, 238-group, and 999-group libraries. Note that the CENTRM cases use a triangular pitch lattice cell that produces homogenized number densities for the 1-D XSDRN model. This simple model is not as precise as the benchmark cases that follow.

Table 4.2. $\mathrm{k}_{\mathrm{eff}}$ comparisons for homogeneous 1-D radial model

\begin{tabular}{|c|c|c|c|c|c|}
\hline $\mathbf{k}_{\text {eff }}$ & $\mathbf{T}(\mathbf{K})$ & $\mathbf{C E N T R M}$ & $\boldsymbol{\Delta}_{\text {eff }}(\mathbf{p c m})^{\mathbf{a}}$ & BONAMI-IR $^{*} \mathbf{\Delta k}_{\text {eff }}(\mathbf{p c m})^{\mathbf{a}}$ \\
\hline $81 \mathrm{C}$ & 300 & 1.25214 & -378 & 1.24397 & -1195 \\
\hline 238 & 300 & 1.25434 & -158 & N/A & N/A \\
\hline 999 & 300 & 1.25592 & - & N/A & -814 \\
\hline $81 C$ & 1200 & 1.11115 & -364 & 1.10665 & N/A \\
\hline 238 & 1200 & 1.11279 & -200 & N/A & N/A \\
\hline 999 & 1200 & 1.11479 & - & N/A & \\
\hline
\end{tabular}

${ }^{\text {a }}$ Difference from CENTRM case with 999 groups at same temperature. 
The High Temperature Engineering Test Reactor (HTTR) [12,13], which is the first HTGR in Japan, is a prismatic fuel graphite-moderated and helium-cooled reactor with a thermal output of $30 \mathrm{MW}$ and a maximum outlet gas temperature of $950^{\circ} \mathrm{C}$ and has the capability to demonstrate nuclear process heat utilization using an intermediate heat exchanger. The construction of the HTTR was decided by Japanese Atomic Energy Commission (JAEC) in 1987 and started in March 1991 by the Japan Atomic Energy Research Institute (JAERI) to establish and upgrade the technology basis for an HTGR. The HTTR was intended to serve as a potential tool for new and innovative basic research on high temperature technologies.

Calculations were performed in this work with two of the HTTR benchmark cases (case 1 and case 2) from the SCALE HTGR validation report [14]. The case 2 input file is listed in Appendix D, and both a cross-sectional and a vertical view of this HTTR model are shown in Appendix E. The calculated $\mathrm{k}_{\text {eff }}$ results, and the relative $\Delta \mathrm{k}$ values with respect to the CE KENO results are tabulated in Table 4.3 and 4.4. The results obtained with the $81 \mathrm{C}$ library and BONAMI-IR show good agreement with both the 238group library and the $\mathrm{CE}$ results.

Table 4.3. $\mathbf{k}_{\text {eff }}$ results for HTTR benchmark case 1

\begin{tabular}{|c|c|c|c|}
\hline Library & $\begin{array}{c}\text { Cross-section } \\
\text { processor }\end{array}$ & $\mathbf{k}_{\text {eff }}$ & $\begin{array}{c}\Delta \mathbf{k}_{\text {eff }}(\mathbf{p c m}) \\
\text { relative to CE }\end{array}$ \\
\hline $81 \mathrm{C}$ & BONAMI-IR & $1.21629 \pm 0.00024$ & $-305 \pm 49$ \\
\hline $81 \mathrm{C}$ & CENTRM & $1.21661 \pm 0.00022$ & $-273 \pm 47$ \\
\hline 238 & CENTRM & $1.21887 \pm 0.00025$ & $-47 \pm 50$ \\
\hline 999 & CENTRM & $1.21807 \pm 0.00023$ & $-127 \pm 48$ \\
\hline $\mathrm{CE}$ & N/A & $1.21934 \pm 0.00025$ & - \\
\hline
\end{tabular}

Table 4.4. $\mathrm{k}_{\mathrm{eff}}$ results for HTTR benchmark case 2

\begin{tabular}{|c|c|c|c|}
\hline Library & Cross-section processor & $\mathbf{k}_{\text {eff }}$ & $\mathbf{\Delta k}_{\text {eff }}$ (pcm) relative to CE \\
\hline $81 \mathrm{C}$ & BONAMI-IR & $1.20799 \pm 0.00027$ & $-374 \pm 52$ \\
\hline $81 \mathrm{C}$ & CENTRM & $1.20659 \pm 0.00029$ & $-514 \pm 54$ \\
\hline 238 & CENTRM & $1.20930 \pm 0.00023$ & $-243 \pm 48$ \\
\hline CE & N/A & $1.21173 \pm 0.00025$ & - \\
\hline
\end{tabular}

The performance of the 81C library for analyses of pebble bed reactor (PBR) configurations was assessed using two test cases: (1) a pebble unit cell with fuel representative of the HTR-10 reactor at full power and (2) the first critical core of HTR-10. The models that were used for testing are described in detail elsewhere [14]. The model for the pebble unit cell is a 1-D SCALE/XSDRN model. The model for the first critical core of HTR-10 is a full 3-D SCALE/KENO-VI model that has been developed using benchmark specifications included in the IRPhE Handbook [15]. The double heterogeneity of fuel is modeled in SCALE using the DOUBLEHET option for multigroup cross-section processing.

The results obtained with SCALE for the pebble unit cell at operating temperature (1200K for fuel and 900K for coolant) are presented in Table 4.5, as obtained using the 81C HTGR library and the standard 238-group ENDF/B-VII transport library in SCALE. The 81C library was used with both CENTRM and the new BONAMI-IR for cross section self-shielding. Also shown in Table 4.5 is the result obtained with MCNP5 continuous energy ENDF/B-VII data for the same configuration. The MCNP5 model explicitly 
represents the fuel particles inside the fuel pebbles using a lattice representation that ensures the fuel particles do not intersect the interface of the graphite matrix with the pebble shell [14]. The result obtained with the 81-group library and BONAMI-IR is within $146 \mathrm{pcm}$ of the SCALE result for the 238group library and within $271 \mathrm{pcm}$ of the MCNP result.

Table 4.5. $k_{\text {eff }}$ results for HTR-10 pebble unit cell (1200K fuel, 900K coolant)

\begin{tabular}{|c|c|c|c|c|c|}
\hline Code & Library & Cross-section processor & $\mathbf{k}_{\text {eff }}$ & $\Delta k_{\text {eff }}(p c m)^{d}$ & $\Delta \mathbf{k}_{\text {eff }}(\mathbf{p c m})^{\mathrm{e}}$ \\
\hline MCNP & $\mathrm{CE}^{\mathrm{a}}$ ENDF/B-VII & $\mathrm{NA}^{\mathrm{b}}$ & $\begin{array}{c}1.60822 \\
(\sigma=0.00021)^{c}\end{array}$ & - & -125 \\
\hline SCALE & $\begin{array}{c}\text { 238-group ENDF/B-VII } \\
81 \mathrm{C} \\
81 \mathrm{C}\end{array}$ & $\begin{array}{c}\text { CENTRM } \\
\text { CENTRM } \\
\text { BONAMI-IR }\end{array}$ & $\begin{array}{l}1.60936 \\
1.60783 \\
1.61082\end{array}$ & $\begin{array}{l}125 \\
-28 \\
-271\end{array}$ & $\begin{array}{c}- \\
-153 \\
146\end{array}$ \\
\hline
\end{tabular}

To assess the effect of the temperature on library performance, the same pebble unit cell was calculated with $300 \mathrm{~K}$ temperature in both fuel and coolant. The corresponding results are presented in Table 4.6. If the SCALE result for the 238-group library is used as the reference for comparison, the result obtained with the 81-group library is within $148 \mathrm{pcm}$ when using CENTRM and within $338 \mathrm{pcm}$ when using BONAMI-IR.

Table 4 6. $k_{\text {eff }}$ results for HTR-10 pebble unit (300K)

\begin{tabular}{|c|c|c|c|c|c|}
\hline Code & Library & $\begin{array}{c}\text { Cross-section } \\
\text { Processor } \\
\end{array}$ & $\mathbf{k}_{\text {eff }}$ & $\left.\Delta k_{\text {eff }}(p c m)\right)^{d}$ & $\left.\Delta k_{\text {eff }}(p c m)\right)^{e}$ \\
\hline MCNP & $\mathrm{CE}^{\mathrm{a}}$ ENDF/B-VII & $\mathrm{NA}^{\mathrm{b}}$ & $\begin{array}{c}1.69040 \\
(\sigma=0.00014)^{\mathrm{c}}\end{array}$ & - & 110 \\
\hline SCALE & $\begin{array}{c}\text { 238-group ENDF/B-VII } \\
81 \mathrm{C} \\
81 \mathrm{C}\end{array}$ & $\begin{array}{c}\text { CENTRM } \\
\text { CENTRM } \\
\text { BONAMI-IR }\end{array}$ & $\begin{array}{l}1.68930 \\
1.68782 \\
1.68592\end{array}$ & $\begin{array}{l}-110 \\
-258 \\
-448\end{array}$ & $\begin{array}{c}- \\
-148 \\
-338\end{array}$ \\
\hline
\end{tabular}

The results obtained for the HTR-10 first core (full core 3-D model) are shown in Table 4.7. There is an excellent agreement between MCNP and SCALE when using the 238-group ENDF/B-VII library. The result obtained with the 81-group library and BONAMI-IR is within $357 \mathrm{pcm}$ of the 238-group library result with CENTRM. This difference is consistent with the difference seen in Table 4.6 for the pebble unit cell at the same temperature $(300 \mathrm{~K})$. 
Table 4.7. $k_{\text {eff }}$ results for HTR-10 full core

\begin{tabular}{|c|c|c|c|c|c|}
\hline Code & Library & Cross-section processor & $\mathbf{k}_{\text {eff }}$ & $\Delta k_{\text {eff }}(p c m)^{d}$ & $\Delta \mathbf{k}_{\text {eff }}(\mathrm{pcm})^{\mathrm{c}}$ \\
\hline MCNP & $\mathrm{CE}^{\mathrm{a}}$ ENDF/B-VII & $\mathrm{NA}^{\mathrm{b}}$ & $\begin{array}{c}1.01473 \\
(\sigma=0.00021)^{\mathrm{c}}\end{array}$ & - & $54 \pm 85$ \\
\hline SCALE & $\begin{array}{c}\text { 238-group ENDF/B-VII } \\
81 \mathrm{C}\end{array}$ & $\begin{array}{c}\text { CENTRM } \\
\text { BONAMI-IR }\end{array}$ & $\begin{array}{c}1.01419 \\
(\sigma=0.00082) \\
1.01062 \\
(\sigma=0.00087)\end{array}$ & $\begin{array}{l}-54 \pm 85 \\
-411 \pm 89\end{array}$ & $\begin{array}{c}- \\
-357 \pm 120\end{array}$ \\
\hline
\end{tabular}

The calculated results with BONAMI-IR and the 81C library for the HTTR and HTR-10 reactor benchmarks demonstrate the capability to produce accurate results for actual operating HTGRs, both with prismatic and pebble bed fuels. These results show good agreement with CE and 238-group calculations. Although further verification and validation of BONAMI-IR and the $81 \mathrm{C}$ library are desirable, these results presented here provide confidence that this library can be useful for HTGR analyses. 


\section{SUMMARY AND RECOMMENDATIONS}

The final 81-group library allows for the modeling of HTGR cases with SCALE with sufficient accuracy and faster CPU times than the V7-238 library. Further processing to include intermediate resonance features provides an additional improvement by reducing computational times for resonance selfshielding (up to 100 times faster) without loss of accuracy.

We observed that

1. HTGR broad-group libraries need more groups than LWR broad-group libraries.

2. In HTGRs, the average neutron flux distribution in the vicinity of fuel is more important for neutronics and self-shielding considerations than the flux within the fuel.

3. Fine-group libraries with many groups (such as the new 999-group library) properly show details of the increase in flux at the lower end of resonances, due to the self-shielding of the resonance and the reduction in cross section at the lower energy.

4. The use of flux values from the average flux distribution of an HTGR model is an appropriate weighting function for use in the generation of broad-group libraries.

The effectiveness and correctness of a broad-group nuclear data library is quite sensitive to the neutron energy boundary structure and to the weighting function (usually a fine-group neutron flux solution) that is used in generating the library from $\mathrm{ENDF} / \mathrm{B}$ files or through condensation from a fine-group master library.

Based on the results presented in this report, the choice of the broad-group energy boundaries for 81C library allows SCALE to model HTGR cases with reasonable accuracy and significantly faster CPU times than fine-group or CE calculations. The new $81 \mathrm{C}$ library includes new lambda factors for all nuclides and f-factors for ${ }^{238} \mathrm{U}$ and other actinides. It also contains high-temperature data consistent with HTGR operation and modeling. The $81 \mathrm{C}$ library requires the BONAMI-IR module in SCALE to fully utilize data in the library. When the IR data are processed with BONAMI-IR, accurate results can be obtained with significantly reduced computational runtimes. 



\section{REFERENCES}

1. SCALE: A Comprehensive Modeling and Simulation Suite for Nuclear Safety Analysis and Design, ORNL/TM-2005/39, Version 6.1, Oak Ridge National Laboratory, Oak Ridge, Tennessee, June 2011. Available from Radiation Safety Information Computational Center at Oak Ridge National Laboratory as CCC-785.

2. S. M. Bowman, "SCALE 6: Comprehensive Nuclear Safety Analysis Code System," Nucl. Technol. 174(2), 126-148 (May 2011).

3. N. M. Greene, J. L. Lucius, L. M. Petrie, W. E. Ford, III, J. E. White, and R. Q. Wright, $A M P X-A$ Modular Code System to Generate Multigroup Neutron-Gamma Cross Sections from ENDF/B, ORNL/TM-3706 (AMPX-1), Union Carbide Corporation (Nuclear Division), Oak Ridge National Laboratory, 1976.

4. M. E. Dunn, N. M. Greene, "AMPX-2000: A Cross-Section Processing System for Generating Nuclear Data for Criticality Safety Applications," Trans. Am. Nucl. Soc. 86, 118 (2002).

5. MCNP-A General Monte Carlo N-Particle Transport Code, Version 5, LA-CP-03-0245, Los Alamos National Laboratory, April 2003.

6. D. Wiarda et al, "AMPX Cross-Section Processing Status", Presentations at the 2009 and the 2010 Cross Section Evaluation Working Group (CSEWG) and U.S. Nuclear Data Program (USNDP) Annual Meetings, National Nuclear Data Center, Brookhaven National Laboratory.

7. M.L. Williams, Kang-Seog Kim, and D. F. Hollenbach, Generation of Multigroup Cross Sections for the Very High Temperature Reactor, Final Report - Department of Energy Generation IV Nuclear Energy Systems Initiative Program, VHTR Advanced Modeling and Simulation Project, Oak Ridge National Laboratory, September 25, 2009.

8. Kang-Seog Kim, M. L. Williams, D. F. Hollenbach, "RIML: A Program to Generate Intermediate Resonance Parameters, Self-Shielded Cross Sections, Subgroup Levels and Weights, and Associated AMPX Master Library," Oak Ridge National Laboratory, October 2, 2009

9. "The Numerical Nuclear Reactor for High Fidelity Integrated Simulation of Neutronic, ThermalHydraulic and Thermo-Mechanical Phenomena," Final Report of US/ROK International Nuclear Energy Research Initiative Project Number 2002-010-K, Argonne National Laboratory, Korea Atomic Energy Research Institute, Purdue University, and Seoul National University, March 2005.

10. R. Goldstein and E. R. Cohen, "Theory of Resonance Absorption of Neutrons," Nucl. Sci. Eng. 13, $132(1962)$.

11. National Nuclear Data Center (NNDC) at Brookhaven National Laboratory (BNL), website http://www.nndc.bnl.gov

12. IAEA, Evaluation of High Temperature Gas Cooled Reactor Performance: Benchmark Analysis Related to Initial Testing of the HTTR and HTR-10, IAEA-TECDOC-1382, International Atomic Energy Agency, Vienna, November 2003. 
13. International Handbook of Evaluated Reactor Physics Benchmark Experiments, NEA-1765, IRPHE2009-HANDBOOK; HTTR-GCR-RESR-001, CRIT-SUB-REAC-COEF-KIN-RRATE (new), "Evaluation of the Start-Up Core Physics Tests at Japan's High Temperature Engineering Test Reactor (Fully-Loaded Core)," March 21, 2009.

14. G. Ilas, D. Ilas, R.P. Kelly, and E.E. Sunny, Validation of SCALE for High Temperature Gas-Cooled Reactor Analysis, ORNL/TM-2011/161 (2011).

15. W. K. Terry, L. M. Montierth, S. S. Kim, J. J. Cogliati, and A. M. Ougouag, "Evaluation of the Initial Critical Configuration of the HTR-10 Pebble-Bed Reactor," International Handbook of Evaluated Reactor Physics Benchmark Experiments (IRPhE) Handbook, Nuclear Energy Agency (March 2009). 
APPENDIX A

DESCRIPTION OF INTERMEDIATE RESONANCE METHOD IN SCALE 



\section{A.1 INTERMEDIATE RESONANCE APPROXIMATION}

The intermediate resonance (IR) approximation was proposed in the 1960s as an extension to the narrow resonance (NR) and wide resonance (WR) approximations, which are used in solving the slowing-down equation to obtain an analytical flux expression for computing multigroup (MG) cross sections. The NR approximation is used to represent elastic scattering sources of nuclides for which the neutron energy loss is large compared to the practical width of resonances for the absorber materials of interest. This approximation tends to be more accurate for light nuclides (e.g., moderators) and for higher energy ranges. Conversely, the WR approximation is used to represent elastic scattering sources of nuclides for which the neutron energy loss is small compared to the practical widths. This approximation tends to be more accurate for heavy nuclides (e.g., the limit of infinite mass is usually assumed) and for lower energy ranges. Since most resonance absorption in LEU thermal reactors occurs in ${ }^{238} \mathrm{U}$, this material is usually used as the basis to determine if a nuclide is a NR or a WR scatterer.

Many materials cannot be treated accurately by either the NR or WR methods. The IR method provides a more generalized approach in which the scattering source is represented by a linear combination of NR and WR expressions; i.e., for scatterers with slowing-down properties intermediate between NR and WR scatterers. This is done by introducing an IR parameter usually called lambda factors, for which NR scatters have $\lambda=1$, WR scatters have $\lambda=0$, and fractional $\lambda$ 's are for intermediate scatterers. Codes have been developed by ORNL to determine group-dependent lambda values for all materials, using the procedure described in Section A.2. Lambda values are included in the HTR 81-group library.

Applying the IR approximation and neglecting resonance overlap effects in the slowing-down equation, the following analytical expression is obtained for the flux spectrum near a resonance of nuclide " $r$ ":

$$
\Phi_{\mathrm{IR}}^{(\mathrm{r})}\left(\mathrm{E} ; \sigma_{0}^{(\mathrm{r})}\right)=\left(\frac{\sigma_{\mathrm{p}}^{(\mathrm{r})}+\sigma_{0}^{(\mathrm{r})}}{\sigma_{\mathrm{t}}^{(\mathrm{r})}(\mathrm{E})+\sigma_{0}^{(\mathrm{r})}}\right) \frac{1}{\mathrm{E}}
$$

where $\sigma_{\mathrm{t}}^{(\mathrm{r})}(\mathrm{E}), \sigma_{\mathrm{p}}^{(\mathrm{r})}, \sigma_{0}^{(\mathrm{r})}$ are the total, potential, and background cross sections for resonance material " $\mathrm{r}$ ".

The background cross section in Eq. 1 depends on the lambda factors and is equal to

$$
\sigma_{0}^{(\mathrm{r})}=\frac{1}{\mathrm{~N}^{(\mathrm{r})}} \sum_{j \neq r} \lambda^{(\mathrm{j})} \sum_{\mathrm{p}}^{(\mathrm{j})}
$$

Equation 2 is appropriate for a homogeneous medium, but a similar expression also can be used for heterogeneous lattices by including an additional constant called the escape cross section. Eq. 1 shows that the IR method allows the flux energy spectrum to be parameterized in terms of the single variable $\sigma_{0}^{(\mathrm{r})}$ , which indicates the degree of resonance self-shielding. The value of $\sigma_{0}^{(\mathrm{r})}$ can vary by multigroup, but it is not a function of energy within a group.

Energy-dependent spectra for weighting MG cross sections of an arbitrary resonance material " $r$ " are obtained by solving the slowing-down equation with the pointwise code CENTRM for a homogeneous mixture composed of " $r$ " plus hydrogen. The hydrogen concentration is varied to produce the desired background cross sections in a predetermined set that spans the expected range of self-shielding for the resonance material, so that a set of MG data are computed at varying degrees of self-shielding. These are 
converted into group-dependent self-shielding factors parameterized versus $\sigma_{0}^{(\mathrm{r})}$, which are stored on the AMPX master library.

During a reactor physics calculation with TRITON, for example, the background for the system of interest is computed using eq. 2 with problem-specific materials and concentrations, and the corresponding shielding factor is found by interpolating from the set of background cross sections on the library. This is done by the SCALE code BONAMI, which has been modified to use the IR expression for the background cross section. The self-shielded cross section for the particular system is equal to the product of the interpolated shielding factor and the unshielded (i.e., infinitely dilute) cross section, which is also stored in the master library. The BONAMI IR procedure for computing self-shielded cross sections is very fast since only data interpolation is required.

\section{A.2 COMPUTATION OF HYDROGEN-EQUIVALENT LAMBDA FACTORS}

An important component of the IR method is to have reasonable values for the IR lambda values. ORNL computes these values using the "hydrogen equivalence" approach based on ${ }^{238} \mathrm{U}$ resonances. In this wellestablished method, it is assumed that hydrogen is a true NR material $(\lambda=1)$ since a neutron can lose essentially all of its energy in single elastic collision. A table of self-shielded cross sections versus background cross sections is generated for mixtures of ${ }^{238} \mathrm{U}$ and hydrogen with varying concentrations, using CENTRM calculations as described in the previous section. To obtain lambdas for nuclides other than hydrogen, a portion of the hydrogen number density in the mixture is replaced by another nuclide " $j$ ". If a one-to-one exchange of hydrogen atoms with atoms of " $j$ " is done (i.e., number of hydrogen atoms removed equals the number of $j$ added), the shielded cross section for the mixture will be different than the corresponding mixture containing only hydrogen, since the slowing-down properties of $j$ are different. However instead of one-to-one replacement, the number of $j$ atoms is modified to obtain the same shielded cross section as obtained with hydrogen. This is called the hydrogen equivalent number density of $j$, and from this value the corresponding lambda value for nuclide $j$ can be found. The procedure is repeated for each multigroup to obtain group-dependent lambdas. The lambda factors are not very sensitive to temperature and thus have been generated only for the nominal fuel temperature of $1500 \mathrm{~K}$ in the HTR 81-group library. 


\section{APPENDIX B}

INPUT FILE FOR RADIAL CORE MODEL 999-GROUP (VHTR) MODEL 

Presented here is an input file for the radial_core_model-999grps (VHTR) model.

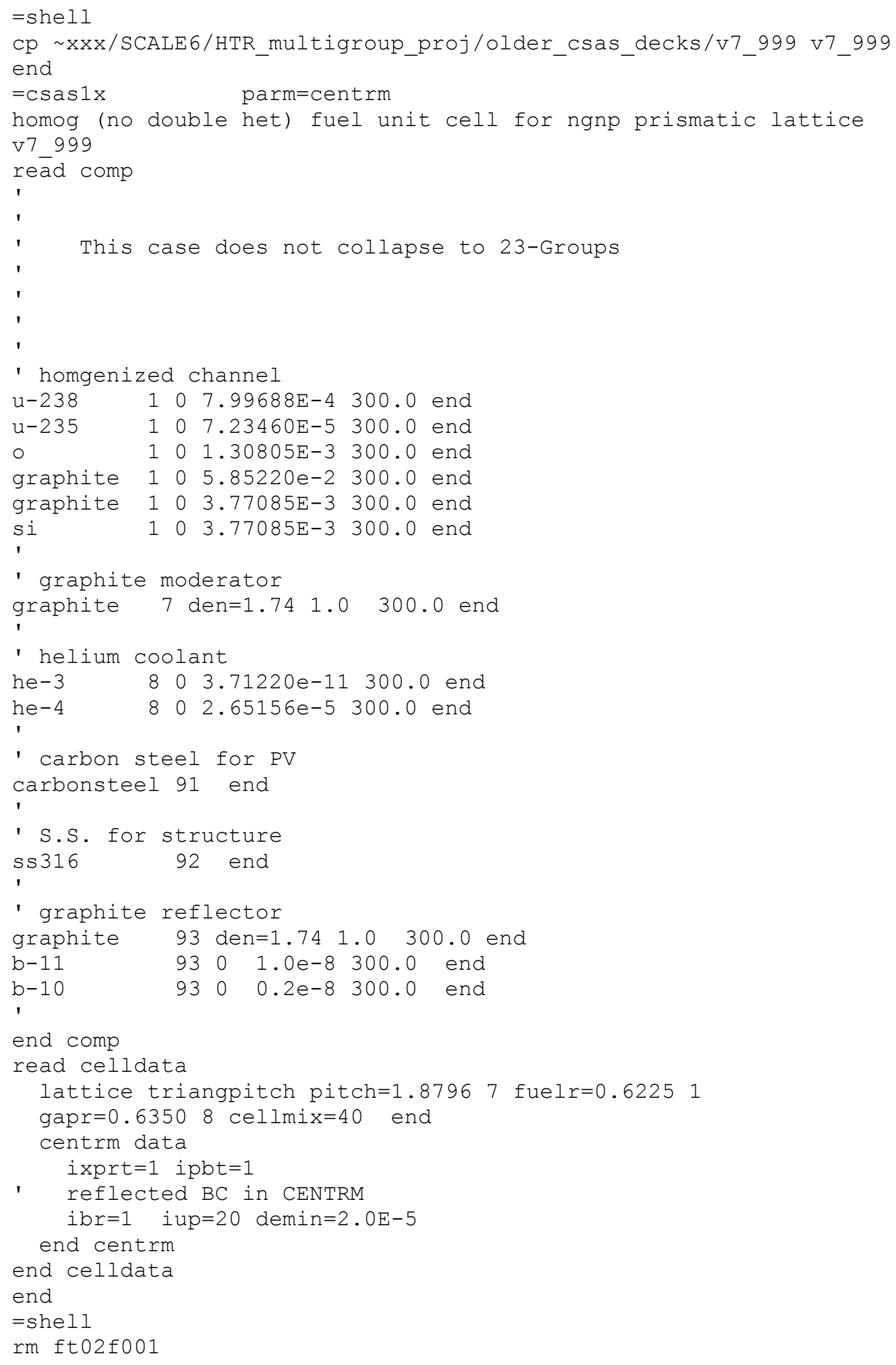




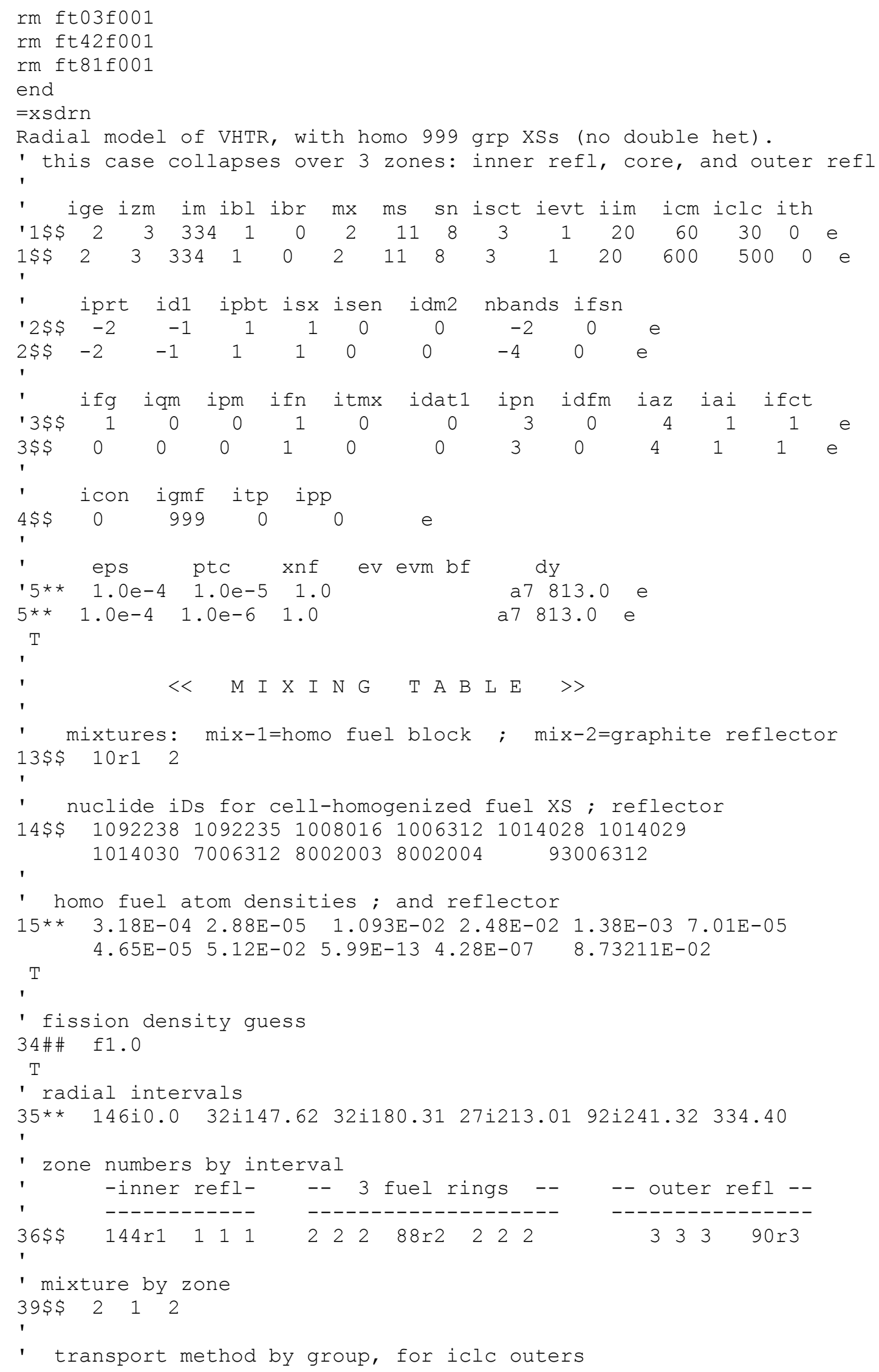









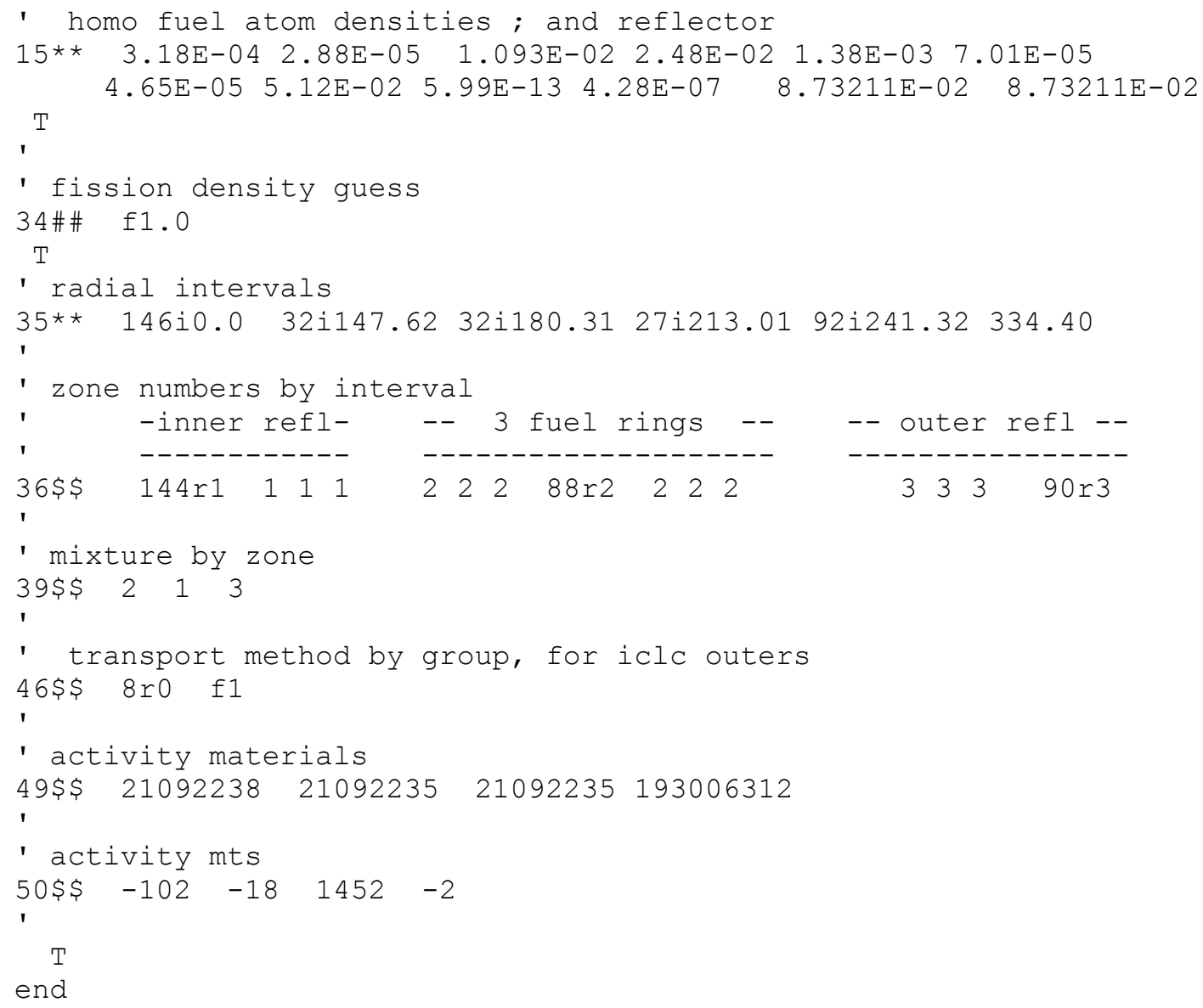




\section{APPENDIX C}

INPUT FOR GENERATING CENTRM POINTWISE FLUX WEIGHTING FUNCTIONS 

Presented here is an input file for generating a temperature-dependent CENTRM pointwise flux weighting function (this example for $1800 \mathrm{~K}$ ).

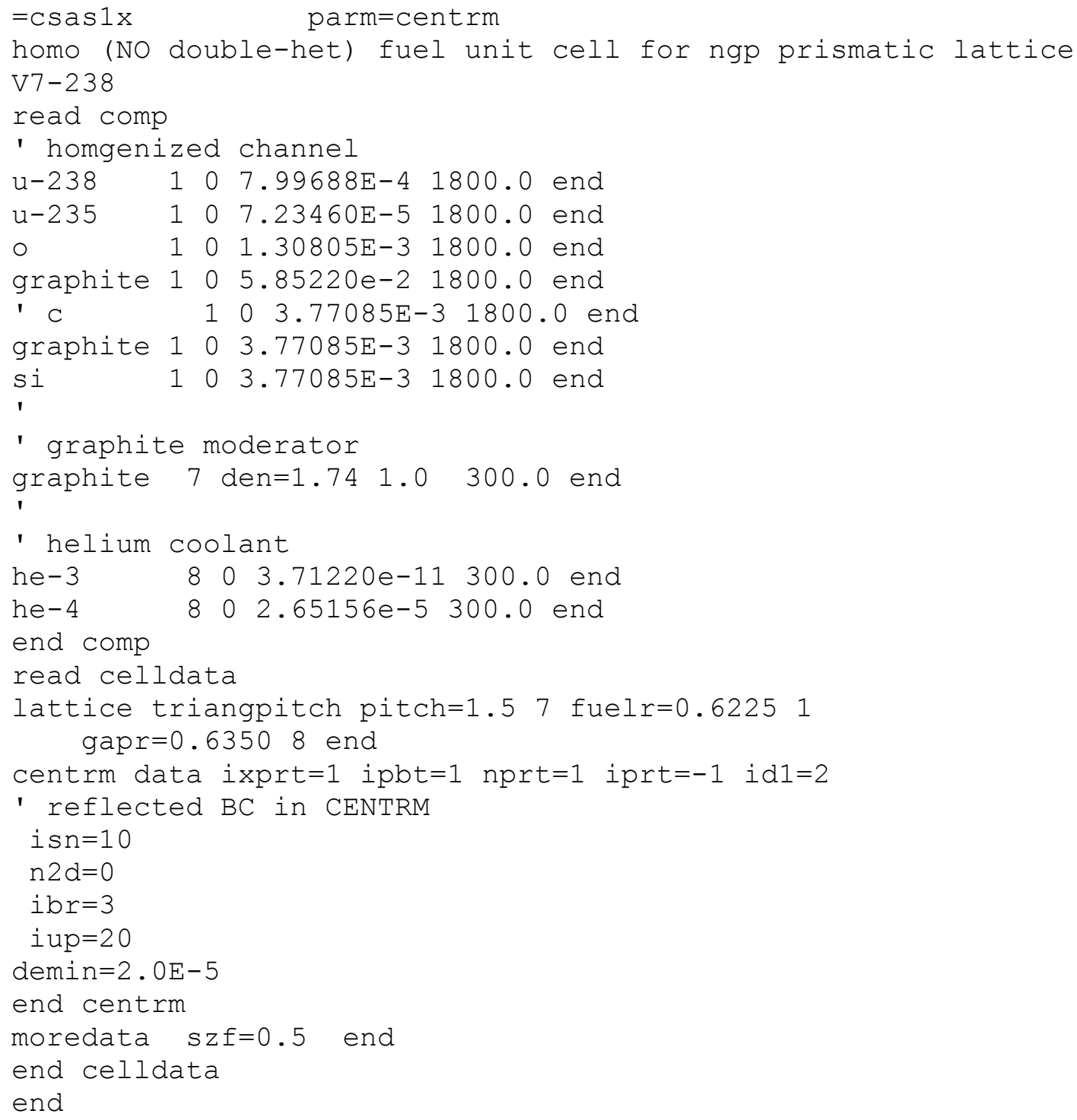





\section{APPENDIX D}

INPUT FOR TEST2R3_MG: SAMPLE JAPANESE HTTR BENCHMARK CASE 

Presented here is input for the Test2r3_Mg: sample Japanese HTTR benchmark case

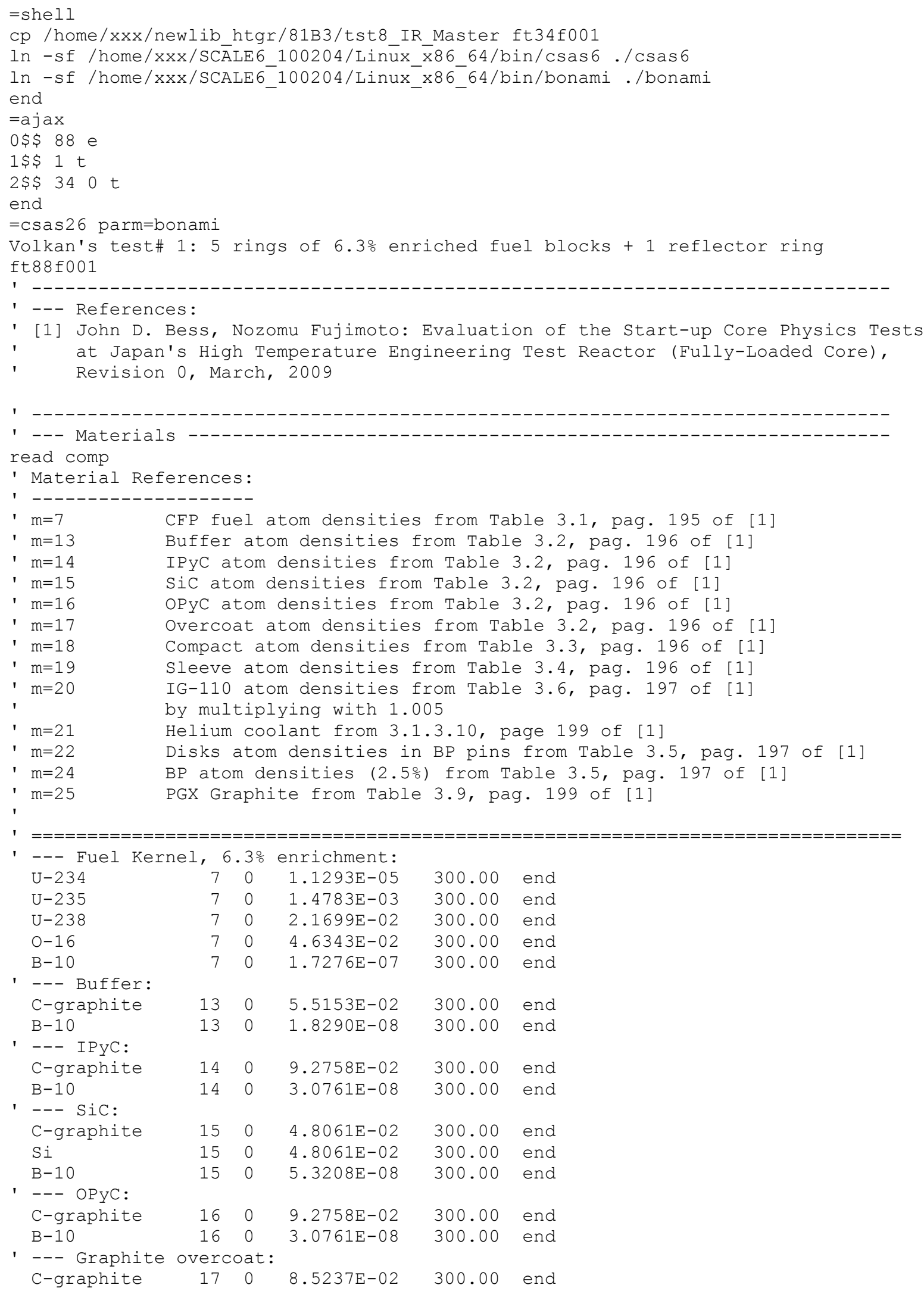




\begin{tabular}{|c|c|c|c|c|c|c|}
\hline & $B-10$ & 17 & 0 & $2.8267 E-08$ & 300.00 & end \\
\hline \multirow[t]{3}{*}{ 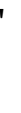 } & --- Graphite & ompa & ct: & & & \\
\hline & C-graphite & 18 & 0 & $8.5237 E-02$ & 300.00 & end \\
\hline & $B-10$ & 18 & 0 & $1.5452 \mathrm{E}-08$ & 300.00 & end \\
\hline ' & --- Graphite & leev & & & & \\
\hline & C-graphite & 19 & 0 & $8.8747 E-02$ & 300.00 & end \\
\hline & $B-10$ & 19 & 0 & $7.2596 \mathrm{E}-09$ & 300.00 & end \\
\hline ' & --- IG-110 G & phit & e: & & & \\
\hline & C-graphite & 20 & 0 & $8.8243 E-02$ & 300.00 & end \\
\hline & $B-10$ & 20 & 0 & $7.8036 \mathrm{E}-09$ & 300.00 & end \\
\hline \multirow[t]{2}{*}{ ' } & --- Helium o & lant & & & & \\
\hline & $\mathrm{He}$ & 21 & 0 & $2.4616 E-05$ & 300.00 & en \\
\hline \multirow[t]{3}{*}{ ' } & --- Graphite & isks & & & & \\
\hline & C-graphite & 22 & 0 & $8.8747 \mathrm{E}-02$ & 300.00 & end \\
\hline & $B-10$ & 22 & 0 & $7.2596 \mathrm{E}-09$ & 300.00 & end \\
\hline ' & \multicolumn{6}{|c|}{--- Burnable poison (2.5wt\%): } \\
\hline & C-graphite & 24 & 0 & $8.7995 E-02$ & 300.00 & er \\
\hline & $B-10$ & 24 & 0 & $4.9882 \mathrm{E}-04$ & 300.00 & er \\
\hline & $B-11$ & 24 & 0 & $2.0078 \mathrm{E}-03$ & 300.00 & end \\
\hline & \multicolumn{5}{|c|}{--- PGX Graphite: } & \\
\hline & C-graphite & 25 & 0 & $8.6134 \mathrm{E}-02$ & 300.00 & er \\
\hline & $B-10$ & 25 & 0 & $3.6372 \mathrm{E}-08$ & 300.00 & end \\
\hline
\end{tabular}

' --- Homogenized graphite compact (inner and outer helium embeded):

' Obtained by volumetric homogenization of materials 18 and 21

$\begin{array}{llllll}\text { He } & 28 & 0 & 4.6313 \mathrm{E}-06 & 300.00 & \text { end } \\ \text { C-graphite } & 28 & 0 & 6.8834 \mathrm{E}-02 & 300.00 & \text { end } \\ \text { B-10 } & 28 & 0 & 4.7270 \mathrm{E}-09 & 300.00 & \text { end }\end{array}$

end comp

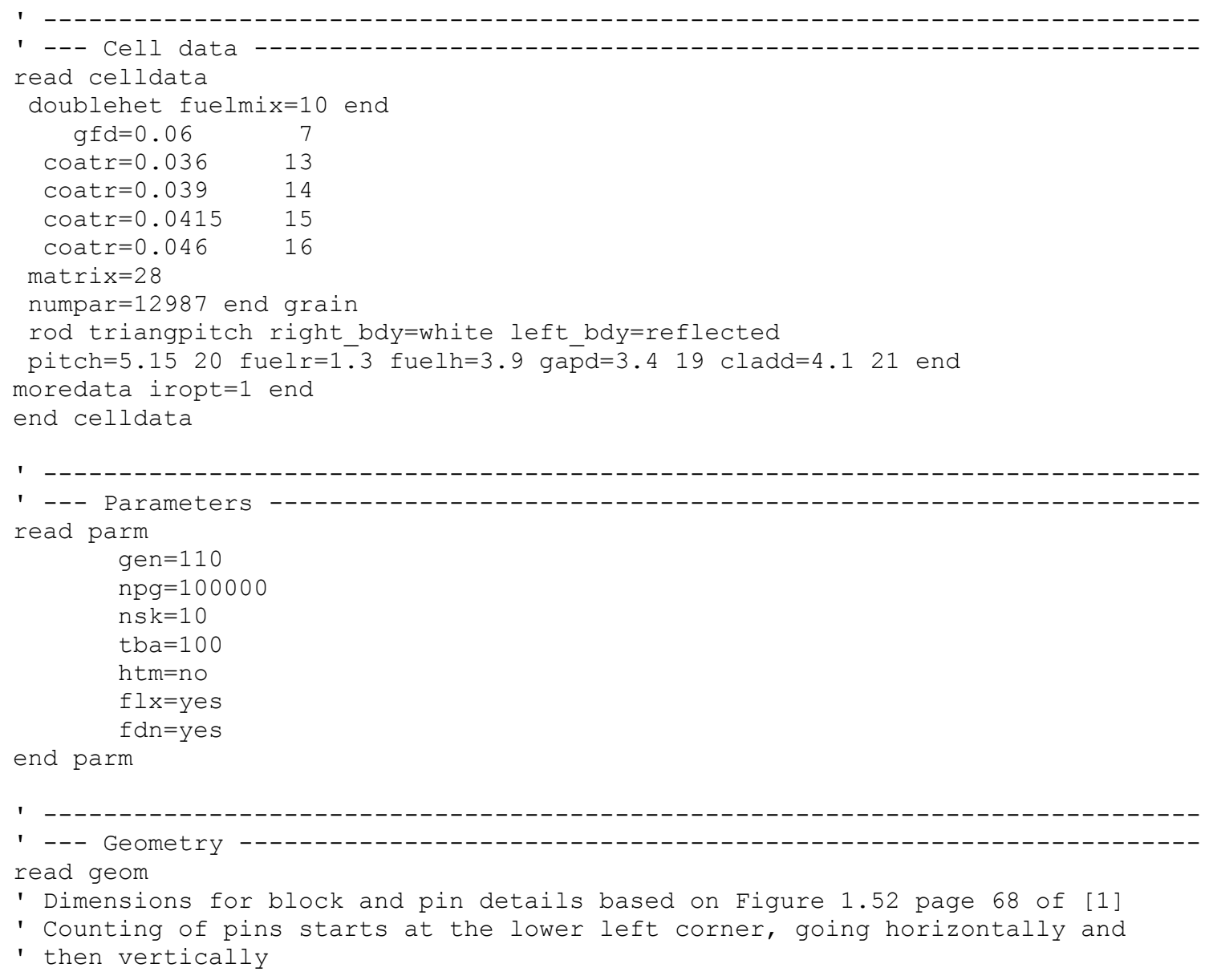




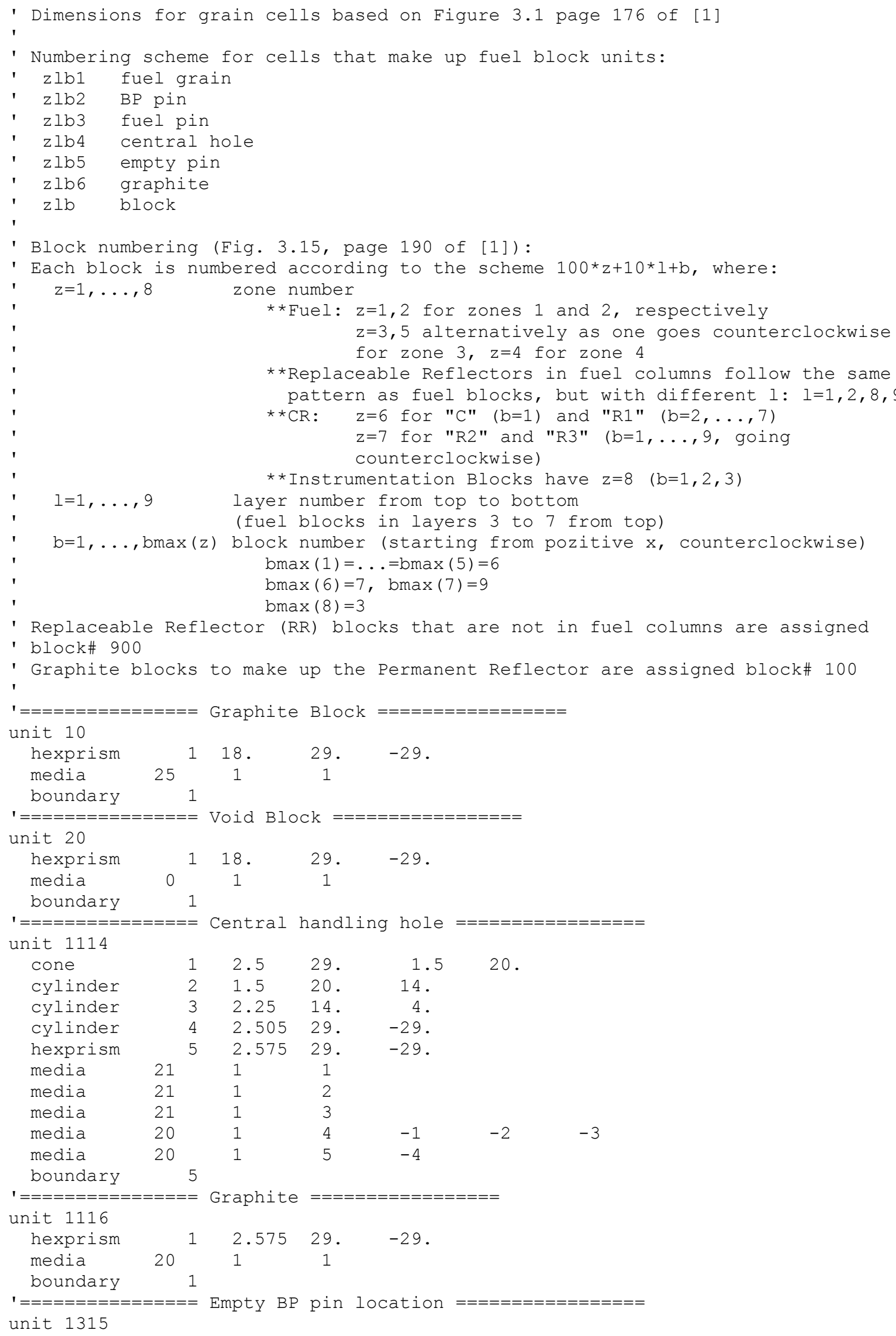




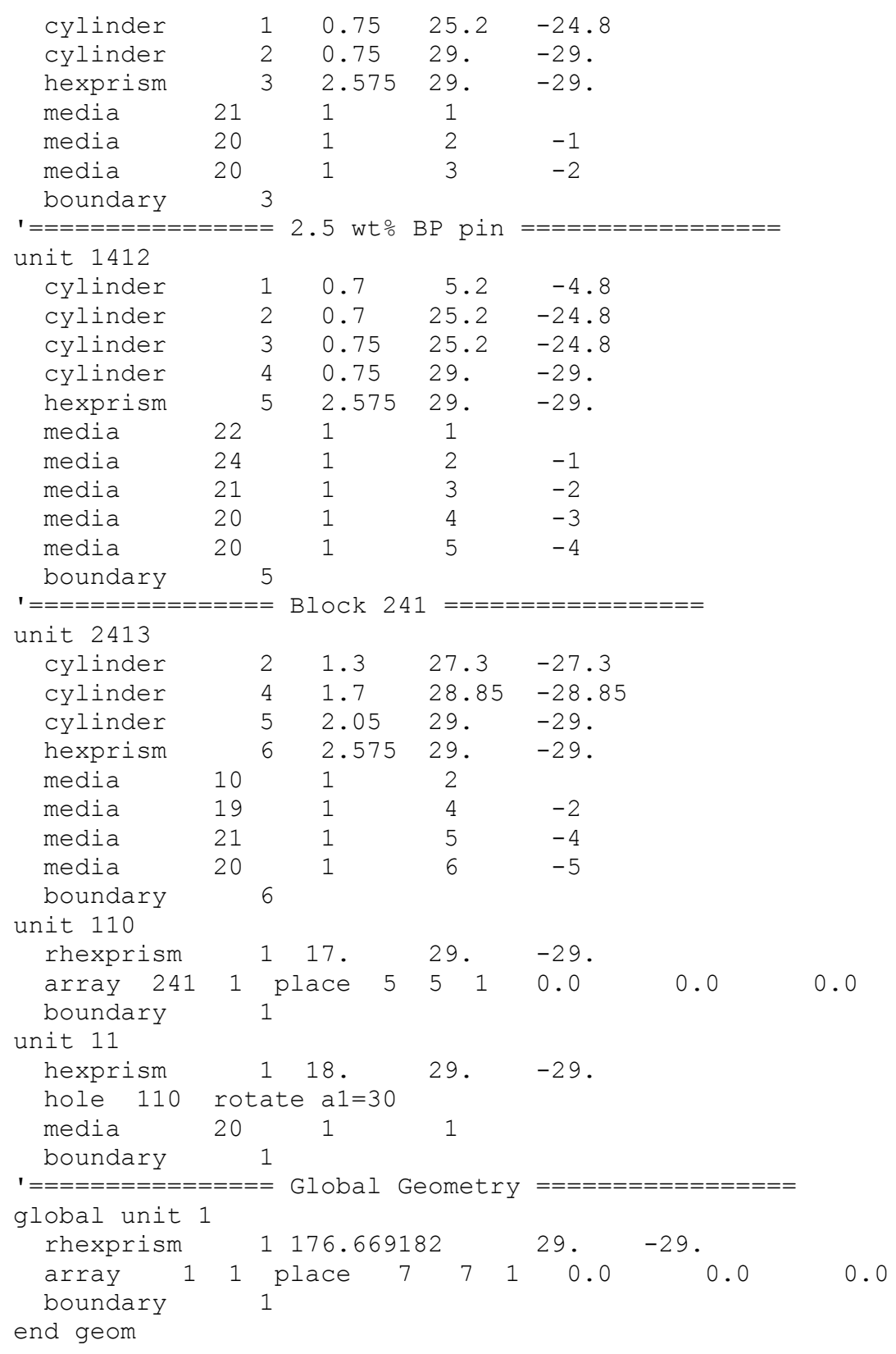

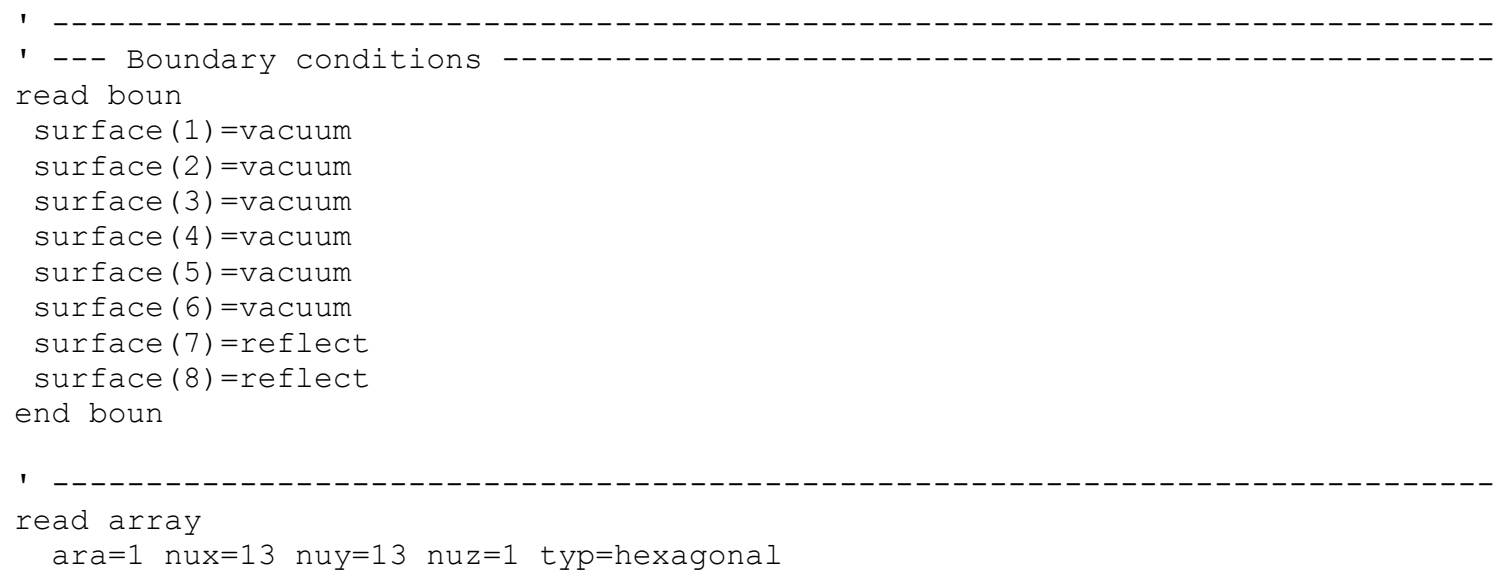




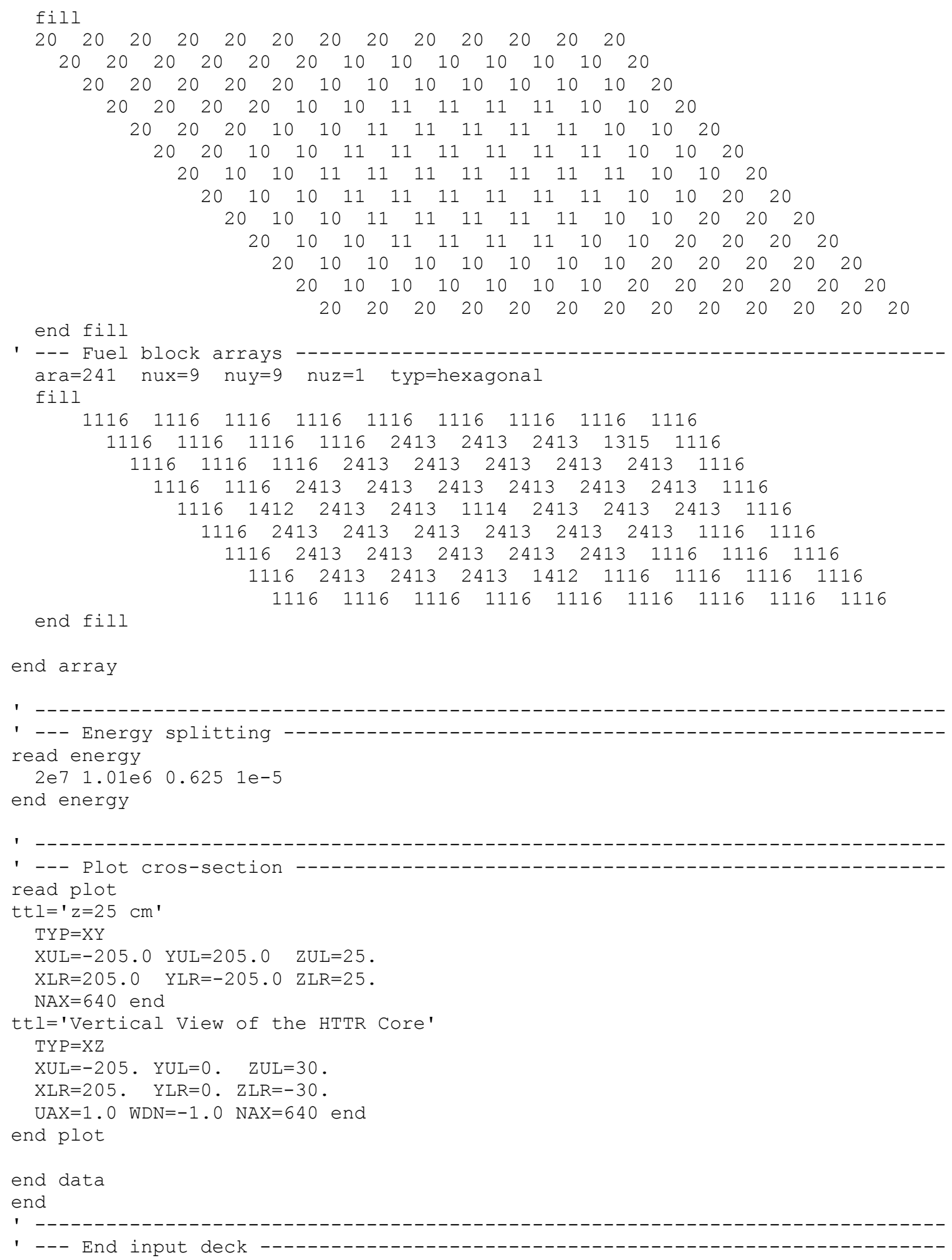





\section{APPENDIX E \\ SCHEMATIC DIAGRAMS OF THE HTTR BENCHMARK CASE}



Presented here is a schematic diagram of the HTTR benchmark case (Test2r3_Mg).
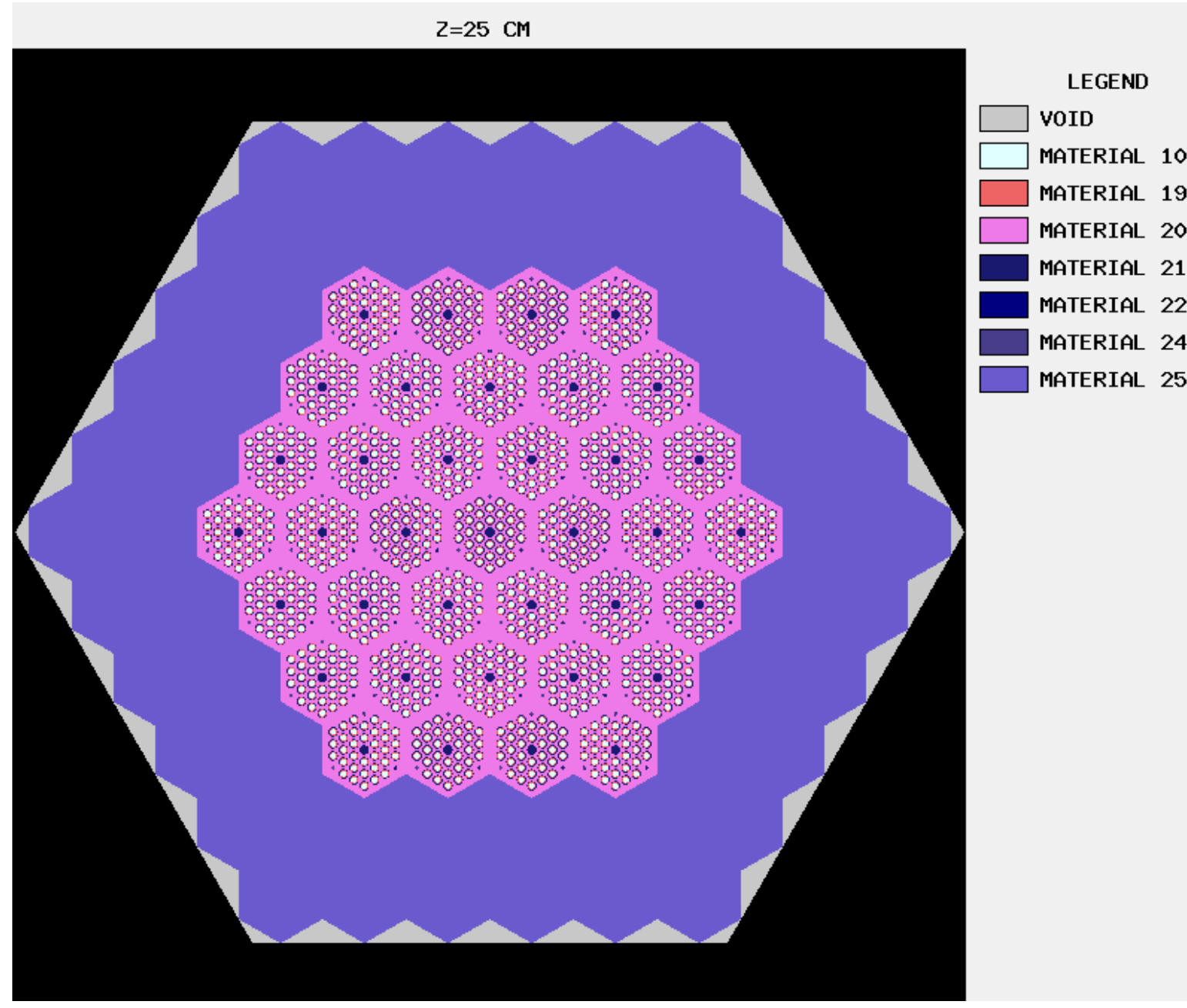

VERTICAL VIEW OF THE HTTR CORE

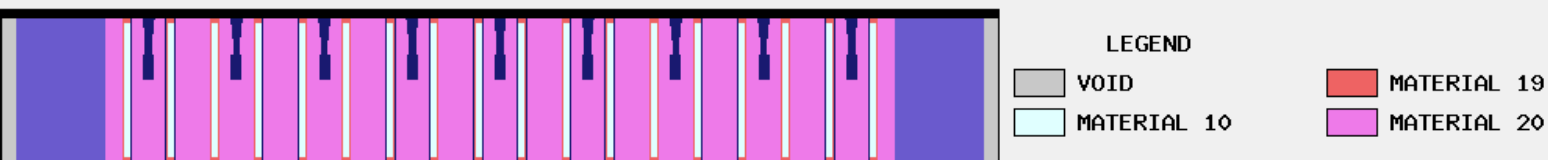





\section{APPENDIX F}

IR F-FACTOR 

Nuclides for which IR f-factors are applied

\begin{tabular}{|c|c|c|}
\hline Am-241 & $\mathrm{Np}-235$ & U-232 \\
\hline Am-242 & $\mathrm{Np}-236$ & U-233 \\
\hline$A m-242 m$ & $\mathrm{~Np}-237$ & U-234 \\
\hline Am-243 & $\mathrm{Np}-238$ & U-235 \\
\hline Am-244 & Np-239 & U-236 \\
\hline Am-244m & $\mathrm{Pa}-231$ & U-237 \\
\hline Bk-249 & $\mathrm{Pa}-232$ & U-238 \\
\hline Bk-250 & $\mathrm{Pa}-233$ & U-239 \\
\hline Cf-249 & $\mathrm{Pu}-236$ & U-240 \\
\hline Cf-250 & $\mathrm{Pu}-237$ & U-241 \\
\hline Cf-251 & $\mathrm{Pu}-238$ & \\
\hline Cf-252 & Pu-239 & \\
\hline Cf- 253 & $\mathrm{Pu}-240$ & \\
\hline Cf-254 & $\mathrm{Pu}-241$ & \\
\hline $\mathrm{Cm}-241$ & $\mathrm{Pu}-242$ & \\
\hline $\mathrm{Cm}-242$ & $\mathrm{Pu}-243$ & \\
\hline $\mathrm{Cm}-243$ & $\mathrm{Pu}-244$ & \\
\hline $\mathrm{Cm}-244$ & $\mathrm{Pu}-246$ & \\
\hline $\mathrm{Cm}-245$ & $\mathrm{Ra}-223$ & \\
\hline $\mathrm{Cm}-246$ & Ra-226 & \\
\hline $\mathrm{Cm}-247$ & Th-227 & \\
\hline $\mathrm{Cm}-248$ & Th-228 & \\
\hline $\mathrm{Cm}-249$ & Th-229 & \\
\hline $\mathrm{Cm}-250$ & Th-230 & \\
\hline Es-254 & Th-232 & \\
\hline Es-255 & Th-233 & \\
\hline Fm-255 & Th-234 & \\
\hline
\end{tabular}



NRC FORM $335 \quad$ U.S. NUCLEAR REGULATORY COMMISSION

$(12-2010)$

NRCMD 3.7

\section{BIBLIOGRAPHIC DATA SHEET}

(See instructions on the reverse)
1. REPORT NUMBER

(Assigned by NRC, Add Vol., Supp., Rev., and Addendum Numbers, if any.)
NUREG/CR-7106

2. TITLE AND SUBTITLE

Generation of a Broad-Group HTGR Library for Use with SCALE

5. $\operatorname{AUTHOR}(S)$

R. J. Ellis, D. J. Lee, D. Wiarda, M. L. Wiliams and U. Mertyurek

8. PERFORMING ORGANIZATION
provide name and mailing address.)

Oak Ridge National Laboratory

Managed by UT-Batelle, LLC

Oak Ridge, TN 37831-6170

9. SPONSORING ORGANIZATION - NAME AND ADDRESS (If NRC, type "Same as above"; if contractor, provide NRC Division, Office or Region, U.S. Nuclear Regulatory Commission, and mailing address.)

Division of Systems Analysis

Office of Nuclear Regulatory Research

US Nuclear Regualtory Commission

Washington, DC, 20555-0001

10. SUPPLEMENTARY NOTES

$\mathrm{n} / \mathrm{a}$

11. ABSTRACT (200 words or less)

With current and ongoing interest in high temperature gas reactors (HTGRs), the U. S. Nuclear Regulatory Commission (NRC) anticipates the need for nuclear data libraries appropriate for use in applications for modeling, assessing, and analyzing HTGR reactor physics and operating behavior. The objective of this work was to develop a broad-group library suitable for production analysis with SCALE for HTGR applications. Several interim libraries were generated from SCALE fine-group 238-group and 999-group libraries, and the final broad-group library was created from Evaluated Nuclear Data File/B Version and other codes. Furthermore, intermediate resonance (IR) methods were applied to the HTGR broad-group library, and lambda factors and f-factors were incorporated into the library's nuclear data files. A new version of the SCALE BONAMI module, named BONAMI-IR, was developed to process the IR data in the new library and, thus, eliminate the need for the CENTRM/PMC modules for resonance self-shielding. This report documents the development of the HTGR broad-group nuclear data library and the results of test and benchmark calculations using the new library with SCALE. The 81-group library is shown to model HTGR cases with similar accuracy to the SCALE 238-group library but with significantly faster computational times due to the reduced number of energy groups and the use of BONAMI-IR instead of BONAMI/CENTRM/PMC for resonance self-shielding calculations.
12. KEY WORDS/DESCRIPTORS (List words or phrases that will assist researchers in locating the report.)

HTGR, SCALE

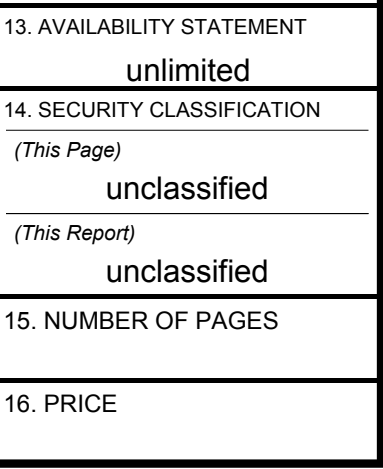






Printed
on recycled
paper

paper

Federal Recycling Program 








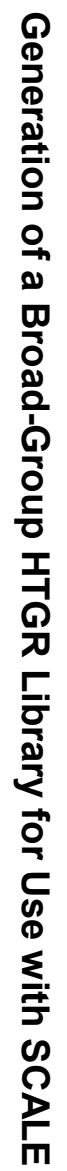

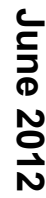

